UNIVERSIDADE DE SÃO PAULO

FACULDADE DE FILOSOFIA, LETRAS E CIÊNCIAS HUMANAS

DEPARTAMENTO DE FILOSOFIA

PROGRAMA DE PÓS-GRADUAÇÃO EM FILOSOFIA

\title{
A Unidade das Virtudes nos Diálogos Socráticos: uma questão de método
}

José Wilson da Silva

\begin{abstract}
Dissertação apresentada no Departamento de Filosofia da Faculdade de Filosofia, Letras e Ciências Humanas da USP para a obtenção do grau de Mestre em Filosofia, sob a orientação do Prof. Dr. Marco Antônio de Ávila Zingano.
\end{abstract}

São Paulo

2006 
UNIVERSIDADE DE SÃO PAULO

FACULDADE DE FILOSOFIA, LETRAS E CIÊNCIAS HUMANAS

DEPARTAMENTO DE FILOSOFIA

PROGRAMA DE PÓS-GRADUAÇÃO EM FILOSOFIA

\section{A Unidade das Virtudes nos Diálogos Socráticos: uma questão de método}

José Wilson da Silva

São Paulo

2006 
Para Pedro

In memoriam 


\begin{abstract}
Among the Socrates' theses found in the first Dialogues of Plato, there is one, about the unity of the virtues, which will concern us in our present research. More specifically, we will be interested in examining two ways of explaining the unity of virtues: the bicondicionality thesis and the identity thesis. We have found shortcomings in both theses. To avoid these shortcomings we propose as an interpretative hypothesis: the unity of the virtues thesis, in the Socratic Dialogues, is explained by the dialectical Platonic method. However, this affirmation has to deal with an alleged incompatibility between the Socratic elenctic method and the properly dialectical method, as it is developed in later Dialogues. So, we present two solutions to have a satisfactory final result for this research: 1) the two classic ways of explaining the unity of the virtues are part of a distinct thesis, the one based on dialectic, for dialectic implies the identity of virtues, which implies their inseparability and the difference of their parts; and 2) the elenctic method, a negative thesis, points to a positive one, that is, to the dialectical method.
\end{abstract}

KEY-WORDS: Plato, Socrates, Elenctic Method, Virtue, Knowledge, Dialectic Method. 


\section{Resumo}

Entre as teses do socratismo presentes nos primeiros Diálogos de Platão, é sobre a tese da unidade das virtudes que recaem nossos olhares nesta presente pesquisa e, particularmente, sobre as duas teses exegéticas acerca do estatuto desta unidade, a saber: a tese da bicondicionalidade e a tese da identidade. Encontramos, no desenvolver da pesquisa, insuficiências em ambas as teses. Por meio destas insuficiências chegamos a uma hipótese interpretativa: a tese da unidade das virtudes, nos diálogos socráticos, é iluminada pelo método dialético platônico. Porém, tal afirmação pressupõe uma incompatibilidade com o método socrático presente nestes Diálogos conhecido como método elênctico: ou temos o método elênctico ou o dialético. Logo, para que a pesquisa alcance um final satisfatório, apresentamos duas soluções: 1) as duas teses clássicas da unidade das virtudes fazem parte de uma terceira fundada na dialética, a dialética implica a identidade das virtudes que implica a sua inseparabilidade e a distinção entre as partes; e 2) o método elênctico, enquanto negativo que se encaminha para uma tese positiva, é um dos componentes do método dialético.

PALAVRAS-CHAVE: Platão, Sócrates, Método Elênctico, Virtude, Conhecimento, Método Dialético. 


\section{Índice}

$\begin{array}{ll}\text { Introdução } & 10\end{array}$

I. Exposição do Problema da Unidade das Virtudes nos Diálogos Socráticos 14

$\begin{array}{ll}\text { 1.Protágoras } & 14\end{array}$

1.1. Primeira parte do Diálogo: A especificidade das epist?mai 14

1.2. A Tese de Protágoras da Unidade das Virtudes $\quad 15$

1.3. Sócrates e o problema da unidade das virtudes: Os quatro 20 argumentos

1.3.1 O Primeiro argumento do Protágoras e o Eutífron 24

1.3.2. O Segundo argumento do Protágoras e o Carmides 26

1.3.3. O Terceiro argumento do Protágoras $\quad 27$

1.3.4. Quarto argumento do Protágoras e o Laches 28

2. Tese da Bicondicionalidade 33

2.1. Tese da Unidade 33

$\begin{array}{ll}\text { 2.2. Tese da Similaridade } & 34\end{array}$

2.3. Tese da Bicondicionalidade 36

2.3.1. As duas teses como momentos da Tese da Bicondicionalidade 37

2.3.1.1 Tese da Unidade Subsumida à Tese da Bicondicionalidade 38

2.3.1.2 Tese da Similaridade Subsumida à Tese da Bicondicionalidade $\quad 40$

3. Tese da Identidade $\quad 40$

$\begin{array}{ll}\text { 3.1. Penner } & 40\end{array}$

$\begin{array}{ll}\text { 3.2. Ferejohn } & 44\end{array}$

$\begin{array}{ll}\text { 3.3. Zingano } & 46\end{array}$ 
II. Mediações Necessárias Concernentes ao Paradoxo da Unidade das Virtudes

1. Definição socrática

1.1 Os critérios $\quad 52$

1.1.1 O critério "um-de-muitos"

1.1.2. O critério “o que X, ele mesmo, é” (X-ele-mesmo) 54

1.1.2.1. O uso das palavras eîdos, idéa ou Forma 55

1.1.2.2. O significado da palavra ousia (ser ou essência) 58

1.2. A prioridade epistemológica da definição $\quad 58$

1.2.1. Paradoxo da prioridade epistemológica da definição 59

1.2.2. A importância da prioridade epistemológica da definição 62

1.3. Crítica da questão o-que-é-X? 63

1.3.1. A imprecisão e as dificuldades da questão o-que-é-X? 64

1.4. tipos de definições $\quad 65$

1.4.1. Definição Verbal ou Lingüística 66

1.4.2. Definição Real $\quad 68$

2. Refutação

$\begin{array}{ll}\text { 2.1. Considerações Preliminares } & 71\end{array}$

$\begin{array}{ll}\text { 2.2. Silogismo } & 72\end{array}$

2.3. Refutação Direta e Refutação Indireta 75 
2.3.2. Refutar uma tese diretamente 76

2.4. Epagoge $\quad 76$

$\begin{array}{ll}\text { 2.5. Método Elênctico } & 78\end{array}$

2.5.1. A Proferição Socrática da Falta de Conhecimento 81

2.5.2. Problemas acerca do Critério de Verdade na Investigação 87 Socrática

2.5.3. Contra o coerentismo com base em endoxa 90

$\begin{array}{lr}\text { III. Conclusão } & 128\end{array}$

$\begin{array}{ll}\text { 1. Por que negar o Método Elênctico? } & 128\end{array}$

$\begin{array}{ll}\text { 2. Por que nenhuma das teses Satisfaz? } & 140\end{array}$

$\begin{array}{lr}\text { 3.Dialética } & 147\end{array}$

$\begin{array}{ll}\text { IV. Bibliografia } & 156\end{array}$ 


\section{Agradecimentos}

Meu mestrado foi obra de muitas mãos. Agradeço a todos os meus. Neste momento me reservo a agradecer aos que me estenderam as suas. Por isso agradeço a:

Emiliano (pelos vagalumes e pelas letrinhas M.C.);

Patrick, "Shueize", (meu grande amigo, leitor dos meus textos e, muitas vezes, rabujento que amo tanto);

Rosanna Mota, Galba Veras e família (Lia, Lívia e Raul), a quem sou extrema e eternamente grato por "todas as coisas";

D. Rita (minha mãe), Aretusa (Tutu), Jorda e Valeska, por me darem família e lar;

Igor, meu novo amigo, e Daniel (Dan) pela imensa ajuda;

Aos professores José Carlos Estêvão e Roberto Bolzani Filho que compuseram a banca de qualificação e cujas críticas e sugestões foram definitivas para uma melhora substancial das idéias, elaboração e adornamento deste trabalho.

Ao Prof. Dr. Marco Zingano, pela orientação gentil, inteligente e, acima de tudo, paciente. Agradeço por ter acreditado.

Aos meus anjos da guarda da Secrataria do Departamento de Filosofia da USP. Agradeço pela gratuidade do gesto a: Geni e Lu (minhas companheiras de bom dia), Maria Helena (minha guia), Verônica (pela gentileza e o presente) e, principalmente, Marie (por tudo e mais um pouco).

A FAPESP, pela bolsa de mestrado concedida. 


\section{Introdução}

Grande parte dos come ntadores associam as teses apresentadas nos primeiros escritos platônicos às teses do Sócrates histórico - estes primeiros escritos nada seriam do que a reprodução platônica do pensamento socrático. Segundo estes comentadores, a diferença marcante entre estes dois filósofos estaria na teoria platônica das Idéias inteligíveis e o que ela carrega consigo. Por conseguinte, além da "Teoria das Idéias" outras doutrinas e o método empregado por Platão a partir dos Diálogos intermediários, o método dialético, que está intimamente ligados a esta teoria, marcariam esta diferença. Assim sendo, como não está presente nos primeiros Diálogos uma discussão metódica das Idéias inteligíveis, não está presente, conseqüentemente, as doutrinas e seu método dialético.

Porém, existe um método empregado neste primeiros Diálogos que ficou associado a Sócrates e que ficou conhecido como método elênctico. Método refutativo que correspondeu, de forma apropriada, à sua proferição da falta de conhecimento. Sócrates sempre dizia não ter o conhecimento das matérias que interrogava, o que o forçava a questionar os outros que se diziam sábios em tais assuntos através deste método, na maior parte das vezes refutando-os. Outro fator preponderante na associação deste método aos primeiros escritos é a característica aporética destas obras. Os Diálogos que se propuseram a definir um determinado assunto atingiam um fim incompleto, uma dificuldade que impossibilitava a investigação de prosseguir, isto é,

uma aporia. A função do método empregado por Sócrates apenas verificaria a capacidade dos seus interlocutores em defender suas teses. Excluindo com isto o objetivo de atingir um fim positivo. Esta é uma das diferenças deste método dos 
primeiros escritos com o método dialético platônico, que tem a finalidade de alcançar um fim positivo.

Nossa hipótese é que esta dialética (platônica) encontra-se nestes primeiros escritos. Além disso, ela não está, em absoluto, apresentada de forma completa como aquela exposta nos Diálogos posteriores. Mas em essência é a mesma. O princípio desta dialética é a identidade, e esta identidade é a essência da coisa investigada por Sócrates e seus companheiros. Ela é alcançada pela aquisição do "mesmo", do "idêntico" ou do "um-de-muitos" presente nas múltiplas coisas que compõe uma classe comum. A identidade, que é o fim da investigação socrática, é adquirida por um processo negativo incluso na pesquisa. Os pressupostos, que são o ponto de partida da investigação, são examinados; no mais das vezes, eles são apresentados como insuficientes. Tais pressupostos, por ter esta determinação de insuficiência, são refutados com o objetivo de se alcançar uma tese mais precisa e universal possível. Assim, na estrutura dialógica, a investigação parte de pressupostos, que tem por base as coisas múltiplas acima indicadas, encaminhando-se para uma tese universal que abranja todos os casos particulares.

Valendo-se destas considerações anteriores e transportando-as para as relações entre as virtudes, observamos que esta relação apresenta-se de duas formas e que obedece a uma mesma regra: universalparticular. A primeira forma é entre os casos particulares das virtudes e a virtude que corresponde a estes casos, por exemplo, a coragem diante dos perigos do mar e durante uma batalha são casos particulares do universal Coragem, o mesmo vale para todas as outras virtudes. A segunda forma encontra-se nas relações entre os universais, a Sabedoria, Justiça, Piedade, Temperança e Coragem são casos particulares do universal Virtude. Mesmo estas virtudes sendo universais, diante da Virtude que é mais universal, se comportam como casos 
particulares deste. É esta relação que pretendemos, na pesquisa, indicar como possível solução para o chamado Paradoxo da Unidade das virtudes.

Um outro indício que nos estimulou a chegar a essa hipótese foram as insuficiências das teses que apresentam suas soluções para este paradoxo: a Tese da Bicondiconalidade e a Tese da Identidade. Da primeira aceitamos a tese de que as virtudes estão em uma relação bicondicional, tendo uma se tem todas, porém, esta tese está fundada em um relação linguiística, o que deixa de lado o ponto forte que sustenta a relação entre as partes da virtude e a Virtude toda inteira, isto é, uma relação essencial (quanto ao tipo de relação essencial, isto será discutido no desenvolver do texto). Da segunda aceitamos que a busca de Sócrates é pela identidade, porém, não aceitamos a dissolução das diferenças entre as virtudes. Para fugir a esta objeção alguns defensores apresentam que a diferença é dada pelos domínios em que esta "unidade" - que é identificada com o "conhecimento do bem e do mal" - é aplicada. Mas mesmo esta saída contém seus problemas e tecemos objeções quanto a esta interpretação que denominamos de diferença contigente.

Nossa hipótese é que o método dialético comporta em si o método elênctico, como um momento deste, e que ilumina o paradoxo da unidade das virtudes. Assim como, consideramos alguns elementos das teses que interpretam este paradoxo como partes integrantes da tese que defendemos. Nossa pesquisa, porém, visa apenas uma indicação desta interpretação. Temos somente o objetivo de indicar tais insuficiências do que apresentar soluções. Dividimos o texto em três partes: a primeira é a exposição dos problemas que a questão das unidades das virtudes acarretam. Além de apresentar uma dificuldade interna a sua própria estrutura, ela também apresenta incompatibilidade entre os Diálogos. Tais como a tese que é a apresentada no Protágoras e o que é discutido no Laches, Eutífron e Carmides. Consideramos que a tese fundada na dialética 
platônica justifica todas as aparentes incompatibilidades. A segunda parte é uma mediação necessária para se chegar à terceira parte, em que tentamos demonstrar quais os objetivos de Sócrates nestes primeiros Diálogos e o que significa o seu método. A terceira parte é a nossa conclusão, onde apresentamos as insuficiências do método elênctico e das teses e apontamos a nossa hipótese como uma possível solução para o paradoxo da unidade das virtudes. 


\section{Exposição do Problema da Unidade das Virtudes nos}

\section{Diálogos Socráticos}

\section{Protágoras}

\subsection{Primeira parte do Diálogo: A especificidade das epist?mai}

O Protágoras é um Diálogo que apresenta três concepções rivais concernentes à educação e à virtude, a saber: a concepção sofística; a da tradição poética; e por último, a concepção socrática da virtude-conhecimento. Em nossa análise do Protágoras, o que nos interessa investigar é este terceiro item, exatamente, da virtudeconhecimento. Nosso recorte inciderá na questão que ficou conhecida como o Paradoxo da Unidade da Virtude. Isto é deixado transparecer, no início do Diálogo, quando Sócrates, de antemão, já indica qual a sua posição e sua preocupação, ao principiar a discussão com Hipócrates, chamando a atenção para a importância da Sabedoria. Nas páginas Stephanus que compreendem 310b/314c, nas quais Sócrates interroga Hipócrates com o objetivo de sondar se ele está a par das consequiências de aprender os ensinamentos de Protágoras, vemos que ele já estabelece a necessidade de se buscar a especificidade do conhecimento que deve ser aprendido para se tornar melhor. Ter este conhecimento possibilita, a quem desejar, transmitir e, portanto, tornar os outros virtuosos. Se este que transmite sabe transmitir é porque tem o conhecimento da coisa a ser transmitida; assim como, os meios para transmitir tal coisa. Já que é a virtude que torna os outros virtuosos, e Sócrates nos indica que a virtude é uma espécie de conhecimento, logo, a educação dos melhores deve visar o ensino da virtude. 


\subsection{A Tese de Protágoras da Unidade das Virtudes}

Se Protágoras declara ter algum conhecimento sobre o ensino da virtude, Sócrates irá examiná-lo para saber se diz algo de coerente, já que ele mesmo suscita duas dúvidas que o fazem perder a confiança no ensino da virtude chegando, até mesmo, a ter dúvidas do ensino desta. É claro, estamos expressando a sua posição no início do Diálogo, da qua.l se diferencia da que ele apresenta na parte final deste. Protágoras se considera como um especialista em tornar os homens melhores, então, ele deve ter o conhecimento desta coisa que torna os homens melhores. Seus ensinamentos têm por objetivo a boa deliberação, seja sobre os assuntos privados, como administrar a casa da melhor maneira, seja sobre os assuntos da cidade, como conduzir as resoluções relativas à administração da cidade, sabendo conduzi-los com perfeição tanto pelos atos quanto pelas palavras. O objeto de ensino que Protágoras trata, nesta passagem, não é o conhecimento técnico, mas sim o conhecimento moral.

Sócrates, valendo-se desta resposta de Protágoras, induz que este objeto de ensino que está relacionado à administração da casa e da cidade é, portanto, a "arte política”, tecnh pol it ikh, A questão que surge dessa resposta de Protágoras é: a política pode ser ensinada? Deste ponto, Sócrates apresenta as suas duas objeções ao ensino da virtude (319b-320c). Valendo-se destas objeções, Protágoras inicia um longo discurso para tentar responder a elas. Após o longo discurso de Protágoras, Sócrates prende a sua atenção a nenhum outro elemento do discurso de Protágoras senão a tese que este suscita. Para a solução do problema posto por Sócrates - se a tecnh politikh, pode ser ensinada - Protágoras defende a tese do conhecimento da única coisa na qual todos os cidadãos devem ter participação: "acaso existe uma unidade ou não, a qual todos os 
cidadãos devem participar, para que a existência da cidade seja possível?" poter on estin ti eh h. Ouk estin ou-amankaion pantaj touj politaj metecein, eiper mellei polij ei fai, 324e). Como Protágoras ressalta, esta coisa única, ou melhor, esta "unidade", eṇ, não pode ser a arte do carpinteiro, nem do escultor, nem de nenhuma destas espécies de coisas, ou seja, esta unidade não é, nem pode ser a sabedoria técnica, mas sim as virtudes, como a justiça, a temperança, a piedade e, "em geral", diz Protágoras, “a própria unidade ên autva] nomeio ser a virtude do homem androj avethn]" (325a). Protágoras considera que a virtude deve ser adquirida como uma unidade.

Aqui damos início a uma tese que sempre é deixada de lado pela maior parte dos comentadores. Tomamo-la como peça de grande importância na elucidação da questão. Esta é a tese apresentada por Protágoras em seu próprio discurso. Desta forma, antes de entrarmos na exposição das teses clássicas da unidade das virtudes, vamos tratar da tese de Protágoras. Sua importância é considerada, mormente pelo fato de que é valendo-se do discurso de Protágoras que Sócrates elabora as questões que serão suscitadas no diálogo.

Porém, como se dá esta unidade para Protágoras? É exatamente o que a seguinte exposição pretende responder, já que é a forma que o próprio Protágoras utilizou para dar a resposta a Sócrates. É na demonstração de como os homens tornamse virtuosos que ele apresenta sua própria tese da unidade. Como ele mesmo explica, a formação dos homens, que tem por objetivo torná-los melhor, deve ser iniciada a partir da infância e todas as lições e exortações devem continuar por toda a vida, constituindo um aprendizado e uma prática constante visando à virtude - virtude pensada neste caso como unidade, daí por que o objetivo da formação dos jovens deve ter como meta alcançar esta "virtude-unidade". Desta forma, a educação dos cidadãos percorre diversas 
fases que nomearemos de núcleos paidêuticos. Estes núcleos se distribuem da seguinte forma:

1) o núcleo familiar;

2) o núcleo escolar que compreende três fases: o aprendizado das letras, o aprendizado da música e a ginástica;

3) e a pólis, sendo o último destes núcleos.

Então, desde criança o homem recebe lições do que é o bem ou o mal, belo ou feio, justo ou injusto etc. e através da linguagem e da coação, ele é forçado a praticar estas lições, seja pelo pai, pela mãe ou pela ama, inicialmente na família, ou se preferirmos no núcleo paidêutico familiar. Depois disso, a criança é levada para a escola onde, através da imitação (mi mhsij) do conteúdo ético presente na obra dos grandes poetas, é forçada a aprender de cor esses poemas com o objetivo de despertar nelas o desejo de ser como esses heróis. Aqui, nos encontramos na primeira fase do segundo núcleo paidêutico. Através destas lições, a criança começa a desenvolver sua capacidade de raciocínio para poder discernir como deve conduzir sua vida, ou seja, ela começa a desenvolver sua "capacidade reflexiva" (dianoia). A dianoia, "faculdade de refletir", sempre está associada, conforme os grandes filósofos da antigüidade, a uma idéia de atividade reflexiva relacionada com a práxis, prakij, e que exprime a idéia de previdência, precaução. Temos, portanto, que uma educação que tem a finalidade de desenvolver a virtude nos homens deve ter como prioridade desenvolver esta capacidade reflexiva, sua capacidade de tomar decisões acertadas. Então, inicialmente, através da linguage m e da coação, se desenvolve na criança esta capacidade reflexiva, a dianoia; em seguida, a criança aprende música, sendo esta a segunda fase do segundo núcleo paidêutico; depois ginástica, com intenção de desenvolver um corpo são a 
serviço da dianoia, - esta é a terceira fase do segundo núcleo paidêutico. Por fim, a cidade, através das leis, obriga o jovem a obedecê-las.

Protágoras formula esta divisão em núcleos paidêuticos atentando para a importância da linguagem para a experiência grega das assembléias. Ele sabe que uma boa formação deve estar direcionada para este ponto essencial, uma vida social que se quer perfeita. Dois são os motivos: primeiro, porque o conhecimento moral só pode ser transmitido pela linguagem; segundo, o bem-viver e o bem-agir dependem do modo como esta linguagem é utilizada (no caso das assembléias, a melhor forma de se produzir belos discursos em vista do bem necessário para a vida particular e, notadamente, comunitária). Com isso, estes núcleos citados por Protágoras têm por objetivo o desenvolvimento de virtudes específicas. Quando se inicia o ensinamento das crianças para a prática da virtude na família, de início, para desenvolver sua capacidade reflexiva, podemos considerar que as virtudes que serão desenvolvidas são a "Sabedoria", s of ia, e a "Prudência", f ronhsij. Na escola, estas virtudes que foram desenvolvidas anteriormente são reforçadas e é desenvolvida, através da música, a “Temperança", swfrosunh, e, através da ginástica, se desenvolve a "Coragem", a ndr ei a"; após a escola, o jovem desenvolve a "Justiça", dikaiosunh, por meio das leis impostas pela cidade.

O que Protágoras tem em vista é que a educação que é iniciada a partir do núcleo paidêutico familiar, que passa pela escola e chega na cidade, tem em vista a prática unitária da virtude, ou seja, tornar os homens inteiramente virtuosos. Mas como deve ser entendida esta unidade das virtudes sugerida por Protágoras? Em primeiro lugar, as virtudes serão desenvolvidas nos jovens desde a sua infância até a sua vida adulta. Para cada fase, uma correspondente virtude. Ao final de toda esta trajetória, todas as virtudes consideradas como as mais importantes terão sido incorporadas pelos 
jovens. Logo, podemos entender que é possível falar de uma unidade, se ela for compreendida da seguinte forma:

A unidade da virtude $=\{$ Sabedoria e/ou Temperança e/ou Coragem e/ou Justiça\}.

A tese da unidade protagoriana é que esta Virtude seria uma espécie de conjunto de todas as outras virtudes, com uma natureza peculiar: permite ao agente ser sábio sem ser justo, agir corajosamente sem a necessidade de agir conforme as outras virtudes - o que concorda com a sua opinião expressa em 329e e 349d. Aqui, não existe nenhuma relação lógica ou ontológica que garanta esta unidade. Tudo parte de um princípio empírico da educação mediada pela linguagem e pela coação, princípio que está presente em todo o discurso de Protágoras sobre o ensino da virtude.

Com isso, temos a tese de Protágoras, para quem a unidade das virtudes deve consistir na possibilidade de que seus elementos não necessitem de qualquer relação pré-estabelecida para garantir esta unidade. Na vida adulta o jovem terá alcançado a virtude como um todo, pois ao longo de sua vida elas foram introjetadas em sua alma. A unidade aqui é entendida como um todo de partes completamente distintas sem nenhuma interrelação entre as partes, uma unidade construída pela paidéia. Cada parte tem sua própria capacidade, diferenciando-se cada uma da outra e da própria virtude como um todo. O que não conflitaria com o seu posicionamento em $330 \mathrm{~b}$ onde ele afirma que cada virtude tem sua capacidade, dýnamis, própria. Valendo-se deste discurso de Protágoras, é que Sócrates elabora suas questões com o objetivo de esclarecer que tipo de unidade é esta. 


\subsection{Sócrates e o problema da unidade das virtudes: Os quatro argumentos}

Sócrates se volta exatamente para o cerne da questão proposta por Protágoras: a unidade que deve regulamentar todo o agir humano. Sócrates lembra que, para Protágoras, todas as virtudes formam uma unidade: a justiça, a temperança, a piedade, e todas estas coisas em geral seriam uma única coisa, a virtude (Cf. Prot. 324e.). Com base nisto, Sócrates formula a sua pergunta: "qual dessas duas hipóteses: a virtude é uma unidade, na qual a justiça, a temperança, a piedade são partes [mo r i a ] dela, ou estas coisas que mencionei, todas são nomes [panta onomata] de um único e mesmo ser [toul autou/ enoj ontoj]?" (329 c). Sócrates continua tocando na mesma tecla: ele quer o específico das coisas que são tratadas. É preciso que Protágoras especifique que unidade é esta, pois através disso pode-se determinar com maior precisão quais as conseqüências para a vida do homem, valendo-se, o encaminhamento das suas ações, desta "coisa única". Consoante com a pergunta de Sócrates (329c-d), temos duas teses a examinar:

A. A virtude é uma "unidade" (eh ) compostas de "partes" (no r i a): Justiça, Temperança, Piedade etc.;

$\mathrm{Ou}$

B. Todas as virtudes são uma única e mesma coisa (tou/a ut ou/ en oj on toj), diferenciando-se umas das outras somente pelos nomes ( 0 n 0 mat a).

Nessas duas primeiras teses, temos uma concepção de unidade que mantém a diferença (a) e uma outra, a da unidade que dissolve a diferença (0). A posição de Protágoras é aquela apresentada na primeira fórmula: “é um único ser [enoj ont oj ], e as 
virtudes que me perguntaste são suas partes [mo r i a ]" (329 d). Desta opção de Protágoras temos mais duas alternativas:

C. Suas partes são da mesma maneira que as partes do rosto como a boca, nariz, os olhos e as orelhas;

$\mathrm{ou}$

D. São como pepitas de ouro, que não diferem umas das outras, e cada uma do todo, a não ser pelo tamanho ou pela pequenez.

Conforme a imagem sugerida por Sócrates, as partes das virtudes não seriam para Protágoras como pepitas de ouro, indiferenciadas, mas partes distintas de um mesmo todo como o nariz, a boca, os olhos os são de um rosto. Protágoras sustenta esta posição.

Se para a existência das cidades é necessária a virtude, compreendida como unidade, então Sócrates pergunta se todos os cidadãos teriam participação nesta virtude ou se apenas algumas das partes da virtude pertenceriam a alguns deles; ou melhor, seria possível a alguém possuir todas as virtudes ou isso não é possível, de modo que um indivíduo que é justo não é necessariamente sábio e assim por diante? O que parece contraditório na fala de Protágoras é que todos os cidadãos imersos na prática da virtude, pelo hábito de praticá-las e pela coerção que a cidade exerce, devem ao final de sua formação possuir todas as virtudes, no entanto, ele assume que nem todos os homens possuem todas elas. Ou seja, ao final do processo de formação do jovem, este teria a virtude como um todo (ele teria todas as virtudes: a Sabedoria, Justiça, Piedade, Temperança e a Coragem), mas, ao mesmo tempo, este jovem, que passou por esta formação, pode carecer de algumas delas. 
Podemos notar no Diálogo que a segunda tese ficou suspensa e os argumentos se voltaram para a primeira. Por conseqüência, hipoteticamente temos, até este momento, as seguintes considerações: 1) a virtude é uma unidade (ou um todo) e as outras virtudes são suas partes; 2) cada parte se difere de cada outra por si mesma e por sua propriedade [dunami j]. Com isso, é necessário esclarecer um ponto: se estas virtudes fariam parte de um todo e, ao mesmo tempo, seriam diferentes umas das outras. A questão, então, é a seguinte: se elas fazem parte de um todo, deve existir necessariamente um ponto em comum entre elas, deve existir um caráter distintivo comum a cada uma delas que podemos considerar como evidência de sua própria identidade. Dito de outro modo, as alternativas que Sócrates apresenta são:

a) As virtudes são uma única coisa;

$\mathrm{Ou}$

b) Existe alguma coisa que é comum a todas elas e que, por isso mesmo, lhes permite serem reunidas em uma unidade.

De acordo com a tese de Protágoras, as virtudes são adquiridas ao longo da vida do indivíduo até que elas formem um todo único. Este todo, que foi nomeado como a "virtude do homem", não depende de relações lógicas, essenciais, nem mesmo ontológicas para que ele se efetue. Todas as virtudes são diferentes e ao mesmo tempo compõem uma unidade (não fundada em semelhanças ou identidades); todas são completamente distintas e, assim mesmo, constituem uma unidade adquirida pelo hábito através do ensino, da mimese e/ou da coação. Tendo em vista essas características da unidade protagoriana, a seguinte conclusão socrática surge como uma indagação: "por acaso, nenhuma outra parte da virtude é tal qual a ciência, nem tal qual a Justiça, nem tal qual a Coragem, nem tal qual a Temperança, nem tal qual a Piedade?" (0 uden ar a 
estin twh thi arethi moriwn allo oion episthmh, oudV oion dikaiosunh, oudV oion andreia, oudV oion swfrosunh, oudV oi on ośiothj, 330b). Se as coisas processam-se desta forma, é necessário, como diz Sócrates, que "procuremos o que existe em comum em cada uma delas". ${ }^{1}$ É preciso determinar o que existe de idêntico entre as virtudes, e permite que elas sejam reunidas em uma única coisa. A partir deste momento, a investigação visa a encontrar estes pontos comuns (koinh) entre as virtudes, estabelecendo relações entre elas através dos quatro principais argumentos apresentados no Protágoras para esta questão: primeiro, a relação entre a Justiça e a Piedade (330c332a); segundo, entre a Sabedoria e a Temperança (332a-333c); depois, entre a Justiça e a Temperança (333c-334c); e, por fim, entre a Coragem e a Sabedoria (349b-361a). Analisaremos cada um destes argumentos junto com os problemas que os outros Diálogos socráticos suscitam. Para o primeiro argumento, confrontaremos esta passagem do Protágoras com as relações entre Justiça e Piedade no Eutífron. Para o segundo argumento, analisaremos as conclusões do Carmides sobre a relação entre Temperança e Sabedoria e as que são suscitadas no Protágoras. Deixaremos de lado o terceiro argumento porque não apresentar nenhuma relação fundamentada ente a Temperança e Justiça que nos permita chegar a qualquer conclusão, assim como não temos nenhum Diálogo que estabeleça esta relação. Para o último, trataremos da questão mais polêmica do paradoxo da unidade da virtude lançando mão das questões suscitadas no Laches.

1 koinhl skeywmeqa poibn ti autwh estin ekaston [330b]. Ao contrário do que se traduz habitualmente, chamando a atenção para a expressão poi hn ti , consideramos que o que realmente está sendo colocado em jogo é a necessidade de se estabelecer o que é esta coisa comum a todas as virtudes. Podemos até admitir que a expressão poi hn ti tenha a sua importância, mas não é ela que demarca com precisão o que Platão está aspirando. É o termokoi nh, que demarca precisamente esta aspiração. 


\subsubsection{O Primeiro argumento do Protágoras e o Eutífron}

Na relação entre a justiça e a piedade, Sócrates já considera um elemento: a justiça, dikaiosunh, é uma espécie de pragma ${ }^{2}$ e ela é "em si mesma" (auth)) uma coisa justa; do mesmo modo, a piedade é uma pragma e é "em si mesma" piedosa. Logo, existe uma semelhança entre a piedade e a justiça, ambas são pr a g mat a e a uth, Elas são neste próprio em si idênticas a si mesmas, logo, distintas. A justiça e a piedade são pragmata, cada uma sendo "em si mesma", respectivamente, justa e pia, de forma que não é da natureza da justiça ser uma coisa piedosa, mas sim justa, e não é da natureza da piedade ser justa, mas sim pia. O mesmo critério se aplica também para a piedade. Encontramos aqui, exposto de uma outra forma, a mesma questão que foi estabelecida no início do Protágoras: os resultados de uma ação enquanto produtos das episth ma i e das teçnai. O específico de uma episthmh ou de uma teçnh só é capaz de produzir ou ter como resultado este mesmo específico, ou seja, o específico da pintura só pode ser capaz de produzir imagens pintadas, o específico da medicina só tem como resultado a saúde, da mesma forma, o específico da justiça só pode produzir a mesma essência da justiça, a ação justa. Não é da própria natureza da justiça produzir o seu contrário ou outro produto que não compartilhe desta essência.

Essa identidade, "em si mesma", de cada virtude não significa que a justiça, por não ser a mesma coisa que a piedade, seja seu contrário: a impiedade, isto é, não significa que a natureza própria da justiça seja, necessariamente, o contrário da natureza própria da piedade. Não ser justo não resulta em ser piedoso, nem impiedoso, assim como não resulta em ser sábio etc. No entanto, podemos afirmar que a justiça é uma

${ }^{2}$ É desta forma que está expresso no original grego: h’ dikaiosunh prágma, ti, egtin ho. ouden pragma* $[$ Prot.330c]. 
coisa pia e a piedade é uma coisa justa. Este elemento comum parece ser a pedra de toque para a solução deste impasse. Como ambas possuem este elemento que lhes permite a semelhança, pode-se afirmar que a justiça é piedosa e que a piedade é justa. Sócrates conclui, precisamente, afirmando que ou a justiça e a piedade são uma única e mesma coisa ou são "muito semelhantes", omoi otaton (331 b). Com isso, voltamos a insistir que a unidade entre as virtudes - a qual Protágoras mencionou primeiro - só pode ser estabelecida diante das alternativas anteriormente elaboradas por Sócrates: a) ou porque elas possuem características comuns; b) ou porque todas são uma única e mesma coisa.

Tomando por base a discussão acerca da unidade das virtudes no Protágoras, em particular a relação que ali é estabelecida entre a justiça e a piedade, recorremos ao Eutífron para verificar como esta mesma questão é ali tratada. Tomá-lo-emos como auxílio, de forma a nos propiciar uma elucidação em nossa investigação acerca da unidade das virtudes. Examinaremos uma questão que justifica o auxílio do Eutífron, a saber, a relação entre justiça e piedade que, tal como é apresentada nele, se diferencia da que é apresentada no Protágoras, já que no Eutífron a piedade é uma parte da virtude, enquanto no Protágoras a justiça pode ser piedosa e a piedade pode ser justa.

Nisto, duas questões precisam ser resolvidas: 1) Como determinar a unidade das virtudes, quando a especificidade de cada virtude determina o seu em-si, a uth, e, ao mesmo tempo, podemos fazer declarações do tipo "a Justiça é pia" e "a Piedade é justa"?; 2) Onde se encontra a verdade da declaração de Sócrates de que ao ter uma das virtudes se tem todas, já que onde existe uma parte da Justiça e a Justiça-ela-mesma não se encontra a Piedade? 


\subsubsection{O Segundo argumento do Protágoras e o Carmides}

Para a discussão entre Temperança, swfrosunh, e Sabedoria, sof ia, na continuidade do Protágoras, Sócrates inicia a investigação retomando um ponto que foi discutido na argumentação sobre a Justiça e a Piedade, que é a necessidade de se comprovar que existe uma identidade entre estas virtudes. Ele quer novamente demonstrar que existe uma enorme semelhança, que pode ser demonstrada, na relação entre a Temperança e a Sabedoria, pelo contrário que lhes é comum: a afrosýne. Sabemos que a Sabedoria, a Temperança e qualquer outra virtude só podem produzir algo que é da mesma natureza delas, ou seja, a Sabedoria só pode ter produtos sábios, assim como a Temperança só produz coisas temperantes, a ação temperante resulta da Temperança; a ação sábia resulta da Sabedoria. Da mesma maneira, uma ação contrária só pode produzir o seu contrário, de forma que: o contrário da Temperança é a afrosýne; o contrário da Sabedoria é a afrosýne. Isto está expresso na seguinte fala de Sócrates: "se um ato é concluído de uma certa maneira, ele é resultante da qualidade correspondente, e se ele é concluído de maneira contrária, ele é resultante da qualidade contrária” [332c]. ${ }^{3}$ Com base nisto, Sócrates conclui que cada contrário tem um único contrário correspondente ${ }^{4}$. Se é possível um mesmo termo, a afrosýne, ser o contrário de outros dois, a swf r osunh e a sof i a, então estas duas virtudes ou são muito próximas ou são a mesma coisa. A argumentação nos faz oscilar entre duas alternativas: ou para um único termo, um único contrário, então Temperança = Sabedoria; ou admitimos que elas são partes da virtude, portanto, distintas uma da outra.

\footnotetext{
${ }^{3} \mathrm{~K}$ ai. ei; ti dh. wsautwj prattetail uṕo. toulautoul prattetail kai. ei; ti enantiwjl uṕo, toul enantiou* $[332 \mathrm{c}]$.

4 É desta forma que o texto se apresenta no original grego: eni. ekastw/twh enantiwn eh monon estin enantion kai.ouvpolla* [332c].
} 
Sócrates suscita a questão: "a Temperança [swf r osunh ] e a Sabedoria [s of i a ] seriam uma única coisa [eh]?". Ora, nós vimos que "a Justiça e a Piedade são quase a mesma coisa", (to. de. proteron au=efanh himin h'dikaiosunh kai. ossiothj scedon ti taution on ), 333b. Podemos concluir disso que Sócrates admite que exista uma grande semelhança entre a Justiça e a Piedade, que elas são "quase" (s cedon ) a mesma coisa. Acreditamos que Sócrates utiliza o exemplo da Piedade e da Justiça para justificar que a mesma relação pode ser estabelecida entre a Temperança e a Sabedoria. A questão é como a Sabedoria e Temperança, que são idênticas a si-mesmas, admitem um único contrário, já que cada coisa admite somente um único contrário. Seria possível ou não conciliar estas duas coisas?

\subsubsection{O Terceiro argumento do Protágoras}

É o mais curto e o que não apresenta nenhum outro Diálogo conhecido que expõe esta relação entre a Justiça e a Piedade. Mas este argumento apresenta uma semelhança com os outros. Ainda, este argumento aparece no momento em que Sócrates tenta esclarecer que as virtudes dos argumentos anteriores revelaram uma espécie de identidade entre elas. Do segundo argumento, Sócrates se questiona se "a Temperança e a Sabedoria seriam uma única coisa" (333b). Provavelmente, elas devem ser, e a própria exposição do Protágoras nos induz a pensar assim, à maneira da relação estabelecida no primeiro argumento que afirma que "a Justiça e a Piedade são quase a mesma coisa" (333b). Para esclarecer que os argumentos devem ser idênticos, Sócrates surge com o terceiro argumento com o objetivo de exercer esta função. Este argumento alcançará tal fim se comprovar que entre a Justiça e a Temperança existe alguma identidade. Mas é uma tarefa que não chega ao seu termo. 


\subsubsection{Quarto argumento do Protágoras e o Laches}

Após a longa discussão sobre a poesia de Simônides, dá-se início ao quarto e último argumento, desta vez, uma relação entre a Coragem e a Sabedoria. Esta quarta relação surge no momento em que Protágoras considera que apenas quatro virtudes são muito parecidas, mas a Coragem é totalmente distinta de todas elas (349d). Se Protágoras admite que a Coragem é totalmente distinta das outras virtudes, deve assumir como conseqüência que: a) ela não seria uma virtude, pois não faria parte desta unidade de que todas as outras participam; ou b) ela seria um caso extraordinário, pois seria a única virtude, enquanto virtude, que não comporia esta unidade formada de virtudes.

Sócrates apresenta o seguinte argumento para comprovar que a Coragem e a Sabedoria estão bem próximas, e que podemos encontrar nelas um ponto de semelhança:

C1. Os corajosos são audaciosos;

C2. A Coragem é uma coisa bela;

C3. Os poceiros, os cavaleiros, os que combatem em peltastas etc., por terem o conhecimento, são mais audaciosos do que os ignorantes;

C4. Existem homens ignorantes e que são audaciosos em diversas circunstâncias;

C5. Valendo-se de C4, C1 e C2, Sócrates expões que estes itens entrariam em conflito, já que um ato audacioso sem conhecimento é loucura, portanto, é um ato feio.

C6. De C5 e C1, os corajosos são os audaciosos que possuem conhecimento;

C7. Logo, a Sabedoria é idêntica à Coragem. 
Protágoras apresenta a falha nesta argumentação de Sócrates. Sócrates identificou os corajosos com os audaciosos, mas não o contrário, os audaciosos com os corajosos. A audácia é mais ampla do que a Coragem, logo, não podem ser identificadas.

Além disso, Protágoras aponta outra falha na argumentação de Sócrates, que suscita uma nova questão, desta vez relativa ao "bem viver". Qual é a fórmula para bem viver? Seria viver conforme o que é agradável e fugindo da dor e do sofrimento? O que realmente seria agradável para o homem? Sócrates observa que existem homens que regulam seus atos com base em suas paixões, seus prazeres, dores, amores etc. Admitindo que os cometeram, estes homens justificam seus atos, sob o argumento de que foram comandados pelos prazeres, desejos etc. Mas qual seria o elemento na alma do homem que regularia seus atos de forma a preservá-los de todo o mal e encaminhálos na direção de prazeres superiores? Tanto para Sócrates, quanto para Protágoras, são a episthmh e a s of i a que devem comandar as ações do homem. Para ambos, os homens devem regular seus atos tendo em vista alcançar o bem supremo, que é o mais capaz, dentre todos os bens, de produzir os mais superiores prazeres. É necessário que os homens julguem que prazeres negar e que dores suportar, para alcançar este supremo bem. Os homens devem possuir a ciência que capacita a todos neste empreendimento, que lhes permite saber escolher quais são os prazeres reais e os que devem ser negados. Esta ciência deve lhes capacitar a estabelecer estas "proporções", ou seja, deve permitir aos homens saberem equilibrar seus desejos e impulsos em nome de um bem maior. Sócrates chama tal de ciência de "arte de medir", metrhtikh, Como toda teçnh envolve uma episthmh, podemos admitir que é uma "ciência da medida". Sócrates conclui disso que é a falta desta ciência que determina o erro de conduta daqueles que se dizem 
"vencidos pelo prazer", ou melhor, estes homens são ignorantes porque lhes falta esta ciência.

Mas ainda é preciso estabelecer a relação entre a coragem e a sabedoria. É necessário encontrar um elemento que, contido ao mesmo tempo numa e noutra, permita que a relação entre a coragem e as outras virtudes seja estabelecida. Para esta análise, Sócrates busca demonstrar que é necessário ter conhecimento para que o homem seja considerado corajoso. Sócrates acredita que todo erro de conduta é ausência de ciência, e que tais pessoas que comentem estes erros, os fazem pela razão de serem ignorantes. Por exemplo, ir a uma batalha é uma coisa boa e bela para Sócrates e Protágoras. Ora, são as coisas boas e belas que devem ser visadas na ação. Se o covarde recusa-se a participar das batalhas, ele estaria negando, voluntariamente, o que é belo e bom. Porém, se o homem recusa o que é belo e bom, buscando exatamente os seus contrários, o mau e o feio, ele comete este erro porque não tem o conhecimento do que é bom e belo, tampouco do que é feio e mau. Se o covarde pratica estes atos sem possuir o conhecimento requisitado, isto demonstra que ele é ignorante.

No movimento do Diálogo Protágoras, Sócrates se dá por satisfeito apenas com o exemplo do covarde e conclui que, se a Coragem demonstra ser o oposto da covardia, e a covardia é uma espécie de ignorância, a Coragem é, em consequiência, uma espécie de Sabedoria. E qual seria esta Sabedoria? "A Sabedoria relativa ao que é temível e ao que não é temível é Coragem, sendo o seu contrário a ignorância nestas matérias" (h'sofia ara twh deinwh kai. mh. deinwh andreia estin( emantia ousa thl toutwn amaqia $)$, 360d. Assim, novamente se demonstraria que existe uma relação possível entre mais duas virtudes, a Coragem, andreia, e a Sabedoria, sofia, precisamente aquelas entre as quais Protágoras não admitiu haver nenhuma relação. 
Pela própria definição dada para a Coragem, na qual a sabedoria está incluída nela, demonstrar-se-ia haver uma semelhança enorme entre estas duas virtudes.

Uma das questões suscitadas pelo Laches é a definição da Coragem, a ndr ei a . No desenrolar desta pesquisa, tal diálogo apresenta uma discussão e uma problematização que nos mobiliza a relacioná-lo com o Protágoras. Essencialmente, o Laches apresenta duas questões importantes: 1) a relação entre Coragem, a ndr ei a, e Sabedoria, s of i a, que é mesma relação estabelecida no Protágoras; e com base nesta primeira, 2) a questão da unidade das virtudes, representada na relação da coragem, enquanto mor i on, e a virtude toda inteira, sumpas a a veth,

Na definição de Nícias já aparece a determinação ética buscada por Sócrates. A questão propriamente ética entra na discussão, apontando as qualidades, "bom” e "mau", relativas às obras humanas. Como Nícias propriamente expressa, cada homem é bom relativamente àquilo que é sábio, e mau relativamente àquilo sobre o qual é ignorante [194 d]. Desta forma, sua definição concorda com aquela característica intelectual da Coragem apontada por Sócrates. A Coragem é um conhecimento que não está restrito a um determinado comportamento diante dos perigos externos ou dos internos (os perigos do mar, do clima etc. seriam os externos; as doenças, os desejos etc. seriam os internos). Se um homem tem este conhecimento, ele é sábio respectivamente nesta matéria que lhe confere este título, sendo assim, ele pode ser considerado como uma espécie de sábio; ou melhor, este homem é bom relativamente àquilo em que é sábio. Mas se o corajoso é uma espécie de sábio por ser corajoso, então a Coragem será uma espécie de Sabedoria. Esta é a conseqüência da afirmação de Nícias. Como nos diz Sócrates ao ver o resultado a que chega esta afirmação: “ele me parece afirmar que a Coragem é uma espécie de Sabedoria [s of i a ]" [194 d]. A afirmação de Nícias de que o homem corajoso é sábio só pode nos levar a concluir que a Coragem é uma espécie de 
Sabedoria. Não há a possibilidade de assumirmos que ela seja uma ignorância ou um vício. Mas, se ela é como tal, que tipo de sof i a é a andr ei a ? Que tipo de epistmh mh é a a ndr ei a ? [194 e]. A resposta que Nícias dá às perguntas de Sócrates quanto ao "gênero" de conhecimento que constitui a Coragem é: "a Coragem é o conhecimento [episthmh] daquilo que inspira o medo ou a confiança, quer seja na guerra ou em todas outras circunstâncias" [194 e].

Se Nícias assume que Coragem é idêntica ao "conhecimento daquilo que inspira o medo ou a confiança, quer seja na guerra ou em todas outras circuns tâncias", ele deve assumir também que a Coragem é idêntica a todas as outras virtudes. Esta conclusão surprendente de Sócrates é adquirida no seguinte argumento:

1. $\mathrm{O}$ "conhecimento daquilo que inspira o medo ou a confiança, quer seja na guerra ou em todas outras circunstâncias" deve ser o conhecimento dos bens e dos males futuros;

2. Toda episteme é do passado, presente e futuro, logo, o conhecimento dos bens e dos males futuros deve ser, também, dos bens e males passados e presentes;

3. Conhecimento dos bens e males passados, presentes e futuros é o conhecimento de todos os bens e males, ou seja, é o conhecimento dos bens e dos males como um todo;

4. O conhecimento dos bens e dos males como um todo é a virtude toda inteira;

5. Logo, a Coragem apresenta-se como a virtude toda inteira.

Com isto, entramos em um problema, como é possível que a Coragem, que é uma parte da virtude inteira, apresentar-se não mais como parte, mas como a própria sýmpasa arete? 


\section{Tese da Bicondicionalidade}

Esta tese tem como principal defensor Gregory Vlastos. Segundo este estudioso, a tese que Sócrates tenta defender é de que haveria uma inseparabilidade das virtudes. De forma que, estando uma presente, todas as outras também devem estar; Se uma faltar, todas as outras, necessariamente, também deve faltar no agente. A questão da unidade das virtudes surge em Prt. 329C-D, em que encontramos a primeira tese posta dentro da argumentação que Vlastos nomeia de Tese da Unidade. A partir deste ponto se desenvolvem mais duas outras tese que serão chamadas por este estudioso de Tese da Similaridade e Tese da Bicondicionalidade. Reconstruiremos a argumentação de Vlastos seguindo os seus passos. Exporemos o que é cada uma dessas teses, até chegarmos à própria conclusão de Vlastos de que todas são momentos próprios do esclarecimento da argumentação. Estes momentos servem para tornar clara a única doutrina que é exatamente aquela que Sócrates quer defender.

\subsection{Tese da Unidade}

Como afirmamos anteriormente, o que Vlastos chama de Tese da Unidade é a seguinte passagem: "qual dessas duas hipóteses: [A] a virtude é uma unidade, na qual a Justiça, a Temperança, a Piedade são partes [noria] dela, ou [B] estas coisas que mencionei, todas são nomes [pant a onomata] de um único e mesmo ser [t ou/a ut ou/ eñoj ont oj]?" (329 c). O esforço, nesta presente indagação, é o de determinar que tipo de unidade a Virtude é. Daí, as duas opções que foram postas diante de Protágoras em relação à unidade da Virtude, são:

[A] ou a Virtude é um eh e Justiça, Temperança etc. são partes deste eh; 
$\mathrm{Ou}$

[B] Virtude, Justiça, Temperança etc. são todas nomes de uma mesma coisa, ou seja, quais destas duas opções revelam a verdade desta unidade buscada.

\subsection{Tese da Similaridade}

Das duas alternativas postas por Sócrates:

[A] ou a Virtude é um eh e Justiça, Temperança etc. são partes deste eh;

ou

[B] Virtude, Justiça, Temperança etc. são todas nomes de uma mesma coisa, Protágoras escolhe a alternativa [A]. A segunda proposição [B], para os defensores da Tese da Identidade, que discutiremos no próximo tópico, é tomada como a posição propriamente socrática, já que isso nos leva a considerar que todas as virtudes são idênticas. Vlastos concorda que a segunda proposição expressa a tese da identidade, mas essa não pode ser considerada a posição socrática, já que chocaria com o que ele nomeia de "doutrina socrática padrão" (standard Socratic doctrine). Esta doutrina é a que considera as diferentes virtudes como partes distintas de um todo. Vlastos, por pensar que [A] é a doutrina socrática padrão, considera que [B] apenas cumpre a função de alternativa para [A] e, além disso, o desenrolar da argumentação em 329d, estaria sendo considerado como uma conseqüência de [A]. As proposições apresentadas por Sócrates são:

[C] As virtudes são partes como as partes do rosto;

\footnotetext{
5 Esta doutrina socrática padrão, nomeada por Vlastos, baseia-se no fato de que no Laches e no Mênon (78d-79e), Sócrates sustenta que a virtude é um todo formado de partes. Contra Vlastos, encontramos a tese de Devereux que sustenta que a teoria da unidade das virtudes apresentada no Protágoras é completamente diferente da que é apresentada no Laches. Cf. Daniel T. Devereux, The Unity of the Virtues in Plato's Protagoras and Laches, 1992.
} 
[D] como as partes de uma barra de ouro.

Prosseguindo o exame, se as virtudes são partes distintas de um todo, o objetivo agora é determinar como cada virtude se comporta uma em relação a outra e como cada uma se comporta com o todo, segundo o próprio encaminhamento da argumentação presente no Diálogo. Visando isto, Vlastos pretende em seu texto discutir a chamada tese da Similaridade. Ele utiliza uma lista de frases que contêm palavras que expressam esta similaridade. Utilizaremos aqui a mesma lista apresentada no texto de Vlastos. No caso, ele utiliza A e B como substitutos das virtudes:

[1] $B$ e $A$ "não diferem em tudo puden diaf er ei ] ... exceto em tamanho". $(329 \mathrm{~d} 1-2)$

[2] $B$ é "tal qual" $A$ (est in to. ef er on oi on to. ef er on ). (330a8-b1)

[3] A "capacidade" (duna mi j) de $B$ é tal como aquela de $A$. (330B1)

[4] $B$ é semelhante (o moi on) a $A$. (349c3)

[5] B é "ou a mesma coisa que $A$ ou tão similar a $A$ quanto possivelmente poderia ser" ktoi tauton gVestin dikaiothj osiothti h; oti omoiotaton). $(331 b 4-5)$

[6] B é "quase a mesma coisa que A" (scedon ti tauton). (333b5-6)

Ao que parece, temos uma tese completamente oposta à primeira, nomeada Tese da Unidade, por assumir, como as expressões acima nos mostram, que as virtudes são tão similares quanto a relação entre os pedaços de uma barra de ouro, ou melhor, o sentido que Sócrates pode dar a esta similaridade é de uma analogia das virtudes com os pedaços de uma barra de ouro. 


\subsection{Tese da Bicondicionalidade}

Esta terceira tese surge logo em seguida às teses da Unidade e da Similaridade. Sócrates questiona: “Alguns homens participam destas partes da virtude, alguns outros de outras, ou é necessário que tendo possuído a unidade se possua todas?" (poter on ouf, ha dV evgw, kai. metal ambanousin oi angrwpoi toutwn twh thi arethi moriwn oi' men allo, oi'de.allo,h. anankh, eanper tij eh Iaphl apanta ecein;, 329e). De acordo com esta tese, é suficiente ter apenas uma das virtudes para se ter todas as outras. Se um indivíduo possui a Coragem, ele também possui a Sabedoria, a Justiça, a Temperança e a Piedade. Porém, se ele não possui uma delas, ele não possui nenhum.

Porém, o que vale ressaltar é que tanto Vlastos como outros comentadores identificam a última opinião a Sócrates - tendo-se uma tem-se todas. Valendo-se disto, ele conclui que as cinco virtudes constituem disposições co-extensivas. Vlastos expressa esta tese na seguinte fórmula: necessariamente, para todo indivíduo, se ele é corajoso, então ele é justo; se ele é justo, então ele é pio; se ele é pio, então ele é temperante; se ele é temperante, então ele é sábio. Isto é válido para qualquer uma das virtudes, salvo a Sabedoria, que ocuparia um lugar privilegiado diante das outras virtudes, sendo esta a real reivindicação de Sócrates, já que todas as outras são espécies de Sabedoria. O que Vlastos conclui é que a Sabedoria é uma condição necessária para a existência de todas as outras. Como ele mesmo expressa: "a sabedoria é uma condição necessária para possuir quaisquer uma das outras virtudes". ${ }^{6}$ Ele também diz que o esforço de Sócrates é o de provar que o conhecimento é não apenas uma condição necessária, mas também uma condição suficiente. Para demonstrar esta interpretação, Vlastos aponta a seguinte passagem: "por acaso a ciência te parece bela e capaz de comandar o homem? Se

\footnotetext{
${ }^{6}$ Vlastos (1971): "Wisdom is a necessary condition for possessing any of the others virtues", p.
} 233. 
alguém conhece o que é bom e o que é mal, por acaso nada lhe pode dominar e lhe induzir a fazer coisas diferentes daquelas que a ciência lhe prescreve? A inteligência pode constituir um socorro suficiente para o homem?" (h. kal on te ei fai h'episthmh kai. oion arcein tou/amgrwpou, kai, eanper gignwskhltij tagaqa,kai,ta,kaka, mh. an krathqhhai upo. mhdenoj wste all Vatta prattein $h$. ah episthmh kel euh, all Vikanhn ei ai thn fronhsin bohqein tw/ angrwpw: 352c). Prosseguindo no diálogo com Sócrates, Protágoras diz: “o saber e a ciência são as espécies de coisas que existem de mais potente em todas as ações humanas ", e Sócrates conclui: "tu falas bem, e o que tu dizes é verdade" (p. 352d). Ou seja, para que alguém possua todas as virtudes, uma condição deve ser considerada: é necessário possuir antes a Sabedoria. São as seguintes as palavras de Vlastos: “a sabedoria é uma condição necessária para possuir qualquer uma das outras virtudes; e é também suficiente, no mesmo sentido forte, pois Sócrates está convencido que pode provar sobre razões lógicas que um homem que é sábio terá que ser temperante, corajoso etc". ${ }^{7}$ Mesmo que seja demonstrado que a Sabedoria ocupa este lugar privilegiado diante das outras virtudes, esta afirmação não iria de encontro à declaração de que se possuindo uma se tem todas, pois, na investigação, se é provado que um indivíduo possui somente uma delas, é sinal de que este possui todas as outras.

\subsubsection{As duas teses como momentos da Tese da Bicondicionalidade}

Dada estas três teses, Vlastos se empenha em demonstrar que todas elas cumprem o papel de tender para uma única doutrina, a saber, a de que todas as virtudes estão bicondicionalmente relacionadas. Ele se serve de uma proposição, considerando

${ }^{7}$ Vlastos (1971): "so Wisdom is a necessary condition for possessing any of the others virtues; and it is also sufficient, and in the same strong sense, for Socrates is convinced that he can prove on logical grounds that a man who is wise will have to be temperate, and brave, etc" p. 233. 
que esta é elo de ligação entre as três teses. A proposição que Vlastos tem em mente é a seguinte:

L: Virtude, Sabedoria, Temperança, Coragem, Justiça e Piedade são interpredicáveis.

Cada uma destas palavras podem ter adjetivos cognatos para cada outra. O que se segue é que podemos determinar sentenças como:

A Justiça é sábia;

A Justiça é temperante etc.

Se a tese da Bicondicionalidade for verdadeira, $L$ também será verdadeira. Do mesmo modo se $L$ for verdadeira a tese da Bicondicionalidade também será verdadeira. Toda a questão neste momento é, pois, demonstrar que as teses da Unidade e da Similaridade estão incluídas na tese da Bicondicionalidade.

\subsubsection{Tese da Unidade Subsumida à Tese da Bicondicionalidade}

Para a tese da Unidade, Vlastos considera duas coisas: 1) os sentidos de "nome" (o no ma ); 2) as virtudes são co-extensivas. Sobre o nome, Vlastos diz o seguinte: “durante todo o período arcaico e clássico o 'nome' ( o n ma ) era prescrito a cumprir duas funções lingüísticas radicalmente diferentes: a primeira destas, é claro, o de nome próprio, este é o original, e sempre primário, uso de onoma; segundo, aquele de nome comum, serve para dizer do predicado qualificador ou expressão descritiva". ${ }^{8}$ O que ele quer dizer é o seguinte: dada uma expressão do tipo "a Justiça é sábia”, tanto Justiça

8 Vlastos (1971): "all through the archaic and classical periods the 'name' (onoma) was expected to perform two radically different linguistic functions: first, of course, that of the proper name: this is the original, and always the primary, use of onoma; but secondly that of the common name, that is to say of the qualifying predicate or descriptive expression"p. 238. 
quanto sábia são nomes. O que interessa, no entanto, é qual significado que este nome está ocupando, ou seja, se este onoma tem a função de nome próprio ou se ele tem a função de uma expressão predicativa ou descritiva. Por exemplo, tomemos os nomes "ímpar" e "três". Se dissermos que três é impar, o nome três ocupa o lugar de referência (esta palavra nomeia o número Três) e ímpar ocupa o lugar de expressão descritiva (ele diz algo de Três, ou melhor, ele expressa uma qualidade de Três). Logo, Três tanto tem o nome de três como o nome de ímpar, o que não implica que três e ímpar sejam sinônimos. Com a expressão "a Justiça é sábia” se dá o mesmo: a Justiça tanto tem o nome de Justiça como tem o nome de sábia e nem por isso Justiça e Sabedoria são a mesma coisa. O que Vlastos conclui é que Sócrates ao dizer que são cinco nomes para uma única coisa, ele queria dizer que uma virtude, no caso Justiça, pode vir a ter atribuídos a ela cinco nomes diferentes, a Justiça é justa, sábia, temperante, corajosa e piedosa. Aqui, foi provada a verdade da proposição $L$, pois se tornou evidente que todas as virtudes são interpredicáveis. Se $L$ é verdadeira, a tese da Bicondicionalidade, por este viés, também o é.

Atentando para as conclusões anteriores, pode ser concluído que as virtudes são co-extensivas. Se pensarmos na gramática “A é B”, em que A é o substantivo e B o adjetivo cognato; A é a extensão da classe dos objetos representados por B. Com isso, temos que:

Justiça é sábia;

Justiça é temperante;

Justiça é corajosa;

Justiça é pia;

Justiça é justa;

Justiça é virtuosa. 
Este termos predicados permanecem verdadeiros quando são postos em sua forma substantivada:

Justiça é Sabedoria;

Justiça é Temperança;

Justiça é Coragem;

Justiça é Piedade;

Justiça é Justiça;

Justiça é Virtude.

Com base nestas sentenças, mutatis mutandis, a Justiça passa a ser a extensão das classes das outras virtudes, assim como toda e qualquer outra das quatro virtudes cardinais. Isto é permitido porque o intercâmbio de termos co-referências em contextos extensionais faz com que as sentenças permaneçam com seus valores de verdade. Se um sujeito qualquer apresentar uma dessas virtudes, ele deve necessariamente apresentar todas as outras - isto é o que a tese da Bicondicionalidade nos proporciona. Se isto é verdade para este sujeito deve ser verdade para todos os outros. Logo, a extensão do termo "Justiça" é a classe dos justos, assim como dos sábios, dos corajosos, dos temperantes e dos piedosos, assim como qualquer outra extensão do termo-virtude serão as classes dos justos, temperantes, corajosos, sábios e piedosos. Mais uma vez, segundo Vlastos, a tese da Unidade foi provada ser um dos momentos da tese da Bicondicionalidade.

\subsubsection{Tese da Similaridade Subsumida à Tese da Bicondicionalidade}

Se cada uma das virtudes tem a qualidade de todo o resto, então ter uma das virtudes é ter todo o resto também. Logo, se alguém tem a Justiça, isto implica que este 
indivíduo necessariamente tem a Sabedoria, a Coragem, a Piedade e a Temperança, ou seja, se alguém possui a virtude da Justiça e sendo ela sábia, temperante, corajosa e pia, este homem justo, exatamente por ter esta qualidade, é também sábio, temperante, corajoso e piedoso. Segundo Vlastos, esse critério pode ser aplicado para a coextensividade das virtudes e para a tese da similaridade, daí por que a tese da Bicondicionalidade as inclui.

\section{Tese da Identidade}

A Tese da Identidade afirma, em linhas gerais, que todas as virtudes são idênticas. Esta tese assume posição forte:

TI. Sabedoria $[$ sofía $;$ epist $? m e ;$ frónesis $]=$ Justiça $=$ Piedade $=$ Temperança $=$ Coragem.

Entre seus defensores temos Penner, Ferejohn e Zingano. As interpretações destes estudio sos da $T I$ serão expostas a seguir.

\subsection{Penner}

O objetivo de Penner é demonstrar que Sócrates teve por meta defender a tese da Identidade como a verdade da doutrina da unidade das virtudes:

$$
\text { Sabedoria }=\text { Justiça }=\text { Piedade }=\text { Temperança }=\text { Coragem } \text {. }
$$

Contra esta interpretação, alguns estudiosos, entre eles Vlastos (a qual Penner deve estar se referindo quando fala dos defensores do que ele chama de ponto de vista do significado), declaram que, se isso for verdade, a essência de cada virtude é igual à essência da outra, ou melhor, só existiria uma única essência: 
A essência da Sabedoria $=$ a essência da Coragem,

Para que tal sentença seja verdadeira, de acordo com estes estudiosos, é necessário que estes termos sejam sinônimos, o que resulta:

O significado de Sabedoria $=$ significado de Coragem .

O que não pode ser verdadeiro, já que, como Penner se expressa "nada poderia ser mais óbvio", o significado de Sabedoria é diferente do significado de Coragem. Penner os nomeou de defensores do "ponto de vista do significado" (the meaning view), que defendem que a solicitação de Sócrates para a sua questão é um pedido por significados ou essências ou universais.

A base para que ele assuma esta identidade está na expressão: "Virtude é conhecimento", onde:

Virtude $=$ conhecimento

Esta relação de identidade entre a Virtude e o conhecimento passa a ser o termo que nos permitirá assumir que a Coragem (que é aquilo que está além dos homens corajosos) é idêntica à Temperança (que é aquilo que está além dos homens temperantes). Para tornar esta interpretação evidente, Penner fará uma nova leitura da questão “o que é X?”. Para ele, o pedido de Sócrates não é uma solicitação por significados, essências ou universais: "Quando Sócrates perguntou "o que é a coragem?" e assim por diante, ele não quis saber qual era o significado da palavra “coragem", nem qual era a essência da coragem, nem qual era o universal coragem". 9 Assumindo esta posição, Penner fugiria da objeção dos defensores do ponto de vista do significado. Se não é um pedido por significados, essências ou universais, é necessário saber o que é isto que Sócrates pretende alcançar.

9 Penner (1973): “when Socrates asked 'What is bravery?' and so forth, he did not want to know what the meaning of the word 'bravery' was, nor what the essence of bravery was, nor what the universal bravery was", p.39. 
Ele alcançará isto acompanhando a argumentação que objeta sua interpretação. Na questão socrática “o que é X?”, X são as referências:

\author{
"Sabedoria" \\ "Coragem" \\ "Justiça" \\ "Temperança" \\ "Piedade"
}

Cada uma destas referências não são outra coisa senão disposições: "se nós somente pensássemos em uma forma de sentido comum sobre a referência de "coragem", "sabedoria" e assim diante, nós veríamos que as referências são disposições". ${ }^{10}$ Logo:

"Sabedoria" = disposição ao comportamento sábio;

"Coragem" = disposição ao comportamento corajoso;

"Justiça" = disposição ao comportamento justo;

"Temperança" = disposição ao comportamento temperante;

"Piedade" = disposição ao comportamento pio.

Com isto:

A disposição ao comportamento corajoso é diferente da disposição ao comportamento sábio.

Se "Sabedoria", "Coragem" e assim por diante, são disposições para tipos diferentes de comportamento, as disposições devem, também, ser diferentes:

"Sabedoria" é difererente de "Coragem".

Assim, a objeção toca dois pontos:

\footnotetext{
${ }^{10}$ Penner (1973): "if we just think in a common-sense way about the reference of 'bravery',
} 'wisdom', and so forth, we will see that the references must be dispositions”, p. 44. 
a) As disposições (“Sabedoria”, "Coragem” e assim por diante) são diferentes se e somente se elas possibilitam tipos diferentes de comportamento;

b) Comportamento corajoso é diferente do comportamento sábio.

Quanto ao item (b) não existe necessidade de se questionar se é verdadeiro ou não. Que o comportamento corajoso é diferente do comportamento sábio, não há dúvida. O problema repousa, exatamente, sobre o item (a). Para a objeção, as referências devem ser consideradas como "tendências". De forma que:

a') As tendências ("Sabedoria", "Coragem” e assim por diante) são diferentes se e somente se elas possibilitam tipos diferentes de comportamento;

A questão que tenta se opor à interpretação de Penner, segundo ele, é se o uso das palavras "Coragem", "Sabedoria", assim por diante, deve significar tendências ou devem significar a leitura deste estudioso:

a) Coragem e Sabedoria são "forças-motivacionais" ou "estados da alma";

B) uma única e mesma "força-motivacional" ou "estado da alma" resulta em diferentes tipos de comportamento.

Tendo isto em mente, para Penner, quando Sócrates perguntava "o que é a Coragem?", ele estava, na verdade, perguntando: "o que é isto que torna os homens corajosos?". Contrastando com o "ponto de vista do significado", Penner defende o “ponto de vista causal” da questão “o que é X?": “O que eu mantenho é isto. Quando Sócrates perguntou 'o que é a coragem?' e assim por diante, ele não quis saber o que o significado da palavra 'coragem' era, nem qual era a essência da coragem, nem qual era o universal coragem ... Sua questão era um tanto a questão geral, 'o que é coragem?' isto é, 'o que é isso que torna os homens corajosos corajosos?'. O general pergunta estas questões não fora de interesse em mapear nossos conceitos, mas fora de um desejo em aprender alguma coisa substancial sobre a psique humana. Ele deseja saber que estado 
psicológico isso é, a comunicação do que para seus homens os tornariam corajosos". ${ }^{11}$ A coisa única que Sócrates pretende encontrar é o estado psicológico cuja presença no agente o possibilita agir conforme este estado. Desta forma, este estado psicológico é o que Penner chama de "força-motivacional" ou "estado da alma". Então, o estado psicológico (que seria a "força-motivacional" ou "estado da alma") que torna um indivíduo corajoso é igual ao estado psicológico que torna um indivíduo sábio e assim por diante.

\subsection{Ferejohn}

O objetivo de Ferejohn é demonstrar que não existe inconsistência em defender tanto a tese da identidade quanto o ponto de vista do significado. Ele fundamente este seu esforço argumentando que Sócrates não está compromissado com a procura pela sinonímia dos termos-virtude. A tese da identidade não implica sinonímia. Assim, Ferejohn precisa demonstrar que “(i) os vários termos-virtude não são sinônimos, (ii) que estes termos, contudo, referem-se (são 'nomes' de) a um único universal, e (iii) que a correta resposta para uma aplicação da questão 'O que é $X$ ?' a qualquer uma das virtudes especiais necessariamente envolverá alguma especificação (embora nem sempre a mesma especificação) deste único universal 'nomeado' por todos os termos-

\footnotetext{
${ }^{11}$ Penner (1973): “o que eu mantenho é isto. When Socrates asked 'what is bravery?' and so forth, he did not want to know what the meaning of the word 'bravery' was, nor what the essence of bravery was, nor what the universal bravery was ... His question was not (what has become) the philosopher's question...His question was rather the general's question, 'what is bravery?' - that is, 'what is it that makes brave men brave?' The general asks this question not out of interest in mapping our concepts, but out of a desire to learn something substancial about the human psyche. He wants to know what psychological state it is, the imparting of which to his men will make them brave", p. 39-40.
} 
virtude". ${ }^{12}$ Portanto, o esforço deste estudioso é encontrar este único universal que todos os termos-virtude referem-se. Este universal é o que cada virtude é, cada uma é um tipo especial de conhecimento. Tal tipo de conhecimento, que é cada uma das virtude, é descrito como o conhecimento do bem e do mal, opinião compartilhada pela maior parte dos comentadores. Valendo-se de um desacordo entre Penner e Vlastos quanto à utilização do termo dýnamis e da passagem da República V [477b-478d], assim como o fato de Sócrates considerar todas as virtudes cardinais como uma única dýnamis, sendo que esta única dýnamis é idêntica ao "conhecimento do bem e do mal”, no entanto, conhecimento, segundo República V, é a capacidade de discernir. Ferejohn conclui que este conhecimento-dýnamis é "tanto a única coisa da qual todos os termos-virtude são 'nomes' quanto o universal que Sócrates deseja especificar quando pergunta "O que é a piedade?", e assim por diante". ${ }^{13}$

Ferejohn, para escapar do caso em que a identidade implica a sinonímia dos termos-virtude, demonstra o que seria este conhecimento-dýnamis, apelando para a natureza própria de toda dýnamis, a saber, existe alguém que tem o poder (dýnamis) de fazer determinado ato e deseja fazê-lo e existindo a melhor ocasião para realizá-lo, este indivíduo deve realizá-lo. Mas para que este agente realize uma ação, ele necessita não apenas do poder de discernir bens e males mas também de propriedade acidentais que permitam a realização deste ato. Logo, para a realização de um ato de Coragem o agente necessita ter esta capacidade de discernir e as propriedades acidentais relativas à

\footnotetext{
${ }^{12}$ Ferejohn (1995): “(ii) the various virtue-terms are not synonymous, (ii) that these terms nevertheless refer to (are 'names' of) one single universal, and (iii) that the correct answer to an application of the What is $\mathrm{X}$ ? question to any of the special virtues will necessarily involve some specification (though not always the same specification) of this single universal 'named' by all of the virtue-terms", p. 419.

${ }^{13}$ Ferejohn (1995): "both the single thing of which all the virtue-terms are 'names' and the universal that Socrates wants specified when he asks 'What is piety?' and so on”, p. 421.
} 
Coragem, o que pode ser as técnicas de manejar o escudo, montaria, uma boa estrutura física etc.

\subsection{Zingano}

A interpretação de Zingano tenta responder duas objeções contra a tese da identidade. A primeira delas se baseia nas seguintes afirmações:

1) A justiça é aquilo graças a que todas as coisas justas são justas;

2) A piedade é aquilo graças a que todas as coisas pias são pias.

Se todas as virtudes são idênticas, pode se dizer, com verdade, que cada virtude pode ser substituída uma pelas outras sem alterar o valor de verdade das proposições. Assim, seria verdade afirmar que:

3) A justiça é aquilo graças a que todas as coisas pias são pias;

4) A Piedade é aquilo graças a que todas as coisas justas são justas;

Para que 3 e 4 sejam verdadeiros é necessário assumir que seus termos possuam as mesmas definições, e que isto demonstra a sua identidade. Porém, isso é falso, como Zingano afirma: "a substituição salva veritate demonstra somente que os termos têm o mesmo referente, não que eles têm o mesmo sentido". ${ }^{14}$ Para que esta primeira objeção seja verdadeira, seria necessário considerar que toda identidade implica uma única e mesma definição. É verdade que tudo que for idêntico é inteiramente idêntico, enquanto idêntico. Não podemos falar de uma identidade parcial. É desta forma que Protágoras se expressa: “é certo que existe alguma semelhança entre a Justiça e a Piedade, replicou ele, há sempre semelhanças entre as coisas, de uma maneira ou de outra. O branco, para alguns, parece-se ao negro, o duro ao mole, assim

\footnotetext{
${ }^{14}$ Zingano (2004), p. 3.
} 
com todas as coisas as mais contrárias na aparência. Estas partes do rosto, nas quais distinguíamos antes as propriedades, e que dizíamos ser diferentes, não estão, portanto, sem alguma semelhança entre elas e sem algumas relações. Segundo teu proceder, poderias demonstrar, se o desejasses, que são todas parecidas entre elas. Não é permitido, porém, chamar de semelhantes as coisas que têm algum ponto de semelhança, nem ainda diferentes as que diferem em algum ponto, por fraca que seja a sua parecença" (Prt. 331d-e). Por esta perspectiva, todas as coisas, por mais dissemelhantes que sejam, e que ainda possuam alguma identidade que seja mínima, esta fraca identidade é absoluta. Da mesma forma, as coisas dissemelhantes, por mais idênticas que sejam sob certo aspecto, são radicalmente dissemelhantes por menor que seja a diferença. Seguindo esta mesma esteira da primeira objeção - se as virtudes são todas idênticas e, com isso, temos uma única e mesma virtude - alguns estudiosos se perguntaram: como se poderia falar em partes da virtude toda inteira? Se a virtude toda inteira é uma única virtude - com isto, esta identidade não seria de qualquer tipo, mas forte e bem fundada - como é possível falar em partes da virtude? Esta identidade bem fundada, segundo Zingano, deve ser considerada sob um certo aspecto. Ela deve realizar-se sob o aspecto essencial, ou seja, a identidade das virtudes é exatamente a essência comum a todas elas. Como Zingano se expressa: "Sócrates não sustenta uma identidade selvagem ou vaga, mas uma tese precisa e bem controlada da identidade das virtudes". ${ }^{15}$ A identidade, para Zingano, se dá sob o aspecto essencial das virtudes e somente sob este aspecto, o que permite a diferença entre elas não desaparecer. São estes os dois pontos fortes da interpretação de Zingano do paradoxo da unidade das virtudes.

\footnotetext{
${ }^{15}$ Idem, p. 4.
} 
A interpretação que Zingano propõe é que esta essência - como ele se expressa ao citar o trecho do Laches (189e4: paragenomenon tw beltion poiei/ ekeiho w parageneto) - é aquilo cuja presença torna melhor a coisa em que se está presente. Servindo-se das passagens do Laches [a passagem (199d-e): "tens a impressão, divino Nícias, que um semelhante homem negligenciaria alguma coisa da virtude, se verdadeiramente ele conhecesse todos os bens e todas as maneiras das quais eles se produzem, se produzirão e são produzidos, e paralelamente para os males? E tu crês que ele falhará ou de moderação, ou de justiça e piedade, ele que será o único com capacidade de se prevenir, tanto ao olhar dos deuses quanto dos homens, do que é temível e do que não o é, e de procurar bens graças a seu conhecimento da boa maneira de ter comércio com eles?"; e a passagem (199e): "isto que tu falas presentemente, Nícias, não seria, portanto, uma parte da virtude, mas a virtude toda inteira"] e do Protágoras (361b: todas as coisas são ciência), ele afirma que esta essência é o saber. Logo, este saber é o que permite que os homens e os atos sejam considerados como justos, temperantes e corajosos. Não mencionar a Sabedoria foi proposital, já que este saber, esta essência, é uma das virtudes, pois "se destaca da justiça, da coragem e da temperança na medida em que é o princípio ou a causa de ser virtuoso". ${ }^{16}$ A Sabedoria, portanto, é a causa da presença das outras virtudes. É necessário ter a Sabedoria para se ter todas as outras. Assim, todas as virtudes são tipos de Sabedoria; sua diferença é dada pelos diferentes domínios em que esta Sabedoria é aplicada.

\footnotetext{
16 idem, p. 16.
} 


\section{Mediações Necessárias Concernentes ao Paradoxo da}

\section{Unidade das Virtudes}

\section{Definição socrática}

As investigações socráticas sempre envolvem uma série de perguntas e respostas. Sócrates elabora suas questões e seus interlocutores se comprometem em respondê-las. Robinson diferencia essa série de questões entre primárias e secundárias. As primárias estão direcionadas, usualmente, a um problema ético. As secundárias seriam as questões que se desenvolvem tendo por base as questões primárias.

Nossa tarefa, nesse momento, se concentrará nestas questões primárias. Tais questões são as que mais detém a atenção dos estudiosos desses diálogos, e aqui não faremos diferente. Primeiramente, existem duas formas de questões primárias, a saber: a forma “X é Y?"; e a forma “O que é X?". Podemos encontrar exemplos desta primeira forma na República, onde é questionado “a Justiça é melhor do que a Injustiça?”, no Lysis, “aqueles que são amigos, são semelhantes uns aos outros?”; e no Criton, “Sócrates deve escapar?". Os exemplos da segunda forma encontramos no Laques, “o que é a Coragem?"; no Carmides, "o que é a Temperança?"; no Eutífron, "o que é a Piedade?". A maior parte dos pesquisadores concentra-se nesta segunda forma, cada um por seus motivos respectivos. No nosso caso, iremos nos concentrar nesta segunda forma por estar diretamente relacionada a um problema que diz respeito, como veremos, à seguinte pergunta: que objetivo Sócrates, ao fazer suas perguntas nos parâmetros da forma “o que é X?", tem em mente? O que ele gostaria de alcançar com tal pergunta? Seria a definição, a essência, o universal da coisa em questão ou ele teria em mente uma outra coisa completamente distinta destas anteriores? 
Antes de tudo, é algo que salta aos olhos a insatisfação, por parte de Sócrates, das respostas dadas por seus interlocutores para as suas questões primárias. Robinson tem a seguinte explicação para essa atitude socrática: "Sócrates, freqüentemente, expressa insatisfação com a resposta que ele recebe para a sua questão O-que-é-X?, não é pela razão de que é falsa mas que ela não é o tipo de resposta que ele tinha em mente quando perguntou 'O que é X?'” ${ }^{17}$ Realmente, e nós cremos nisto, o objetivo de Sócrates não é o de provar a falsidade das respostas de seus interlocutores, e acreditamos que o tipo de resposta que Sócrates tem em mente deve ser aquela que obedece a dois critérios fundamentais, os quais trataremos logo em seguida.

Robinson dá como exemplo para ilustrar essa insatisfação de Sócrates a seguinte passagem do Teeteto (146). Como resposta à questão primária "O que é o conhecimento?", Teeteto expõe vários tipos de conhecimento. Sócrates fala que seu objetivo não seria uma exposição de tipos de conhecimento, mas saber o que é o conhecimento. Freqüentemente, Sócrates oferece uma ilustração de como a resposta deve ser dada. No Teeteto, ele exemplifica valendo-se da pergunta, “o que é a lama?”, se esta pergunta é feita por Sócrates, seu objetivo é saber o que é a lama e não tipos desta coisa, mas simplesmente "terra misturada com água" (147C). No Mênon, encontramos a mesma ilustração quando ele, para questão, “o que é a figura?”, designa como uma boa resposta a seguinte: "o limite do sólido" (76a). Outro exemplo, desta vez na esfera dos propriamente socráticos, é o encontrado no Laques. Neste, o exemplo será o da velocidade (192a-b). No Eutífron e Carmides a mesma insatisfação é encontrada, porém em tais Diálogos não existem referências de que Sócrates utiliza, como nos Diálogos já citados, o exemplo do tipo de resposta esperada, ou melhor, ele não

\footnotetext{
${ }^{17}$ Robinson (1953): "Socrates often expresses dissatisfaction with the answer he receives to his What-is-X? question, on the ground that it is false but that it is not the Kind of answer he had in mind when he asked 'What is X?'”, p. 50.
} 
demonstra passa a passo como nos servindo de uma pergunta poderíamos, logo em seguida, lhe dar uma resposta adequada. Em todos estes exemplos existem dois argumentos principais dos quais Sócrates faz uso para expressar seu desejo, ou melhor, existem dois critérios que devem ser considerados para se responder às questões socráticas. Estes critérios estão intimamente relacionados com a questão O-que-é-X?, e Robinson nos confirma isso quando diz que um dos critérios é 'a oposição entre o 'um' e os 'vários' - ele deseja o único conhecimento e não os vários conhecimentos. O outro é 'o que X ele-mesmo é'. Estas frases constantemente ocorrem quando Sócrates está tratando de sua questão O-que-é-X?". ${ }^{18}$ Porém, com base nos critérios acima apontados, a saber, o "um-de-muitos" e o "X-ele-mesmo", a investigação visa o mesmo fim. Não se trata de um critério oposto ou diferente ao outro, e podemos dizer mais, o primeiro tem por objetivo o segundo.

Fine apresenta uma interpretação similar à de Robinson, já que ela considera que a resposta ideal é aquela que procura a f-dade de F, ou poderíamos dizer, a essência de F ou F-ele-mesmo: "além de ser nem tão estreita nem tão ampla, uma correta resposta para a questão "O que é F?" deve também explicar a natureza da fdade. No Eutífron (10-11), por exemplo, Sócrates diz que embora 'piedade' e 'ser amado por todos os deuses' sejam coextensivas, 'ser amado por todos os deuses' é, apesar disso, uma resposta inadequada para a questão 'O que é piedade?', já que ser amado por todos os deuses é uma propriedade acidental (pathos, Eu. 11a8) da piedade, uma vez que Sócrates deseja saber sua natureza ou essência". ${ }^{19}$

\footnotetext{
${ }^{18}$ Robinson (1953): "the opposition between the 'one' and the 'many'; he wants the one knowledge and not the many knowledges. The other is 'what $\mathrm{X}$ itself is'. These phrases constantly recur when Socrates is talking about his What-is-X? question", p. 50.

${ }^{19}$ Fine (1993): "In addition to being neither too narrow nor too broad, a correct answer to a "What is F?" question must also explain the nature of f-ness. In the Euthyphron (10-11), for exemple, Socrates says that although 'piety' and 'being loved by all the gods' are coextensive, 'being loved by all the gods'
} 


\subsection{Os critérios}

\subsubsection{O critério "um-de-muitos"20}

Algo que salta aos olhos nos Diálogos socráticos é a necessidade de se buscar aquela coisa única que está presente em vários tipos particulares desta coisa, ou seja, é necessário investigar o que é esse $\mathrm{X}$ que faz com que várias coisas sejam consideradas como tipos desse X. Um excelente procedimento, para se alcançar o objeto desejado pelo pedido de Sócrates, é encontrar este "um de muitos". Em todos os Diálogos que pretendemos investigar - que são o Protágoras, Eutífron, Carmides e Laches, o mesmo será observado no Mênon - esse procedimento é encontrado.

O Protágoras não nos oferece um exemplo que podemos considerar como o mais indicado para o que pretendemos alegar. Mas sua discussão pode ser iluminada

is none the less an inadequate answer to the question 'what is piety?', since being loved by all the gods is an accidental property (pathos, $E u$. 11a8) of piety, whereas Socrates wants to know its nature or essence", p. 47.

${ }^{20}$ Aristóteles, com seus argumentos, foi um dos maiores críticos da Teoria das Formas platônica. $\mathrm{Na}$ Metafísica, Aristóteles expõe vários desses argumentos, mas sua exposição e crítica será mais detalhada no seu Peri Ideon. O que temos acesso deste texto é o que está conservado nos comentários de Alexandre de Afrodisia à Metafísica de Aristóteles. Entre os argumentos que tentam provar a existência de idéias separadas, existe exatamente este mesmo argumento, "um de muitos". A fórmula do Argumento Um de Muitos se apresenta da seguinte forma, como está exposto no texto de Fine (1993), (p. 104):

(1) Whenever many $F \mathrm{~s}$ (polla) are $F$, they are $F$ in virtue of having some one thing, the $F$, predicated of them.

(2) No $F$ particular (kath' hekaston) is $F$ in virtue of itself.

(3) The $F$ is in every case (aei) predicated in the same way of all the numerically successive Fs (ton kat' arithmon allassomenon).

(4) Therefore the $F$ is something besides (para) particular $F$ s.

(5) Therefore the $F$ is separated from kechorismenon) particular $F$ s and is everlasting (aidion).

(6) Whatever is a one over many, separated, and everlasting is a form.

(7) Therefore the $F$ is a form.

Esta mesma estrutura, com pouquíssima diferença, será apresentada por Fine em seu texto “The One Over Many". 
valendo-se dos outros Diálogos. Com isto, vamos expor os exemplos dos outros e comparar com o que é apresentado no Protágoras 329C. No Laches, a partir de 191C, Sócrates tenta dar indicações de como Laques deve proceder, exemplificando vários domínios em que a Coragem pode estar presente (191D). Mas nesses mesmos domínios podemos encontrar tanto a Coragem quanto covardia. Sua questão agora pousa sobre essas duas coisas, e seu objetivo, então, é descobrir o que é cada uma delas. Antes, o interesse de Sócrates é a Coragem, por isso que seu pedido é que Laques inicie a tentativa de dizer o que ela é. Para tanto, o que é preciso em tal tarefa é o critério "um de muitos": "tente, novamente, dizer, começando pela Coragem, em que ela é identica [tauton] em todos os seus casos". Seguindo a indicação dada por Dorion, ${ }^{21}$ iremos encontrar isto também no Eutífron (5D) e no Mênon (72C). Mas o que Dorion indica nessas passagens é a recorrência ao termo que corresponde à "semelhança" relacionado com o argumento. Temos também as seguintes passagens do Mênon relacionadas a este argumento: 77A; 73E e 75A.

Ao examinarmos o Eutífron (5D), vemos Sócrates expressando a seguinte fórmula: "o pio não é idêntico [tauton] a si mesmo em toda ação [en páse práksei]"(grifos nossos). Em todas e múltiplas ações pias, existe uma única coisa em todas elas. Observamos aqui também que existe este contraste entre o "um", o pio que é idêntico a si mesmo, e os "muitos", que são todas as ações pias, isto é, a oposição do um entre muitos (77A), do que segue que o desejo dele não é uma virtude mas a virtude (73E), esta que é a mesma em todos os Xs (75A).

${ }^{21}$ Dorion (1997) declara o seguinte: "Cf. aussi Euthyphron 5d et Ménon 72c, où Socrate formule également la même exigence, celle de degager la caractéristique genérale qui est commune à toutes les manifestations particulières d'une vertu et qui fait que toutes ces manifestations, aussi disparates qu'elles puissent sembler à première vue, sont précisément des exemples d'une seule et même vertu", nota 134. 
Mas algo precisa ainda ser discutido. Existem dois tipos deste argumento, ele se divide em semântico e realista. O argumento realista um de muitos (postula universais para explicar a igualdade de natureza, isto é, se um grupo de objetos são todos $\mathrm{F}$, eles são todos $\mathrm{F}$ por compartilhar uma propriedade genuína). E o argumento semântico um de muitos, que postula universais para explicar os significados dos termos gerais e, certamente, universais são somente os significados destes termos. Para Fine, entre estes dois tipos, aquele que é desejado por Platão é exatamente o primeiro, o realista. Segundo ela, Sócrates não desejava saber o significado dos termos gerais, mas aquilo em virtude do qual as coisas são o que são.

\subsubsection{O critério “o que $X$, ele mesmo, é" (X-ele-mesmo)}

Se um dos critérios para se chegar à essência de X é a distinção da única coisa que é a mesma, idêntica a si mesma, nas que são múltiplas, ou melhor, que compõem o mesmo grupo - o que ficou conhecido como argumento "um sobre vários" - o próximo é o critério que chamaremos de X-ele-mesmo, que consiste na procura por esse $\mathrm{X}$ que é idêntico a si mesmo e que é o mesmo nos vários Xs - pretendemos pôr este critério como conseqüência e o objetivo (lugar onde se quer chegar) do primeiro. Este critério pode ser apresentado de duas outras formas de grande importância para explicar a natureza das questões socráticas:

1) O uso da palavra eidos ou Forma;

2) O significado da palavra ousia, ser ou essência. 


\subsubsection{O uso das palavras eîdos, idéa ou forma ${ }^{22}$}

Antes de tudo, uma questão terminológica: é necessário estabelecer a diferença que é feita entre a Forma socrática e a Forma platônica. Para a nossa discussão, por enquanto, o que nos interessa é a Forma socrática.

Platão e Sócrates estavam imersos dentro da cultura de sua época e, portanto, de sua língua. O uso que eles fazem destes termos, em essência, não foge do sentido natural. Assim, para marcar a distinção entre estas duas formas, destacamos o emprego filosófico e especializado que é dado a cada uma. Desta forma, consideramos o período socrático dos escritos de Platão e o período platônico propriamente dito para empregarmos corretamente o sentido real de cada "Forma". Com isto temos:

1. o eîdos socrático, que mantém o mesmo significado original deste termo, a saber, caráter distintivo, forma geral, aspecto exterior. A forma socrática seria este eîdos que um grupo de coisas possui. Ele seria o que existe de comum ou idêntico entre estas coisas, e que graças a ele recebem a mesma denominação. Por exemplo, se temos a Sabedoria, Justiça, Piedade, Temperança e Coragem, todas fazem parte de um único grupo e recebem uma única denominação, a saber, "virtude". O eîdos destas virtudes é exatamente isto que elas tem em comum, que é o fato de serem todas virtudes. O eîdos das virtudes é a Virtude.

\footnotetext{
${ }^{22}$ No valeremos do Eutífron 6D-E para considerarmos ê̂dos e idéa como termos sinônimos, justamente porque estes termos foram aplicados de forma a servir como termos intercambiáveis. Assumimos tal posição tendo por base a seguinte declaração de Dorion (1997): “dans l'Euthyphron, Platon emploie indifféremment ê̂dos et idéa, c'est-à-dire qu'il les regarde comme de parfais synonymes. Au reste, le passage 6d-e montre bien que ces deux termes sont interchageables", n.81, p.209.
} 

etc.) tem como diferença marcante o fato de ser uma realidade não sensível, separada das coisas sensíveis, e que lhes determina seu grupo ou classe através da relação de participação ou imitação. $\mathrm{O}$ ê̂dos socrático não tem esta carga ontológica nem apresenta, também, uma característica peculiar destas Formas platônicas que seriam as duplas de opostos (ser-devir, imutabilidade-mudança, imperecível-perecível, inteligível-sensível etc.). Estas duplas de opostos marcará a separação entre o que é real, verdadeiro, inteligível do que é imperfeito, sensível, falso, cópia imperfeita.

Como nosso trabalho se limita ao estudo dos Diálogos socráticos, consideremos apenas a Forma socrática. O Eutífron é onde vamos encontrar Sócrates, explicitamente, mencionando esta Forma que ele tem em mente:

"Lembre-se, então, que não te exortei isto: ensinar-me uma nem duas das várias coisas piedosas, mas aquela forma mesma $[\hat{\imath} \hat{d} o s]$ pela qual todas as coisas piedosas são piedosas?"

A Forma socrática que está exposta aqui no Eutífron apresenta este caráter geral, ou ềdos, da Piedade que é comum a todas as coisas pias. É por este modelo ou eîdos das coisas pias que Eutífron deve encontrar esta forma única que faz com que as coisas pias sejam pias. Porém, não é porque as coisas pias são pias que é permitido, por esta forma única, que ela seja considerada tal qual as Formas inteligíveis dos Diálogos platônicos. Dorion nos dá uma justificativa razoável: "não se trata do modelo que tende a imitar as coisas sensíveis, e por relação ao qual estes aqui são, aliás, delineados, mas tudo simplesmente do modelo que, à maneira de um critério, permite julgar a partir da conformidade, ou não, do sensível à essência determinada segundo esta norma (...) é um 
universal, mas a este eîdos não está atada nenhuma das dimensões ontológicas e epistemológicas da teoria das formas inteligíveis". ${ }^{23}$ Esta última declaração é fundamental, mas nos reservamos de declarar qualquer coisa neste momento. Dixsaut, contra Dorion, apresenta uma contra argumentação que nos parece bem mais sustentável. Ela diz: 'L.-A. Dorion afirma que 'esta variedade de causa não trata do exterior sobre a coisa a qual ela comunica sua natureza' e que se trata de 'uma causa puramente lógica', imanente, que é necessário se guardar para não confundir 'com a causalidade ontológica e transcendente que exercem as formas inteligíveis nos diálogos de maturidade', portanto, de uma história completamente outra”. Ora, primeiramente, trata-se para Platão de uma mesma história, ou mais ainda de um mesmo problema, aquele da possibilidade de pensar, portanto, a existência dos objetos pensáveis". ${ }^{24}$

\subsubsection{O significado da palavra ousia (ser ou essência)}

O sentido de essência que tomaremos será o que aparece em Eutífron 11A: "Eutífron, nota-se bem que tu não me quis revelar a essência, e que tu não me tens

${ }^{23}$ Dorion (1997): “il n'est s'agit pas du modèle qui tendent à imiter les choses sensibles, et par rapport auquel celles-ci sont d'ailleurs façonnés, ma is tout simplement du modèle qui, à la façon d'un critère, permet de juger de la conformité, ou non, du sensible à l'essence déterminée d'après cette norme (...) c'est un universel, mais à cet eîdos n'est attachée aucune des dimensions ontologiques et épis témologiques de la théorie des formes intelligibles”, p. 211.

${ }^{24}$ Estas considerações de Dixsaut (2001) serão apenas suscitadas. Não pretendemos discutir as conclusões a que chega esta pesquisadora: “L.-A. Dorion affirme que «cette variété de cause n'agit pas de l'extérieur sur la chose à laquelle elle communique sa nature» et qu'il s'agit d' «une cause purement logique», immanente, qu'il faut se garder de confondre «avec la causalité ontologique et transcedente qu'exercent les formes intelligibles dans les dialogues de la maturité», donc «d'une toute autre histoire». Or tout d'abord, il s'agit pour Platon d'une même histoire, ou plutôt d'une même problème, celui de la possibilité de penser, donc de l'existence d'objets pensables", p. 30. 
indicado senão um acidente". A passagem revela que existem qualidades, no que Eutífron expôs, que não fazem parte da essência da Piedade. "Ser amado por todos os deuses" não é capaz de fazer com que as coisas pias sejam pias.

Existe uma distinção entre essência nominal e essência real que está relacionada, respectivamente, a definição nominal e real. Levaremos isto em conta, mas será matéria discutida mais a frente.

\subsection{A prioridade epistemológica da definição}

Sócrates afirma em alguns Diálogos que antes mesmo de atribuirmos qualquer qualidade à coisa investigada, não podemos afirmar com exatidão que tipo de coisa é $\mathrm{X}$ até que tenhamos respondido, corretamente, o que X é. Se é necessário, anteriormente, a descoberta do que é $\mathrm{X}$ então responder a questão socrática deve ser a prioridade na investigação. Não podemos saber se a virtude pode ser ensinada ou não até que tenhamos respondido o que é a virtude (Men. 71, 86 d-e, 100b; Prt. 360e); "Justiça é uma virtude", não é uma declaração que pode ser dita com acerto até que seja respondida a pergunta “o que é a Justiça?” (Rep. I, 354c). Outro exemplo é o Laches 189e-190a.

Robinson utiliza-se de uma passagem do Lysis (final do Lysis) para fazer a seguinte declaração: "isto é surpreendente, porque parece implicar que, até que tu saibas o que é X, tu não podes dizer se este é um caso de X". ${ }^{25}$ O que Robinson ressalta é que o que existe de extraordinário nesta afirmação é que nada poderia ser afirmado sobre $\mathrm{X}$, exatamente nada, incluindo o poder saber, no sentido mais ordinário de termo, enquanto este X não tiver sido encontrado. Outra passagem é o Eutífron (6e), e provavelmente

\footnotetext{
${ }^{25}$ Robinson (1953): "this is suprising because it seems to imply that until you know what X is you can never say whether this is a case of X", , p. 51.
} 
uma das mais importantes passagens, em que determina que é somente através do eîdos da piedade que podemos saber o que é pio e o que não o é.

\subsubsection{Paradoxo da prioridade epistemológica da definição}

Sócrates pede para seus interlocutores que eles respondam às suas questões, seja a questão “X é Y?”, seja a questão “o que é X?". A questão “o que é X?" é, por excelência, a prioridade epistemológica da definição. Mesmo que a questão primária de Sócrates seja do tipo “X é Y?”, ele cai na exigência da prioridade epistemológica do que é X. Desta forma, se importa para Lisímaco e Melésias saber se é fundamental ou não para a boa educação de seus filhos que eles possuam a Coragem, é necessário, antes de tudo, saber o que é a Coragem. Logo, o seguinte passo de Sócrates é encontrar este X. Ou bem ele já parte da questão o-que-é-X? e tentar encontrar imediatamente este X, ou bem ele parte da questão X-é-Y? para se chegar em o-que-é-X? e dela encontrar o X. Anteriormente, a qualquer tentativa de exprimir se tal qualidade ou tal outra condiz com $X$, é necessário dizer o que era esse $X$. Conclui-se que se não soubermos o que é $\mathrm{X}$ não poderemos, também, saber quais são seus atributos. Porém, para se chegar a uma definição do que é X, é preciso que nós utilizemos de uma série de palavras que revelam ser atributos deste $\mathrm{X}$.

Concordamos com Fine quando faz a seguinte declaração a respeito da prioridade epistemológica da definição: “uma vez que nós compreendemos o tipo de definição que Sócrates deseja, nós podemos também entender por que ele acredita que nós necessitamos saber a definição de $\mathrm{F}$ de forma a saber qualquer coisa sobre $\mathrm{F}$, incluindo quais coisas exemplifica F. Ele não quer dizer que nós necessitamos saber a definição de F de forma a ter opiniões sobre F; pelo contrário, ele acha que temos 
opiniões, mesmo opiniões verdadeiras, sobre F, embora não saibamos o que F é. Ele quer dizer que mós necessitamos saber a definição de F para sabermos qualquer coisa sobre F. Pois a definição de F explica o que ele deve ser; e do ponto de vista de Sócrates, qualquer conhecimento sobre F, incluindo o conhecimento de quais coisas são F, requer tais explicações. Nós podemos corretamente acreditar que uma ação particular é justa sem saber o que justiça é. Portanto, como Aristóteles disse, Sócrates estava procurando a essência, ou o que uma coisa é, e ele acreditou que tal conhecimento era necessário para qualquer conhecimento, não importa qual". ${ }^{26}$ Estas declarações de Fine, além de tratar da questão da prioridade epistemológica, apresenta pontos importantes para a nossa investigação. Ela apresenta a relação entre prioridade epistemológica da definição e o que trataremos mais a frente como o critério de verdade da investigação socrática.

Mas a prioridade epistemológica da definição aparenta ser um paradoxo: só podemos falar de alguma coisa $\mathrm{X}$ se soubermos o que é $\mathrm{X}$, e para sabermos o que é $\mathrm{X}$ precisamos observar, nas formas particulares que estes $\mathrm{X}$ se apresenta, o que elas possuem de comum, no entanto, como podemos identificar as formas particulares, se antes de tudo precisamos encontrar o que é $\mathrm{X}$ ?

\footnotetext{
${ }^{26}$ Fine (1993): "once we understand the sort of definition Socrates wants, we can also understand why he believes that we need to know the definition of $\mathrm{F}$ in order to know anything about to $\mathrm{F}$, including what things instantiate F. He does not mean that we need to know the definition of $\mathrm{F}$ in order to have beliefs about F; on the contrary, he thinks that we have beliefs, even true beliefs, about $\mathrm{F}$ although we do not know what $\mathrm{F}$ is. He means that we need to know the definition of $\mathrm{F}$ to know anything about $\mathrm{F}$. For the definition of F explains what it is to be F; and in Socrates' view, any knowledge about F, including knowledge of what things are F, requires such explanations. We can correctly believe that a particular action is just without knowing what justice is. Hence, as Aristotle says, Socrates was seeking the essence, or what a thing is, and he believed that such knowledge was necessary for any knowledge whatsover", p. 49.
} 


\subsubsection{A importância da prioridade epistemológica da definição}

Uma possível saída para esse paradoxo é apresentada por Robinson. A insatisfação por parte de Sócrates revela uma insatisfação quanto à determinação do que está sendo respondido, ou seja, não se trata de observar os casos ou exemplos de X. Não é a via certa que deve ser tomada, tanto que Sócrates sempre repreende tais respostas. Isso se explica porque não são os casos ou exemplos de $\mathrm{X}$ que são importantes, mas sim o X-ele-mesmo.

Robinson aponta uma possível resposta para este paradoxo, o que nós mesmos nomearemos mais adiante de "critério de verdade", quando afirma que nos primeiros Diálogos "Sócrates pensa que não existe qualquer verdade sobre $\mathrm{X}$ que possa ser conhecida antes que nós saibamos o que X é". ${ }^{27}$ Concordando com a passagem anterior, encontramos uma outra que expressa a teoria de que não existe verdade anterior de $\mathrm{X}$ no sujeito que investiga, porque só existem nele opiniões mais ou menos prováveis deste X. Aqui, precisamos determinar qual o tipo de verdade e qual o tipo de opinião. Esta nossa tarefa se reservará para a seção concernente à discussão do elenchos.

Temos um conhecimento anterior, que não é o conhecimento de $\mathrm{X}$, e que nos permite saber, reconhecer ou conhecer quais são os casos ou exemplos de X. Este tipo de conhecimento é o que Robinson chama, nesta seguinte citação, de opinião. É ela que nos permite identificar uma característica $\mathrm{Y}$ que pertence a $\mathrm{X}$, mas que não nos assegura a certeza de tal coisa: "antes de verificar o que $\mathrm{X}$ é, ele parece pensar, nós podemos formar opiniões mais ou menos prováveis que $\mathrm{X}$, qualquer que ele deva ser, possui a

\footnotetext{
${ }^{27}$ Robinson (1953): "Socrates thinks that there is no truth whatever about X that can be known before we know what X is", p. 51
} 
característica Y, mas nunca podemos estar certos de tal coisa". ${ }^{28}$ Como conclusão, que achamos muito razoável e compartilhamos dela, Robinson afirma que "o princípio é oferecido como auto-evidente e óbvio demais para a discussão". ${ }^{29}$ Para este momento, estaremos satisfeitos com estes resultados. O Mênon, assim como a passagem do Fedro (260), apresenta um excelente argumento que prova a possibilidade de iniciar uma investigação com a exigência da prioridade epistemológica da definição sem estarmos em um paradoxo sem saída.

\subsection{Crítica da questão o-que-é-X?}

Para a questão primária socrática “o que é X?", temos uma resposta do tipo “X é Z”, de tal forma que todo $\mathrm{X}$ deve ser necessariamente $\mathrm{Z}$ e nada mais. Se, no entanto, a esfera de $\mathrm{Z}$ ultrapassa $\mathrm{X}$, de modo que uma parte de $\mathrm{Z}$ é $\mathrm{X}$, já que $\mathrm{Z}$ se estende a outras coisas além de $\mathrm{X}$, podemos afirmar que $\mathrm{X}$ não é equivalente a $\mathrm{Z}$ por motivo de que a noção de $\mathrm{Z}$ é mais ampla do que $\mathrm{X}$. Com base nisto, Robinson conclui que Sócrates procura equivalências. Porém, o que significa dizer que o objetivo de Sócrates é a busca por equivalências? Sabemos que uma discussão entre os comentadores, e muitas vezes é os faz divergirem, é quanto ao tipo de objetivo que Sócrates tem em mente quando utiliza suas famosas questões. A divergência é se este objetivo seria a busca por universais, ou essências, ou significados, ou definições ou outra coisa qualquer. Penner crê que Sócrates não procurava nem universais, nem essências, nem definições. Crombie, por sua vez, pensa que a "definição socrática não deve ser geralmente pensada

\footnotetext{
${ }^{28}$ Robinson(1953): "Prior to ascertaining what $\mathrm{X}$ is, he seems to think, we can form more or less probable opinions that $\mathrm{X}$, whatever it may be, possesses the character $\mathrm{Y}$, but can never be certain of such a thing (cf.Tht. 196DE)", p. 51.

${ }^{29}$ Robinson (1953): "the principle is offered as self-evident and too obvious for discussion", p. 51.
} 
como um convite para definir X" e completa, "uma questão é um pedido por um desempenho".30

\subsubsection{A imprecisão e as dificuldades da questão o-que-é-X?}

A questão o-que-é-X? apresenta uma determinada dificuldade que muitos dos interlocutores de Sócrates não percebem. Isto porque, de prontidão, eles estão dispostos a responder esta questão sem a mínima hesitação. Tais pessoas não hesitam ao responder às perguntas de Sócrates por conta da imprecisão deste tipo de pergunta oque-é-X?. Por seu caráter de imprecisão, os interlocutores se propõe à tarefa solicitada sem hesitar.

Existem duas formas que estão entre os extremos do tipo de pergunta que servem como pedidos para o esclarecimento de alguma coisa que o inquiridor deseja. Elas se estendem da mais precisa, isto é, quando a questão revela de imediato qual é seu objetivo, até a mais imprecisa nessa tarefa, quando a questão permite que o respondente vaguei na resposta. Estes dois extremos são as duas formas X-é-Y?, para questão mais precisa, e a forma o-que-é-X?, para questão mais imprecisa.

Entre estas formas de se fazer um pedido por uma informação sobre um determinado objeto, a mais precisa é a forma X-é-Y?. Se Sócrates questiona se a Coragem é bela, o respondente precisa somente responder que é bela ou que não é bela. Em grau de precisão, as formas onde-está-X? e quando-é-X? comparadas a esta anterior

\footnotetext{
${ }^{30}$ Crombie: "Socratic definition should not be generally thought of as an invitation to define X...a question is a request for a performance", p. 177. Crombie faz uma distinção entre respostas apropriadas e respostas corretas para se fazer a crítica à questão o-que-é-X?. Ao que parece, para Combrie, Sócrates procurava respostas corretas para as suas questões, porém, só encontrava respostas apropriadas. Se tomarmos o Mênon, veremos que a Virtude é definida como uma episteme e, em outro momento, como uma doxa verdadeira. Tais respostas são apropriadas, mas não são corretas. Como Crombie se expressa, essas respostas estão na rota certa para se chegar às respostas realmente corretas.
} 
são menos precisas, pois tal pergunta solicita que um determinado tempo ou determinado lugar desejado seja expresso. Não se trata de solicitações extremamente imprecisas como a data certa em que Jesus nasceu ou da extinção dos dinossauros, nem se algo acontecerá daqui a alguns minutos ou vários anos. Mais vaga ainda é a forma por-que-X?, pela inúmera e indefinida quantidade de fatos que são casos, razões ou explicações de qualquer fato. A mais imprecisa de todas é a questão o-que-é-X?. Sua imprecisão é devida ao número indeterminado de declarações, verdadeiras ou não, que podemos fazer acerca de X. Quando Sócrates pergunta “o que é a Virtude?”, ele pode receber como resposta vários tipos diferentes de proposições. Daí que, Mênon responde dando uma série de exemplos de virtudes, quais são os tipos, em que ela se encontra, se é bela etc. A imprecisão destas questões pode ser reduzida valendo-se do contexto em que elas estão inseridas.

Por ser a mais vaga de todas, a questão o-que-é-X? determina uma coisa. Tal questionamento pode receber todo tipo de proposição, já que suscita toda a extensão de X. Como sugere isso, é necessário, quando o contexto não permitir, expressar o todo de $\mathrm{X}$. Ao mesmo tempo em que ela dificulta a procura pelo objeto, ela é a melhor entre as outras por conseguir expressar esse pedido pelo todo de $\mathrm{X}$, ou melhor, pela essência de $\mathrm{X}$.

\subsection{Tipos de definições}

Agora que sabemos que as "Formas socráticas" é o que Sócrates persegue, sabemos, portanto, que as respostas para as suas questões primárias devem ser estas Formas. 
Valendo-se do testemunho de Aristóteles, muitos estudiosos foram levados a observar que o esforço de Sócrates (nos Diálogos socráticos) em sua pesquisa é a busca por definições. Nossa posição não é diferente. Pretendemos, da mesma forma, mostrar que as pretensões de Sócrates eram as definições dos seus objetos de investigação. Por uma outra linha de interpretação, veremos I. M. Crombie defendendo uma tese de que o objetivo da investigação socrática não visava encontrar estas definições. Combrie ressalta que esta interpretação, ao invés de iluminar o pensamento socrático-platônico, induz ao erro.

Antes mesmo de entrarmos na questão de compreender se Sócrates buscava ou não a definição dos pontos suscitados no início da investigação, faz-se necessário saber que tipo de definição Sócrates estava disposto a empregar. Pensando em definições, elas podem ser classificadas em: nominais, também chamadas de lingüísticas, verbais, ou reais. Dizer simplesmente que Sócrates procurava definições se torna muito vago. Mas podemos assegurar que Sócrates procurava por aquilo que lhe era desconhecido, o que é a base ou o que todos estes tipos de definição tem em comum, a tentativa de revelar isto que está oculto. Portanto, Sócrates procurava por aquilo que ele não conhecia. Podemos assumir que a procura de Sócrates é pela essência das coisas, e isto pode ser alcançado pela definição que é a descrição que nos assegura alcançar este objetivo; ela mesma não é X, mas acaba revelando sua essência. Procurava uma definição que possibilitasse tornar conhecido este objeto. O problema é: qual tipo de definição?

\subsubsection{Definição Verbal ou Lingüística}

Listar exemplos com o objetivo de dar uma resposta à pergunta socrática não é o procedimento mais adequado. Citar os tipos particulares de $\mathrm{X}$ corresponde ao que 
Sócrates declara como "acidental" em Eutífron 11a. Dar uma série de exemplos é o mesmo que dar uma definição nominal, "uma definição que simplesmente lista os vários Fs deve ser, na melhor das hipóteses, uma definição nominal, a qual nos diz que certas coisas são $F$ ou são convencionalmente classificadas como $F$ s". ${ }^{31}$ Este tipo de classificação ou de listar tipos de Xs não nos permite dizer porque eles são X e, portanto, se um tipo é ou não pertencente ao grupo $\mathrm{X}$, nem mesmo podemos dizer se estamos fazendo uma classificação correta.

Se assumirmos que o que Sócrates almejava como respostas ideais para suas questões era a definição verbal, deveríamos assumir que o critério de verdade estaria abalado e a investigação socrática seria completamente sem importância filosófica. Isto porque, como afirmamos anteriormente (seção II 1.2.2), existem conhecimentos que podem ser verdadeiros ou falsos sobre as coisas, e que merecem passar pela investigação para receber o status de conhecimento científico. Não se trata de uma investigação por palavras que são desconhecidas. Sócrates não procurava um uso ordinário destes termos. Ele desejava saber como realmente são essas coisas que ele investiga. Fine diz: "as definições socráticas são reais ao invés de definições nominais" (p. 48).

Definição nominal é o tipo de definição que aparece em um dicionário, como afirma Irwin. As definições nominais são de fundamental importância porque sem elas não é possível uma comunicação clara e efetiva caso não saibamos os significados das palavras, "nós devemos argumentar em mme de Sócrates que as definições nominais são necessárias porque nós não podemos comunicar claramente ou efetivamente se nós não compreendemos o significado de nossas palavras, e nós não podemos compreender

\footnotetext{
${ }^{31}$ Fine (1993): "A defintion that simply listed the many $F$ s would be at best a nominal definition, tell us that certain things are $F$ or are conventionally classified as $F$ s", p. 48.
} 
isto se nós não podemos dar definições". ${ }^{32}$ Parece um círculo vicioso. É necessário para uma comunicação entre indivíduos que saibamos qual o significado das palavras que estamos usando, porém para sabermos o que cada palavra é, sua definição é necessária. Uma crítica antiga a isto é a de Theopompus, o orador. Segundo ele, não é necessário, para se haver uma conversa que as partes tenham a total compreensão dos termos empregados.

Sempre que vários $F s$ são $F$, eles são $F$ em virtude de ter um único predicado, $F$, como predicado deles. Se isto é possível de ser pensado, então é possível que este $\mathrm{X}$, que é o predicado de todos os Xs, seja um predicado lingüístico. Resta saber se este predicado X corresponde à essência de X. Sabemos que existem formas, assim como predicados gerais abstratos, e que cada uma delas se difere uma das outras; além disso, $\mathrm{X}$ pode ser ou Forma ou predicado geral abstrato. Se X é o predicado de todos os Xs, X seria uma predicação lingüística. Por isso, Forma e predicado geral abstrato seriam, também, predicações lingüísticas. Porém, as Formas e o predicado geral abstrato não são predicados lingüísticos, a forma ou predicado geral abstrato do homem não é o predicado "homem". Com isto, acreditamos que Sócrates não procurava definições nominais, ou lingüísticas, ou algum termo semelhante. Sua definição não buscava a essência nominal, mas outro tipo de essência.

\subsubsection{Definição Real.}

Uma definição real é do tipo que tenta captar a essência, neste caso, real das múltiplas coisas. Tentar fazer isso inclui, também, a eliminação de tudo que seja

\footnotetext{
${ }^{32}$ Irwin (1995): "we might argue on Socrates' behalf that nominal definitions are needed because we cannot communicate clearly or effectively if we do not grasp the meaning of our words, and we cannot grasp this if we cannot give definitions", p. 26.
} 
acidental. Com isso, quando tentamos dar uma definição real de ouro devemos especificar tudo aquilo que lhe é inerente, ao invés de tudo que lhe é "acidental" (cor, brilho, tamanho etc.). A definição real deve capturar o caráter distintivo que algo deve ter para ser considerado como ouro. Ela deve explicar o que o ouro realmente é ao invés de considerar o que comumente significa "ouro".

Consideremos a seguinte declaração de Irwin: [1] "se Sócrates está procurando por definições reais deste tipo, então Aristóteles está certo em supor que ele está procurando pelos tipos de definições que Aristóteles considera como a base do conhecimento científico." [2] "neste caso, Sócrates pode aceitar a resposta de Epicteto à crítica de Teopompus da pesquisa por definições. Epicteto concorda que podemos falar, significativamente, sobre $F$ s, sob a luz de nossas pré-concepções (opiniões intuitivas) sobre $F$, mesmo isento de uma explicação científica; ele argumenta, contudo, que nós não podemos 'aplicar nossas pré-concepções' corretamente até que nós as articulemos por intermédio de uma explicação científica (Epictetus, Diss. II 17.7-11)". ${ }^{33}$ Nesta declaração de Irwin encontramos pontos importantíssimos, pois ele estabelece uma ligação entre a Definição Real e dois pontos fundamentais, o que trataremos como critério de verdade (fundado em nossas pré-concepções) na investigação socrática, e a base do conhecimento científico. Quanto à base do conhecimento científico, a seguinte demarcação serve para demonstrar esta relação e importância:

1) Aristóteles disse que as formas socráticas são a mesma coisa que universais;

\footnotetext{
${ }^{33}$ Irwin (1995): "If Socrates is looking for real definitions of this sort, then Aristotle is right to suppose that he is looking for the sorts of definitions that Aristotle regards as the basis of scientific knowledge." [2] "In that case Socrates can accept Epictetus' answer to Teopompus' criticism of the search for definitions. Epictetus agrees that can speak significantly about $F$ s, in the light of our preconceptions (intuitive beliefs) about $F$, even without a scientific account; he argues, however, that we cannot 'apply our preconceptions' correctly until we articulate them through a scientific account (Epictetus, Diss. II 17.7-11)”, p. 26.
} 
2) Sabemos que essas Formas socráticas são as reais essências das coisas;

3) As essências das coisas são seus universais;

4) A Forma da Piedade está, ao mesmo tempo, em toda coisa que é pia, logo ela é o universal e, também, a essência real das coisas pias;

5) Determinar que o universal é aquilo que está ao mesmo tempo em toda coisa se encaixa perfeitamente nas considerações de Aristóteles sobre os universais;

6) Para Aristóteles duas coisas devem ser atribuídas a Sócrates: argumentos indutivos e definições universais. Portanto, a essência real das coisas pias, a Piedade, é um universal, ;

7) De (6): para Aristóteles estas duas coisas são o ponto de partida da ciência (Met. 1078b23-30);

8) Se Sócrates procurava por definições, ele procurava definições reais. Sendo as definições, segundo Aristóteles, universais, as definições reais são definições universais;

9) A essência real tem por correlato a definição real. Da mesma forma, a essência nominal tem por correlato a definição nominal.

10) Se temos a definição real, por exemplo, da Piedade, por conseqüência temos a essência real da Piedade;

11) As definições universais são o ponto de partida da ciência;

12) Logo, são as definições reais que, por sua vez, são as essências reais como nós vimos que são as definições universais - o ponto de partida da ciência, portanto, do conhecimento.

Nossa conclusão é que Sócrates buscava definições. Estas definições se identificam com as essências das coisas investigadas. Foi demonstrado que Sócrates não 
buscava a definição nominal e, portanto, a essência nominal das coisas investigadas. A busca de Sócrates tinha por fim alcançar a essência real das coisas, logo sua definição real, que é idêntica à essência real. Mas a definição e essência real das coisas é seu universal. Portanto, Sócrates procurava o universal aspirado por sua questão primária, “o que é X?”. Definir X é alcançar o universal X. Esta declaração de Irwin revela o que expusemos: "a essência de F é o universal (não-linguístico) que o estudo de F procura descobrir. Ao dizer que Sócrates procurava definir o universal, Aristóteles implica que Sócrates estava procurando definições reais, já que estas, em contraste às definições, são a base do conhecimento científico". 34

\section{Refutação}

\section{1. considerações preliminares}

Em que momento da argumentação podemos dizer que uma tese foi refutada? Quando ou onde podemos dizer que o interlocutor de Sócrates foi refutado, no decorrer da investigação ou no final, quando este se encontra em dificuldade e, portanto, em aporia? Neste momento, exporemos os elementos que compõem a argumentação socrática, e se estes elementos contribuem para o alcance deste universal, ou essência, ou definição real. Iniciaremos com a exposição do que é o silogismo, partindo deste para tratarmos dos tipos de refutação para, em seguida, discutirmos o que é epagoge.

\footnotetext{
${ }^{34}$ Irwin (1995): "The essence of $\mathrm{F}$ is the (non-linguistic) universal that the study of $\mathrm{F}$ seeks to discover. In saying that Socrates sought to define the universal, Aristotle implies that Socrates was looking for real definitions; for these, in contrast to nominal definitions, ae the basis of scientific knowledge", p. 26.
} 


\subsection{Silogismo}

A palavra silogismo não aparece nos primeiros Diálogos de Platão até os Diálogos intermediários (Cra. 412a e Tht. 186d). O que encontramos é o seu verbo cognato. Nestes primeiros Diálogos, o termo silogismo não alcança o sentido de alguma coisa que está sendo encaminhada até o fim de uma investigação, ou, para nos expressarmos de uma maneira mais adequada, até o fim de um elenchos. Estes Diálogos não teriam a preocupação de pôr todos os fatos juntos a fim de avaliar suas conseqüências, e não teria o sentido próprio que tem o silogismo, que é um argumento em que duas ou mais premissas são colocadas “juntas" para, desta união, serem retiradas as conclusões. O que está de acordo com a definição aristotélica de que "um silogismo é um argumento no qual, estabelecidas certas coisas, resulta necessariamente delas, por serem o que são, outra coisa distinta das antes estabelecidas" (An. Pr., I 24 b 18-23). Porém, tal definição é muito ampla, incluindo muitos outros tipos de inferências. A referência ao silogismo que é apresentada nos Diálogos socráticos apenas exibe os fatos relevantes.

O verbo silogizar cumpre esta função que foi debatida precedentemente na obra de Platão nas passagens do Carmides, Górgias, Protágoras e República I:

encontramos no Carmides: "reúne todos estes elementos [panta tauta sullogisamenoj] e diz-me claramente e bravamente o que ele te parece ser" [160D]. Esta passagem é uma espécie de ponto de chegada do exame da primeira tese suscitada, ou melhor, da primeira resposta dada por Carmides à questão primária socrática deste Diálogo. A definição de Carmides é que a Temperança, em suma, é uma espécie de calma. Sócrates expõe casos em que ser o contrário de calmo demonstra ser uma das partes intimamente relacionadas à Temperança, assim como ser calmo em determinadas 
situações também o é. Ele vai considerar as coisas que estão relacionadas ao corpo e as que estão relacionadas ao espírito, e suas respectivas relações com o ser calmo e o ser vivaz. Tendo verificado estas coisas, Sócrates chega ao sentido que o verbo "sullogizomai" carrega. É claro que Sócrates retira conclusões deste processo de silogizar, porém esta conclusão não é uma nova tese. Foi verificado que a tese de Carmides não alcança seu objetivo, já que existem domínios em que ser calmo escapa à esfera da própria Temperança, ou seja, "nem todo X é A". O que neste caso Carmides precisa fazer é tentar novamente, atendendo aos princípios alcançados de reunir todos estes elementos e de entrechocá-los, dar a definição que atinja a essência, a saber, a Temperança ela-mesma, já que neste entrechoque foi verificado que sua primeira definição não cumpriu este papel. A conclusão, aqui, é que esta primeira definição não cobre totalmente todos os casos particulares que recebem o qualificativo de temperantes.

O mesmo que verificamos no Carmides deve ser verificado nas outras passagens dos Diálogos acima citados. Todos devem apresentar o sentido do verbo cognato ao termo grego syllogismos como uma espécie de conclusão da observação de fatos relevantes, em que esta conclusão não é uma nova tese. Com isto, nas seguintes passagens do Górgias, "mas se nossos princípios são justos, tu vês o que resulta da nossa discussão, ou tu vês que nós retiraremos as conclusões disto [h . boul ei sul l ogismw meqa auta ;]?" (479c), e "Maintenant résume de concert avec moi [sul l ogis a i dh, koinh/met 'emoul] ce qui résulte de ces aveux", (498e), assim como nas passagens de Protágoras, "vamos, eu disse, recapitulemos os pontos sobre os quais nõs estamos de acordo [analogiswmeqa ta, wimologhmena himin]" (332d) e da República I, "E essa pessoa - ou devido à debilidade da velhice, ou porque avista mais claramente as coisas do além, como quem está mais perto delas - seja for a 
verdade, enche-se de desconfianças e temores, e começa a fazer os seus cálculos [analogizetai] e a examinar [skopeid] se cometeu alguma injustiça para com alguém" (330e), encontramos este mesmo sentido para silogismo.

Em linhas gerais o silogismo pode ser apresentado como neste exemplo abaixo: Todos os homens são mortais;

Os gregos são homens;

Logo, os gregos são mortais.

Os silogismos nos encaminham de pontos que nos foram apresentados ou tornados evidentes para conclusões, sejam para positivar uma tese, sejam para demonstrar sua negação ou insuficiência. Desta forma, o silogismo está relacionado com a refutação, direta ou indireta. Robinson declara: "este momento de silogizar, é o momento em que tudo é tornado claro. O propósito das premissas separadas, a forma de colocá-las juntas, e o fato de que elas implicam a falsidade de sua tese, agora se torna evidente para o interlocutor". ${ }^{35}$ Demosntraremos que todo silogismo ou estabelece uma tese de forma direta e nega de forma indireta ou estabelece uma tese de forma indireta e nega de forma direta. Em suma, o silogismo sempre tem uma conclusão positiva e negativa. No nosso exemplo, positivamente foi demonstrado que os gregos são mortais, uma tese neste momento foi estabelecida. Mas negativamente foi demonstrado que eles não são imortais, e aqui temos uma espécie de refutação.

\footnotetext{
${ }^{35}$ Robinson (1953): "this moment of syllogizing is the moment when all is made clear. The purpose of the separated premisses, the way they fit together, and the fact that they entail the falshood of his thesis, now become evident to the answerer", p. 22.
} 


\section{3. refutação direta e refutação indireta}

\subsubsection{Refutar uma tese indiretamente}

Antes de discutirmos o que é uma refutação indireta, vamos considerar que a mesma atende à seguinte regra: "se A, então B; mas, se não b, então não A"; e que seus elementos são:

1. "não A" é a conclusão;

2. “não B” a premissa menor;

3. "se A então B" a premissa maior;

4. B é a falsidade e também a consequiência;

5. A é a suposição e também a tese.

Em linhas gerais, refutar uma tese indiretamente é o mesmo que encontrar sua "falsidade", ou, para nos expressarmos de uma melhor forma, sua insuficiência. Com base nos elementos enumerados acima, A implica B, mas B é insustentável, por conta de “não B”; se "não B”, logo, "não A”. Esta argumentação demonstrou a refutação indireta de A. A definição de Coragem dada por Laques para a questão "o que é a Coragem $[\mathrm{X}]$ ?" é: “se, pois, um homem deseja, permanecendo em seu posto, lutar contra seus inimigos e não foge, esteja certo que será um homem corajoso" [Y] (190e). Porém, existe uma outra forma de Coragem, a fuga [Z]. Se toda Coragem fosse permanecer firme, então, já que a fuga é um tipo de Coragem, fugir deveria ser um ato de permanecer firme em seu posto. Porém, fugir não é o mesmo que permanecer firme; portanto, toda Coragem não pode ser permanecer firme em seu posto. A fórmula neste caso é: Se todo X fosse $\mathrm{Y}$ [A], então, já que $\mathrm{Z}$ é um tipo de $\mathrm{X}, \mathrm{Z}$ deve ser $\mathrm{Y}$ [B]. Porém, $\mathrm{Z}$ não é Y [não B]; portanto, $\mathrm{X}$ não é Y [não A]. Com isso, podemos chegar à seguinte 
fórmula: se $\mathrm{A}$, então $\mathrm{B}$; mas não $\mathrm{B}$, portanto não $\mathrm{A}$. Conclusão: $\mathrm{A}$ foi refutado indiretamente. A tese dada por Laques foi refutada.

\subsubsection{Refutar uma tese diretamente}

A refutação direta é toda e qualquer refutação que não é indireta. É o tipo de refutação que alcança a negação da tese, pressupondo em nenhum momento a mesma, por exemplo: A Coragem é uma coisa bela [A], então, já que a firmeza refletida é um tipo de Coragem, a firmeza refletida deve ser uma coisa bela [B]. Temos aqui uma refutação direta da firmeza irrefletida, o que pode ser apresentado na seguinte fórmula: “A, portanto B". Tal forma demonstra a refutação direta de não-B, onde não-B, no nosso exemplo, é a firme za irrefletida.

\subsection{Epagoge}

Por epagoge trataremos apenas dois tipos distintos, mas que, em essência, apresentam a mesma estrutura lógica. São estes:

1) A indução dos casos particulares para seu universal, neste caso temos os trechos do Laches (191d-192b), em que Sócrates sugere a Laques que procure nos diversos casos de Coragem o que eles têm de idêntico e exemplifica com o caso da velocidade, e temos a passagem do Eutífron (6de), em que Sócrates pede para que Eutífron identifique o único carater distintivo das coisas pias para que ele possa encontrar a forma socrática da Piedade. 
2) A indução dos menos universais para um mais universal. Os melhores exemplos desse tipo de epagoge são o Carmides (159b-161b): as duas respostas de Carmides à questão “o que é a Temperança?”, das quais, apesar de ter se aproximado da exigência recorrente de Sócrates de uma resposta a mais universal possível, mostraram-se mais sofisticadas do que aquelas que são apresentadas nos outros Diálogos que sempre dão como respostas tipos de atos virtuosos - já são por si mesmas universais, “Temperança é Calma” (159b) e "Temperança é Pudor" (160e). Mas através delas, ou melhor, da negação delas, Carmides percebe que estas respostas, apesar de serem temperantes, ultrapassam a esfera da própria Temperança, em alguns pontos cobrindo ações que não são temperantes, e em outros não cobrem ações propriamente temperantes. Daí que se sente a necessidade de se encontrar um tipo de resposta que cubra todos os atos temperantes, um tipo mais universal, e Carmides desta vez define a Temperança como "exercer sua própria função" (161b); e no Eutífron (11e12d): Sócrates põe a Piedade como parte da Justiça, e para ressaltar a relação entre entre estes dois universais, ele demonstra dois exemplos análogos, os quais interpretamos como a maneira correta de como deve ser considerada toda relação entre os universais e o universal mais desenvolvido, que é o todo destes mais particulares - a relação entre Temor e Respeito (12a-b) e a relação entre o Par/Impar e o Número (12c). A Piedade e a outra parte da Justiça são as partes menos universais da Justiça, que é mais universal que suas partes. 
Os casos mais comuns que podemos observar sendo utilizados nos diálogos são os de inferência de proposições para uma proposição superordinada, isto é, dos casos para o universal. O exemplo dado por Robinson é o Protágoras (332c):

“Agora, eu disse, uma tal coisa que a beleza? - ele concordou - existe alguma coisa oposta a ela exceto a fealdade? - Não - E sobre isto? existe uma tal coisa como a bondade? - Sim - existe qualquer coisa oposta exceto a maldade? - não existe - e sobre isto? Existe uma tal coisa como o tom alto da voz? - ele disse existir - se existir qualquer coisa oposta a ele a não ser tom baixo? - não existia, ele disse - então, eu disse, para cada um único oposto tem um e somente um único oposto? - ele concordou".

O que existe de idêntico entre estes dois tipos de epagoge que apresentamos é que eles partem dos particulares ou dos menos universais para o mais universal, valendo-se do que existe de comum entre este particulares ou menos universais.

\subsection{Método Elênctico}

Nos Diálogos socráticos, usualmente o método argumentativo está baseado numa interrogação sistemática que incide nas opiniões, ou melhor, nas teses sustentadas pelos interlocutores de Sócrates, as quais são as respostas a estas interrogações. Esta interrogação tem por instrumento principal a refutação das teses suscitadas. Tal método de refutação que Sócrates utiliza contra seus oponentes passou a ser chamado Método Elênctico.

Esse termo methodos não foi pensado, nem usado conscientemente, nem discutido por Sócrates, enquanto personagem de Platão, nestes Diálogos. O que vemos ser utilizado é o termo elenchos, do qual Sócrates se vale apenas de sua função 
refutativa, sem determiná-lo ou nomeá- lo como um método propriamente dito, como testemunha Vlastos: "num contraste marcante ao 'Sócrates' que fala por Platão nos Diálogos intermediários, que faz freqüentemente referência ao 'método' (megodoj) que ele segue (ou sistematicamente, ou por algum propósito particular em um contexto especial), o 'Sócrates' que fala por Sócrates nos primeiros Diálogos de Platão nunca usa esta palavra e nunca discute seu método de investigação. Ele nunca se preocupa em dizer porque sua forma de pesquisa é a forma de descobrir a verdade ou ainda em dizer o que esta forma de pesquisa é. Ele não tem um nome para isso. 'Elenchos' e o verbo cognato, elenchein (refutar, examinar criticamente, censurar), ele usa para descrever, não para batizar, o que ele faz". ${ }^{36}$ Como acabamos de observar, a discussão sobre método apenas aparecerá a partir dos Diálogos intermediários; tal discussão não acontece nos primeiros, já que não existe nenhuma alusão de Sócrates ao método que ele próprio aplica. Algo que denuncia isso é o fato de que, como observam muitos comentadores, Sócrates nunca se encarrega de investigar ou justificar as regras das quais ele se utiliza no decorrer da própria investigação. Em nenhum momento, nestes primeiros Diálogos, ele se utiliza do nome "método" nas suas exposições, nem discute qual seria aquele que deve ser aplicado, muito menos o porquê de sua aplicação.

A estrutura do elenchos é basicamente esta: Sócrates inicia com sua questão primária que pode tanto assumir a forma “o que é X?" quanto a forma "X é Y?”, o interlocutor responde a esta questão primária assumindo uma tese $p$; tendo por base esta tese $p$, Sócrates lança algumas questões, ou seja, recorre a premissas extras $q$ e $r$, para

\footnotetext{
${ }^{36}$ Vlastos (1983), p. 36-37: “in marked contrast to the 'Socrates' who speaks for Plato in the middles dialogues, who refers frequently to the 'method' (megodoj) he follows (either systematically or for some particular purpose in a special context), the 'Socrates' who speaks for Socrates in Plato's earlier dialogues never uses this word and never discusses his method of investigation. He never troubles to say why his way of searching is the way to discover truth or even to say what this way of searching is. He has no name for it. 'Elenchus' and the cognate verb, elenchein (to refute, to examine critically, to censure), he uses to describe, no to baptize, what he does".
} 
chocá-las, quando for necessário, a esta tese $p$; o interlocutor aceita a verdade das premissas extras, $q$ e $r$; porém, $q$ e $r$ implicam não- $p$; o interlocutor encontra-se em dificuldade, já que assume que $p$ e não- $p$ demonstraram ser verdadeiros.

Os comentadores declaram que o elenchos socrático comprovou que o interlocutor sustentava crenças ou opiniões que não estavam de acordo com o próprio grupo de crenças do interrogado. Laques afirma que Coragem é permanecer firme em seu posto durante a batalha, mas Sócrates demonstra que ao sustentar esta tese ele estaria em conflito com sua outra opinião de que o ato de ser corajoso se estende para outros campos diversos. Podemos assumir com isto que o critério de verdade no elenchos, com base nesta leitura de alguns comentadores, é um coerentismo com base em endoxa. Quanto a este critério, vamos discuti-lo com mais detalhe nas seções 2.5.2 e

\subsection{3.}

Nos Diálogos socráticos ainda podemos fazer uma distinção entre duas espécies de refutações. Um primeiro tipo seria uma refutação mais geral, ou melhor, seria a refutação a que chega toda a investigação. Se temos um X a ser investigado e com isto prosseguimos no esquema sistemático costumeiro do método em questão, nota-se que ao final desta investigação, ou nas conclusões parciais, os resultados encontram-se em um impasse adquirido por conta desta própria investigação. O outro tipo de refutação é menor e está subordinada à mais geral. Estas seriam as refutações realizadas durante o processo investigativo que acabam sendo momentos desta primeira, e é através destas refutações que se chega a esta maior.

Por conta deste caráter refutativo, alguns estudiosos justificam que nenhum outro método senão o elêntico estaria mais de acordo com uma afirmação própria de Sócrates, a saber, sua costumeira negação do conhecimento. Eles assumem tal afirmação porque acreditam que o elenchos e a negação socrática do conhecimento 
formam um todo coerente. Mas isso só é possível se assumirmos que o ponto de vista socrático é uma crítica puramente negativa. O objetivo do elenchos seria a refutação por ela mesma com a finalidade de comprovar ou os ditos do oráculo de delfos, revelando que os homens investigados por Sócrates não sabem as matérias que costumam proferir que sabem, ou para demonstrar as habilidades dos interlocutores em defender suas respectivas teses.

Temos como exemplo disto o segundo argumento do Protágoras. Ele vai pondo questões por silogismo, até chegar à conclusão de que cada contrário só admite um único contrário, com o objetivo de chegar a ver se a Sabedoria e Temperança são uma única e mesma coisa. Este trecho deixa claro que existem refutações menores (cada contrário só admite um único contrário) que proporcionam a refutação maior (Sabedoria e Temperança são uma única e mesma coisa).

\subsubsection{A Proferição Socrática da Falta de Conhecimento}

Existem três problemas na negação socrática do conhecimento: primeiro, a questão do oráculo: se Sócrates reconhecia que outros homens não sabiam as matérias das quais se propunham ter conhecimento, o que garantia que Sócrates sabia que eles não sabiam? Segundo, a prioridade da definição: Sócrates declara, em alguns momentos, ter algum tipo de conhecimento sobre matérias éticas, em outros ele é partidário da prioridade da definição, então ele não pode declarar consistentemente que conhece alguma coisa. Terceiro, se Sócrates declara ter algum tipo de conhecimento que ele chama de "sabedoria humana", ele não pode assumir que tem o conhecimento em seu todo, ou seja, o conhecimento científico, pois se ele tivesse esse conhecimento, ele não precisaria pesquisar sobre os objetos que se propõe a investigar. Pretendemos, com 
base nestes problemas da proferição socrática da falta de conhecimento, determinar o que na verdade ele quer significar com isto, isto é, se realmente ele está sendo verdadeiro ou não em declarar que não tem conhecimento ou se ele não está sendo sincero, sendo possível conciliar a declaração de que tem e, ao mesmo tempo, de que não tem conhecimento.

Para Vlastos, a negação socrática do conhecimento é sincera em certo sentido. Não seria contraditório, para as declarações de Sócrates, afirmações e negações do conhecimento. A solução encontra-se no uso do termo episteme. Segundo Vlastos, Sócrates está lidando com dois tipos de conhecimento, o conhecimento científico e o conhecimento elênctico. Quando Sócrates declara não ter conhecimento, ele está se referindo a este conhecimento científico. Quando ele declara ter alguma espécie de conhecimento, ele está se referindo a este conhecimento elênctico. A diferença entre estes conhecimentos é exatamente o anamárteton, "que não pode errar". Vlastos se serve de uma passagem da República (477e):

Sócrates: Mas pouco antes assentaste em que a ciência e a opinião não eram a mesma coisa (Vlla, men dh. ovigon ge proter on wimologeij mh. to. autro. ei al episthmhn te kai.doxan);

Glaucon: Pois como é que alguém que tenha entendimento havia de indentificar o que é infalível com o que não é? (P w' gar an, ef $h$, to, ge anamarthton tw/mh. amamarthtw|tauton tij noun ecwn tiqeih;);

Sócrates: Muito bem. É evidente que concordamos em que a opinião é diferente da ciência $(k a|w|, h \#$ d'egw, kai, dhlon ofi ef eron episthmhj doxa oimol ogeitai himin).

Vlastos guiará sua exposição valendo-se da questão da infabilidade ou não do conhecimento. Com isto, ele acabou de assumir um posicionamento muito forte, 
defendendo que toda e qualquer coisa, para ser considerada como conhecimento, neste caso conhecimento científico, deve possuir infabilidade. Tal comentador identifica essa infabilidade com a certeza: se uma coisa é infalível, ela é certa. Esta certeza é dada da seguinte forma: "Então, o que ele está sustentando é que nós sabemos que P é verdadeiro somente quando nós possuímos o mais alto grau de certeza concernente à verdade de P”. ${ }^{37}$ Este mais alto grau de certeza é o conhecimento científico.

Entendemos que não exista uma relação tão direta entre a certeza e a infabilidade de uma coisa, uma vez a infabilidade se estende para além do campo que compreende a certeza. Se tomarmos o exemplo apresentado no Mênon (97a-b), o caminho para Larissa, a questão neste exemplo não é um caso de certeza, mas de infabilidade. Se um indivíduo tem o conhecimento parcial, opinião verdadeira, de como se chegar a Larissa e consegue chegar lá, ele alcançaria o mesmo fim se possuísse o conhecimento científico. Com isso, a opinião verdadeira não ficaria devendo nada frente ao conhecimento científico. A questão é que a opinião verdadeira corre o risco de sofrer mudança por persuasão, ela necessita daquilo que lhe falta, que é precisamente uma base fundamentada em razões que legitimam a coisa investigada, o que é próprio da natureza do conhecimento científico. Tal indivíduo não tem a certeza de como chegar a tal lugar. Sabemos que a injustiça é má, é infalível assumir isto, porém, não existe nada que nos dê os fundamentos desse fato, nenhuma certeza. Enquanto opinião verdadeira, a injustiça é má, é um conhecimento infalível. Mas não temos certeza de afirmar que tudo que é injusto seja mau, não temos as bases fundamentadas que garantam que a injustiça é um mal. Precisamos primeiramente responder "o que é a injustiça" para verificarmos se ela é boa ou má, precisamos de um fundamento científico sobre a maldade da injustiça para afirmamos com certeza que ela é um mal.

\footnotetext{
${ }^{37}$ Vlastos (1985).
} 
Como Vlastos afirma, Platão está estabelecendo um critério para distinguir opinião verdadeira de conhecimento, e esse critério é o anamárteton. Nós diríamos que a diferença é dada pela certeza adquirida pela investigação. Em um as bases são firmes, nos localizamos em um solo seguro. Na outra forma, já não temos a segurança total, temos a garantia de que em alguns momentos o fim atingido seja o fim correto. A opinião verdadeira, assim como a episteme, não pode deixar de produzir o resultado esperado. Nesse sentido, pode ser assumido que opinião verdadeira é infalível. Não se trata de assumir que apenas uma é infalível e a outra não, ambas são infalíveis. Mesmo que esteja expresso na República que o critério que diferencia estes tipos de conhecimento é a infabilidade, podemos desconsiderar seu testemunho porque não se trata de um Diálogo socrático. ${ }^{38}$

Segundo a interpretação de Vlastos, para que um indivíduo tenha o conhecimento infalível da verdade de $P$, tal conhecimento depende de uma outra coisa, a saber, a evidência $Q$. Esta evidência é o que garante a certeza da premissa $P$. $P$ por si mesmo não nos confere nenhuma certeza. Tomemos, como $P$, a seguinte premissa: "o triângulo tem três lados". A premissa P implica a seguinte evidência Q: nós somos afetados por uma sensação que nos permite reconhecer que essa figura contém três lados. Mas se considerarmos que $P$ seja o seguinte: "a soma dos ângulos internos de um triângulo resulta em dois ângulos de $90^{\circ}$ ", já não encontramos tal evidência Q. Ela não nos confere essa certeza. Antes de afirmamos como verdadeiro que "a soma dos ângulos internos de um triângulo resulta em dois ângulos de $90^{\circ}$, é necessário, para termos tal certeza, verificar se esta premissa cumpre tal função, é preciso passar pelo exame

\footnotetext{
${ }^{38}$ Esta diferença entre episteme e doxa é dada no livro V da República (477e). Talvez pudéssemos considerar o recurso a este Diálogo do período intermediário, e diríamos de passagem propriamente platônico, se esta passagem estivesse no Livro I, que é reconhecidamente considerado um Diálogo socrático. Utilizamos as considerações encontradas no Mênon por ser um Diálogo que possui ainda alguma influência socrática.
} 
científico. Tomemos, por exemplo, a definição de Coragem dada no Laches. Existem duas definições:

$P($ a) permanecer firme em seu posto;

$P(b)$ fugir de seu posto;

Os dois casos são tipos de Coragem, e cada uma destas duas premissas é oposta a outra. De acordo com Vlastos, para cada $P$ uma evidência $Q$ :

$Q$ (a) é evidente que aquele que permanece firme em seu posto e combate os inimigos sem fugir é corajoso;

A segunda evidência, que corresponde à fuga, já não é tão clara. Nossa experiência comprova o contrário, aquele que foge é sempre considerado como covarde. Mas Sócrates dá as razões para isso.

$Q$ (b) Os citas e os cavalos de Enéias combatem tanto perseguindo quanto fugindo.

Para $Q($ b), Laques objeta afirmando uma evidência contrária:

$Q($ a)' os hoplitas combatem como te digo.

E Sócrates dá sua réplica: 
$Q($ b)’ com exceção dos hoplitas lacedemônios na batalha de Platéia.

Como afirmamos logo acima, a premissa $P(\mathrm{a})$ é contrária à premissa $P(\mathrm{~b})$, assim como as evidências $Q(a)$ e $Q(a)^{\prime}$, correspondentes à premissa $P(a)$, são contrárias às evidências $Q(\mathrm{~b})$ e $Q(\mathrm{~b})^{\prime}$, que são correspondentes às premissas $P(\mathrm{~b})$ e $P(\mathrm{~b})^{\prime}$. Trata-se de premissas e evidências contrárias que ocupam o lugar de casos de atos e evidências corajosos. Para um mesmo objeto temos duas premissas e duas evidências contrárias, a definição de Coragem comporta em si tais qualidades contrárias. Ora, como conciliar duas hipóteses "P" e as duas evidências "Q" contrárias com a própria definição de Coragem? As evidências apenas nos dão o conhecimento das coisas que aparecem de forma imediata. Além das evidências temos atos, os acontecimentos, as experiências etc., que acontecem em tempos e momentos diversos. A observação destes nos permite tirar conclusões. Ver um indivíduo permanecer firme em seu posto na batalha não nos confere nenhum conhecimento. Mas se sempre vemos em várias circunstâncias e em vários momentos os mais audaciosos permanecendo em seus postos de forma constante, disto já podemos fazer inferências. Podemos, por exemplo, chegar à conclusão que a audácia é idêntica à Coragem. Porém, nesse momento não podemos dizer com segurança que temos o conhecimento científico de Coragem, o que temos é uma opinião verdadeira.

Acreditamos que Sócrates esteja se referindo a duas formas distintas de conhecimento. Um destes conhecimentos está fundado na nossa experiência, mas sem base científica, o que chamaremos de doxa verdadeira, enquanto o outro está fundamentado e justificado pela investigação, o que chamaremos de conhecimento científico. 


\subsubsection{Problemas acerca do Critério de Verdade na Investigação Socrá tica}

A negação socrática do conhecimento está intimamente relacionada com sua busca por definições. Como foi demonstrado que ele buscava definições reais, podemos concluir que o que ele procurava era o conhecimento científico. Se ele procurava o conhecimento científico, é porque ele não possuía este tipo de conhecimento. Porém, Sócrates, assim como todo e qualquer indivíduo, possui alguma espécie de conhecimento, que não é o científico, o que Irwin nomeou de "pré-concepções", que Vlastos nomeou de conhecimento elênctico, e que iremos nomear de opinião verdadeira, para estarmos de acordo com os termos de tal época e com as conclusões da seçãoanterior. Então, Sócrates nega ter conhecimento científico e afirma ter opiniões verdadeiras.

O elenchos cumpriria a função de demonstrar, ou simplesmente mostrar ao interlocutor, que a tese que ele suscita ou defende não está de acordo com suas crenças pessoais. Por exemplo, Irwin declara que "no Laches, Laques inicia afirmando que coragem é permanecer firme na batalha, mas as questões de Sócrates mostram a ele que esta afirmação conflita com sua opinião de que se pode mostrar coragem em outras formas". ${ }^{39}$ Sócrates, como todos nós sabemos, busca verdades, e sua busca era por verdades morais. Não poderia ser pensado que seu objetivo era apenas tornar consciente aos seus companheiros que eles sustentavam opiniões conflitantes.

Irwin sugere que Laques poderia manter sua definição, e para isso ele deveria remover o que não poderia pertencer a ela, no caso, que nem sempre precisamos

\footnotetext{
${ }^{39}$ Irwin (1995): "in the Laches Laches begins by asserting that bravery is standing firm in battle, but Socrates' questions show him that this assertion conflicts with his belief that one can display bravery in other ways", p.18.
} 
permanecer firmes para sermos corajosos. ${ }^{40}$ Irwin realmente parece estar completamente certo, porém, não interessa para a definição que visa o que existe de comum o que não pertence à esfera da coisa investigada. Assim, se permanecer firme não basta, já que nem sempre permanecendo firme se tem Coragem, mas apenas em alguns momentos, temos portanto uma parte da Coragem. Se a fuga é uma forma de Coragem, porém nem toda fuga, temos uma outra parte. Desta forma, todas as inúmeras formas de Coragem deveriam compor a definição de Coragem. Se isto fosse possível, a definição seria algo do tipo: Coragem é permanecer firme, porém nem toda firmeza é Coragem, além disso, alguns tipos de fuga também são Coragem, mas nem toda, assim como a expectação dos males futuros específicos, a audácia acompanhada de conhecimento e assim por diante. O que acontece é que em todas essas partes temos algo em comum entre elas, existe uma característica própria de cada parte que as fazem ser consideradas corajosas. É exatamente este caráter distintivo que é procurado por Sócrates.

Uma característica peculiar do elenchos socrático é o costumeiro pedido de Sócrates para que seus interlocutores expressem suas opiniões pessoais. Se o exame elênctico tem por finalidade tornar evidente os conflitos internos do grupo de opiniões do interlocutor, justifica-se o pedido de Sócrates exatamente porque é o interlocutor que está sendo examinado.

Logo, o critério de verdade admitido por parte dos comentadores, entre eles Irwin e Vlastos, apresenta-se da seguinte forma: dada uma tese A, dela se segue conseqüências Q e R; se o sujeito admitir opiniões X e Z, e Q e R estão em contradição com X e Z, o interlocutor deve abandonar uma das duas opiniões. O critério é o de

\footnotetext{
${ }^{40}$ Irwin (1995): "He could resolve the conflict created by his initial attempted definition of bravery if he retained the definition and withdrew his admission that bravery does not always us require us to stand firm", p. 19.
} 
tornar coerentes as opiniões sustentadas pelos interlocutores, ou melhor, o critério é um coerentismo com base em endoxa.

Se Protágoras admitisse a tese de que Coragem é idêntica à audácia, seguiria um grupo de conseqüências:

Os corajosos são audaciosos;

A Coragem é uma coisa bela;

Os poceiros, os cavaleiros, os que combatem em peltastas etc., por terem o conhecimento, são audaciosos;

Mas se ele também aceitasse a opinião:

Existem homens ignorantes e que são audaciosos em diversas circunstâncias, logo, corajosos.

As conseqüências de sua tese entrariam em conflito com sua opinião, pois a Coragem ou é audácia acompanhada de conhecimento ou a audácia acompanhada de ignorância. Mas como foi possível chegar aos resultados que chegamos? Para solucionar este problema, pretendemos admitir outro critério de verdade no elenchos, pois o coerentismo com base em endoxa, comumente aceito, limita-se ao interlocutor e suas opiniões. Faremos a crítica a este tipo de critério e apresentaremos um tipo mais defensável, o qual atende, principalmente, à seguinte característica de que "é possível identificar X sem dar sua essência, fazendo uso de outros elementos da realidade e sua relação com X". ${ }^{41}$

\footnotetext{
${ }^{41}$ Robinson (1953): "It is possible to identify X without giving its essence, by making use of
} others elements of reality and their relation to X", p. 54. 


\subsubsection{Contra o coerentismo com base em endoxa}

Vlastos sugere uma descrição mais defensável do elenchos contra as posições sustentadas por Hall e Robinson. ${ }^{42}$ Frente a esses estudiosos, ele se posiciona da seguinte forma:

"O elenchos socrático é uma pesquisa por verdade moral através de argumentação adversária em que uma tese é debatida somente se afirmada como a própria crença do interlocutor, que é considerada como refutada, se e somente se, a negação é deduzida de suas próprias crenças". 43

É claro que a pesquisa elênctica não busca qualquer verdade, Vlastos está certo, e, em se tratando dos primeiros Diálogos, essa pesquisa está bem direcionada, pois ela busca a verdade moral ("Socratic elenchus is a search for moral truth"). Essa investigação feita por Sócrates visa a retirada dessa verdade moral de seus interlocutores. Isso explica o fato de Sócrates sempre pedir para que seus adversários respondam com base em suas próprias crenças, já que é delas que a tese é retirada. As refutações socráticas forçam os interlocutores a encontrarem, valendo-se de si mesmos, o objeto da pesquisa. Se o objeto da pesquisa é a Coragem, quem encontrará o que é a Coragem é Laques, através do exame de perguntas e respostas do método aplicado.

${ }^{42}$ Hall (1967): "the Socratic elenchus was perhaps a refined form of the Zenonian paradoxes [1], a prolonged cross-examination which refutes the opponent's original thesis by getting him to draw from it [2], by means of a series of questions and answers, a consequence that contradicts it [3]”, p. 386. Para cada um destes itens 1, 2, 3, Vlastos tem uma objeção, mas, especialmente, o item 3 é identificado com a seguinte declaração de Robinson (1941): "he habitually thought and wrote as if all elenchus consists em reducing the thesis to a self-contradiction”, p. 28.

43 Vlastos (1983), p. 39: "Socratic elenchus is a search for moral truth by adversary argument in which a thesis is debated only if asserted as the answerer's own belief, which is regarded as refuted if and only if the negation of his thesis is deduced from his own belifs". 
Neste caso, a premissa que refuta a tese não é retirada da própria tese nem do interlocutor, quem faz isso é Sócrates. Porém, é do interlocutor que a tese é retirada e quando essa não é consistente, é refutada, e no lugar desta uma outra é posta, bem mais determinada, pelo interlocutor, com a ajuda de Sócrates. Este é um dos motivos do pedido de Sócrates para que seus interlocutores respondam com base em suas próprias crenças. Mas ainda é um motivo muito geral, se for tomado com o objetivo de fazer os interlocutores encontrarem por si mesmo o objeto da pesquisa, desta forma ficando concorde com a proferição socrática da falta de conhecimento.

O caminho que pecorreremos para responder esta questão terá de passar por uma questão problemática na exposição de Vlastos. Nesta sua declaração que tomou uma posição mais defensível, vemos Sócrates sempre exigindo que seus interlocutores dêem suas respostas baseadas em suas próprias opiniões. O problema é quando ele assume a seguinte posição, tal como se encontra em sua afirmação:

1) O elenchos socrático é uma pesquisa por verdade moral através de argumentação adversária em que uma tese é debatida somente se [only if] afirmada como a própria crença do interlocutor;

2) É considerada como refutada, se e somente se [if and only if], a negação é deduzida de suas próprias crenças (itálicos nossos).

As afirmações "somente se", only if, e "se e somente se", if and only if, são fortes. O que elas revelam é que toda a refutação socrática só estaria baseada nas idéias dos seus interlocutores, ou seja, em suas opiniões pessoais. Os primeiros pontos para ir de encontro a essas afirmações, como testemunhos contrários, são os trechos do Laches, do Carmides e do Eutífron que trataremos a seguir.

No Laches (194c), depois da tentativa fracassada de Laques de definir a virtude pesquisada, Nícias se posiciona na investigação: “parece-me, pois, que há pouco tempo, 
Sócrates, não foi corretamente definida a Coragem. Com efeito, tu não expuseste a tão brilhante observação que já presenciei fazer”. Algo na investigação precedente de Laques e Sócrates não satisfez as expectativas de Nícias. Este observa que algo que deveria ser considerado está faltando na investigação. Como ele mesmo fala, isso que falta é uma consideração já feita por Sócrates. Admirado, ele deseja saber qual seria esta afirmação que ele mesmo já havia feito. Neste momento, vemos Nícias expondo uma opinião que não é sua, e sim de Sócrates:

Nicias: inúmeras vezes te ouvi dizer que cada um de nós é bom nessas coisas em que se é sábio, e mal nessas coisas em que se é ignorante. (P ollakij akhkoa, sou legontoj ofi tauta agagoj ekastoj himw aper sof oj, a]de. a maghj, tautta de.kakoj.);

Sócrates: Por Zeus! Certamente, dizes a verdade, Nícias. (VA I h qh/ment oi nh. D i a l egei j, w =N ikia.);

Nícias: Por conseguinte! Se for verdade que o corajoso é bom, é evidente que é sábio. (oukouh eiper o'andreibj agagoj, dhlon ofi sof oj estin.);

Sócrates: Comprendeste, Laques? (: H kous a j, w $=L$ a c h j ;);

Laques: Sim, mas não apreendo completamente o que ele diz. (: E gw ge, kai . ouv sf odra ge manganw o]l egei.);

Sócrates: Eu creio ter apreendido: ele me parece afirmar que a Coragem é uma forma de Sabedoria. (A II, egw, dokw/ manqanein, kai, moi dokei/anhr sof ian tina.thn amdreian I egein.).

Ao final desse debate vemos Sócrates assumindo que a definição de Nícias, que está baseada nas opiniões socráticas, é que a Coragem é um tipo de saber. Está sendo discutida uma tese socrática que foi posta por Nícias. Não o vemos expondo suas opiniões pessoais. A investigação parte do fato de que cada um é sábio naquilo em que é 
bom. Depois disso, Nícias conclui que o homem corajoso é bom, logo ele é também sábio. Em seguida, Sócrates conclui afirmando que a Coragem é um tipo de Sabedoria. Não problematizaríamos isso se tal idéia tivesse surgido unicamente de Nícias. Na verdade, ela é totalmente socrática, e se torna um problema por isso. Está mais do que claro que nesse momento da investigação a tese não está sendo debatida somente se esta for afirmada como a própria crença do adversário de Sócrates, e neste trecho deste Diálogo o adversário é Nícias. Não se trata de uma passagem simples, ela é o divisor de águas da investigação no Laches, e poderíamos dizer que é o trecho mais importante da pesquisa porque direciona e põe as principais questões do Diálogo, entre as quais a tese da Unidade das Virtudes.

No Eutífron (11e), Sócrates propõe uma saída para personagem homônima que se encontra em dificuldade. A proposta de Sócrates é a seguinte: “veja, pois, se não te parece necessário que todo pio seja justo" (i de.gar ei vouk a nankaion soi dokei/dikaion ei al pan to. oß ion). Aqui não temos outra coisa que Eutífron adotando uma posição que não é a dele. Ele concorda com a proposta de Sócrates e a investigação prossegue a partir dessa idéia. A pesquisa agora gira em torno de uma máxima dada por Sócrates, a Piedade é uma parte da Justiça. Esta não é uma afirmação de Eutífron, não é uma tese que foi retirada dele, ela não surge deste interlocutor, não pode e nem deve ser considerada como uma opinião própria dele. É Sócrates que a põe, e quando ele a põe não o faz com o objetivo de refutar nenhuma tese anterior de seu interlocutor, que é, como sabemos, uma das funções de Sócrates. Dorion compartilha dessa mesma opinião: "Sócrates toma os comandos do diálogo e propõe por si próprio uma nova pista de pesquisa que conduzirá, brevemente, à terceira definição. $\mathrm{Na}$ opinião de vários comentadores, esta nova definição, cuja formulação compete de fato a Sócrates e que será finalmente deixada de lado em vez de ser refutada, propriamente falando, 
compreende os principais elementos da concepção socrática de piedade". ${ }^{44}$ Algo que deve ser tornado claro aqui é que não estamos assumindo que Sócrates já possui o conhecimento do que ele investiga. Quando afirmamos que o que ele expôs é dele, não significa que ele já tenha a resposta ou a definição do objeto investigado. O que pretendemos expor é que essa tese não foi dada pelo interlocutor de Sócrates, ela foi retirada de nosso famoso interrogador. Realmente, ele não pode responsabilizar-se pela tese apresentada. A única coisa que ele pode fazer é tratá-la como uma possibilidade, pois a tese precisa ser verificada. Ela é posta na pesquisa para se julgar se ela (a premissa dada) cumpre o papel da própria coisa investigada, já que a definição real de X, como discutimos, dá a essência de X. Aliás, o que ele faz em toda investigação é tratar todas as premissas dadas por seus interlocutores como hipóteses que necessitam ser investigadas e vemos, agora, que estão incluídas as que ele mesmo suscita, assim como aquelas de um outro qualquer, que surge como auxílio na investigação. É o que Dorion fala em sua Introdução ao Eutífron: “enfim, não seria exato afirmar que Sócrates responsabiliza-se pela terceira definição, pois ele a apresenta como hipótese ("se a piedade é uma parte da justiça...” 12d) e não como uma afirmação franca e definitiva", ${ }^{45}$ assim como nenhuma outra será definitiva até que se encontre aquela capaz de tornar-se como tal. O trecho a seguir prossegue com essa idéia de que a relação entre Piedade e Justiça é a mesma entre parte e todo:

\footnotetext{
${ }^{44}$ Dorion, 1997: "Socrate prends les commandes du dialogue et propose de son prope chef une nouvelle piste de recherche qui conduira, sous peu, à la troisième définition. De l'avis de plusieurs commentateurs, cette nouvelle définition, dont la formulation revient en fait à Socrate et qui sera finalement laissée en plan plutôt que réfuté à proprement parler, comprend les principaux éléments de la conception socratique de la piété", nota de tradução 123, p.312.

${ }^{45}$ Dorion (1997), Euthyphron, Introduction: “enfin, il ne serait pas exact d'afirmer que Socrate endosse la troisième définition, car il la présent comme hypotése ( «si la piété est une partie de la justice... »12d) et non comme une affirmation franche et définitive" p. 228.
} 
Sócrates: Então, por acaso, todo justo é pio? Ou por uma parte todo pio é justo, por outra parte todo justo não é pio, mas parte dele é pio, outra parte outra coisa? (tAr' ou\# kai, pah to. dikaion okion; h. to. men opion pah dikaion, to.de. dikaion ouvpah opion, avla.to. men autou/opion, to.de, ti kai.allo;)

Eutífron: Não acompanho, Sócrates, o que dizes. (o u e epomai, w = $S$ wkratej, toijl legomenoij.)

Sócrates prossegue a investigação, desta vez valendo-se de uma máxima posta por ele mesmo, não vemos ela ser retirada de seu interlocutor. A tese a ser examinada é a Piedade como parte da Justiça. Nesse momento não vemos Eutífron retirando essa verdade de si mesmo, nem sequer essa premissa é uma refutação socrática às teses apresentadas por seu adversário. Neste caso, vemos novamente que não é necessário, para o início da investigação, que o interlocutor deva somente responder com base em suas próprias crenças. Nem esta tese que foi apresentada por Sócrates é refutada se e somente se for uma crença própria do interlocutor. Notamos também que essa passagem tem grande importância em toda a investigação. Ela também aparece em um momento crucial da pesquisa, onde está diretamente relacionada a uma grande questão dos Diálogos socráticos - mais uma vez observamos que ela está ligada à tese da Unidade das Virtudes. Além disso, essa passagem é um grande salto em toda a pesquisa em relação ao seu início. Após essa última fala de Eutífron, Sócrates tenta dar exemplos de como deve ser pensada a relação entre a Piedade e a Justiça, utilizando-se da relação entre Medo e Respeito (12b) e da relação entre Número e suas partes, o Ímpar e o Par (12d). Como Eutífron declaradamente fala que não chegou a alcançar o que Sócrates propôs, seu interrogador tenta demonstrar-lhe recorrendo a essas relações que acabamos de falar. É assim que Sócrates se expressa neste referido Diálogo: "na verdade, tendo 
dito, no caso precedente, tal coisa, te pergunto: por acaso, onde está o justo, aí está o pio? Ou, por uma parte, onde está o pio, aí está o justo, ou, por outra, onde está o justo não está, absolutamente, o pio, já que o pio é uma parte do justo?" (t o, t o i out on t oi nun kai. ekei/lêgwn hrwt.wnl aka iha dikaion enqa kai. ofion; h. iha men opion enga kai. dikaion, iha dedikaion ouvpantacou/okionl morion gar tou/dikaiou to. okion; 12c-d).

Eutífron conclui: "não, mas desse modo. Parece-me, pois, que falas corretamente" (ouk, abl' oufw. fainh|gar moi orgw' l egein). A afirmação de Sócrates, "a Piedade é uma parte da Justiça", não é assumida fracamente, ele é bem incisivo, isto é, ele não diz como algo que poderia ser, mas como algo que realmente é: a Piedade é uma parte da Justiça. Não nos parece relevante nesse momento considerar se Sócrates tem o conhecimento ou não do que ele expõe. O que deve ser levado em conta é que é ele quem expõe e não seu interlocutor.

Outro testemunho, neste mesmo sentido, é encontrado no Carmides (162e). Carmides teve todas as oportunidades de tentar definir, com base em suas próprias crenças, o que é a Temperança. Contudo, suas teses não foram suficientemente satisfatórias como uma resposta à pergunta “o que é a Temperança?”. Vendo-se em dificuldade, Carmides recorre a uma tese que não é sua, e Sócrates imediatamente reconhece que tal tese não lhe pertence. Sócrates, tomando conhecimento da falta de experiência de seu interlocutor, pede a Crítias que tome lugar na pesquisa, o que assume para si tanto o lugar de Carmides quanto a tese que este último expôs:

Sócrates: mas, excelente Crítias, eu disse, não há nada de espantoso, certamente, nisto; já que este garoto, por ser tão jovem, não compreende estas coisas. Mas tu, provavelmente, ao que parece, sabe por causa de tua idade e estudos. Se, então, partilhas que isso seja Temperança, deste modo, afirma e aceita este raciocínio. Para mim é muitas vezes mais 
agradável investigar contigo se o que foi expresso é verdadeiro ou não (akl', w=bel tiste, ef hn egw, Kritia, touton men ouden qaumaston agnoeih thlikouton ontal se.de, pou eikoj eidenai kai.hlikiaj eheka kai. epimel eiaj. eivou sugcwreil tout, ei ai swfrosunhn oper outosi. I egei kai. paradech|ton logon, egwge pol u. Van hllion meta. sou/skopoimhn eit' alhaej eite mh.to. lecgen)

Crítias: "mas certamente concordo, disse, e aceito". (a hl a, panu sugcwrwb ef h, kai. paradecoma i)

No Carmides está bem claro que Crítias não só assume o lugar de Carmides, nesse sentido passando a exercer a função de interrogado, mas, além disso, ele toma para si a tese defendida por Carmides. Isso já é o suficiente para irmos contra a tese apresentada por Vlastos. Mas não só isso. Neste Diálogo, a tese que Carmides expõe também não é dele mesmo, o que está declaradamente assumido na seguinte passagem: "Neste instante, pois, me lembrei - uma coisa que já ouvi dizer - que Temperança seria fazer as coisas que lhe são próprias. Considere, então, se isto te parece ter sido dito corretamente" (arti gar anemnhsghn - o] hah tou hkousa legontoj - ofi swfrosunh van eih to.ta. eàutou/prattein. skopei oun tout.o eivorgwl soi dokei/l egein o'l egwn, 161b). Esta sequiência é bem interessante pois, primeiro, Carmides relembra uma tese que ele ouviu de outrem e é com base nela que ele deseja dar continuidade à investigação; segundo, Carmides cede seu lugar na pesquisa para Crítias que a recomeça valendo-se dessa tese que foi sugerida. O que acontece é que nem Carmides, nem Crítias, nem Sócrates estão retirando de si mesmos esta tese. A pesquisa recomeça e prossegue valendo-se não somente das opiniões próprias dos interlocutores, mas ela agora é dirigida por uma tese de um outro que não está fazendo parte na pesquisa. 
Tais passagens destes Diálogos nos revelam que esse posicionamento de Vlastos peca por seu caráter genérico. Mesmo que freqüentemente Sócrates solicite que seus interlocutores tomem parte na pesquisa com base em suas próprias crenças, não podemos tomar como regra geral que o método elênctico somente considera aquelas respostas baseadas nas opiniões de seus adversários. Pelo menos três dos primeiros Diálogos de Platão, o Laches, o Carmides e o Eutífron, testemunham contra essa idéia de Vlastos. Isso já é o suficiente para desconsiderar esse somente empregado por ele. Vemos que não é somente valendo-se das opiniões pessoais de seus interlocutores, mas, acima de tudo, é um também.

Se for do desejo do interlocutor expor uma tese baseada em suas opiniões pessoais, esta será avaliada por Sócrates através do método elênctico. Porém, se for desejo deste expor uma tese que não é sua, essa também será avaliada por Sócrates por meio de seu método costumeiro, o elênctico. Não é somente uma ou outra, pode ser tanto uma como a outra ou ambas opiniões, sejam elas de um interlocutor, sejam de Sócrates, sejam de um terceiro ou outra coisa qualquer, todas, sem excessão, passarão pelo crivo da análise, da refutação, e mais do que tudo, da verdade. Valendo-se desta nossa conclusão, podemos dizer com acerto que, quanto às opiniões pessoais, os interlocutores, na investigação, não precisam se comprometer com estas. Mas o critério com base no coerentismo permanece, já que esta tese inicial pode conflitar com os outros grupos de opiniões que os interlocutores sustentam.

Queremos, também, ressaltar um outro fato, que aparenta ser menos importante, e que vai de encontro a essa mesma afirmação de Vlastos. Nosso objetivo tem apenas por finalidade ressaltar que não existe uma opinião totalmente alheia à cultura de um povo. Qualquer um dos interlocutores, para poder identificar os atos em que se encontra o objeto de pesquisa, terá que fazer isso com base em sua experiência 
própria, com base no que ele mesmo aprendeu e viu. $\mathrm{O}$ interlocutor responde com base nos conhecimentos anteriores que este já possui. Um Diálogo socrático nos diz isso. No Carmides, Sócrates fala: "Bem, pelo menos crês, disse, uma vez que sabes falar grego, dizer sem dúvida como isto mesmo te aparece?" ( oukouh tout. 0 , ge, ef hn, o] oi ei, epeidhper el Ihnizein epistasai, kvan eipoij dhpou autro, ofi soi fainetai; 159a). A referência aqui não diz respeito ao ato de falar grego, mas a todas as influências, idéias, opiniões que Carmides adquiriu ao longo de sua vida, as quais interferirão na sua exposição. Portanto, Carmides deve saber como responder o que é a Temperança, já que ele aprendeu isso entre os gregos. Existe uma base para as respostas à pergunta socrática, elas não surgem do nada. Carmides pode exprimir uma tese que não é sua, uma tese que ele aprendeu com outros ou que sua experiência, na cultura grega, comprovou. Ora, como poderia Carmides, ou qualquer outro adversário de Sócrates, identificar determinados atos como temperantes, ou qualquer outro ato virtuoso, se ele mesmo não tivesse antes a experiência que lhe demonstrou, ou, quem sabe, um outro companhe iro que o tivesse ensinado, que tal ato identificado como temperante pode ser nomeado como tal? As respostas dos interlocutores carregam toda uma carga cultural, toda uma gama de experiências, e isso é inevitável.

Para melhor explicar o que acabamos de dizer, nomearemos três tipos de opiniões. Uma chamaremos de opinião subjetiva, que será aquela que pertence ao íntimo do ser humano em contraste com os dados da experiência geral. A outra chamaremos de opinião particular, já que este tipo de opinião se caracteriza por ser um tipo de opinião geral que é comum a cada indivíduo que a possui. A terceira chamaremos de opinião geral ou universal, já que é aquela que é comum a toda opinião particular. Esta terceira se identificaria com o conjunto dos valores, dos costumes, das regras de conduta, das crenças etc., de um povo. 
Tomemos primeiramente a opinião particular. Como dissemos há pouco tempo, a opinião particular é aquela que se caracteriza por ser a menor parcela da visão geral de um povo, ou melhor, a opinião particular é a opinião de um indivíduo que é, portanto, a representação dessa opinião geral. O indivíduo seria, propriamente, essa menor parcela. Essa opinião é introjetada no indivíduo por todo o meio que o envolve através da formação que este recebe, seja pelo auxílio da educação, da coação exercida pela sociedade, da imitação ou qualquer outro meio que o valha. Logo, temos que essas opiniões particulares fazem parte de um todo, elas estão contidas nele. Esse todo é exatamente a opinião geral, ou melhor, universal. Desta forma, o que todas essas opiniões particulares tem em comum é essa opinião geral, universal. Portanto, essa opinião particular tem por essência aquela que lhe é universal. É precisamente esta condição que permite que esta opinião particular exista, ou seja, é por fazer parte desse universal que esse particular pode ser considerado como particular. Se isto não fosse possível, todos esses particulares seriam unidades orgânicas incomunicáveis, tornando impraticável com isso a menor possibilidade de se estabelecer uma relação entre elas mesmas, ou seja, a impossibilidade mesma do próprio diálogo. No entanto, elas não estão isoladas. O que entremeia essa relação entre elas é exatamente essa opinião geral, universal. É ela a responsável por tal relação e que permite a existência de uma comunicação entre as opiniões particulares.

Com a ajuda de algumas passagens do Eutífron, podemos notar isso que acabamos de tratar. Eutífron é um sacerdote ateniense versado nos assuntos divinos. Resulta disso que ele tem o conhecimento esperado para dar a resposta satisfatória à pergunta socrática, “o que é a Piedade?", já que Piedade é uma matéria que compõe tais coisas divinas. É de se esperar que Eutífron tenha o conhecimento desta virtude. 
Sócrates, valendo-se do fato de ter Eutífron como um conhecido, deseja que este lhe demonstre o que é esse objeto que será investigado:

Sócrates: Tu, então, por Zeus, Eutífron! Tu crês, acerca das coisas divinas, ter o conhecimento delas com exatidão, de modo que tens da mesma forma das coisas pias e ímpias. Por conseguinte, se isto assim se passa como tu falas, tu não temes processar teu pai de maneira a cometer, por acaso, algum ato ímpio? (su. de. dh, proj Dioj, w=E uquf rwn, outosi. akribwl oiei epistasqai peri.twh qeiwn oph ecei, kai, twh osimn te kai. anosiwn, wṣte toutwn oufw pracgentwn wj su. I egeij, ouvf obhl dikazomenoj tw/patri. opwj mh. au=su. amosion pragma tugcanh] prattwn;)

Eutífron: Eu em nada teria vantagem, Sócrates, e Eutífron não se distinguiria em nada da multidão de homens, se não conhecesse com exatidão todos estes tipos de coisas. (ouden gar an mou of el oj eih, $w=$ Swkratej, oude, tw| Van diaf eroi Euquf rwn twh poll wh angrwpwn, ei vmh.ta.toiauta panta akribwi eideihn, 4e-5a)

Existe uma espécie de conhecimento que Eutífron possui. Mas onde foi que ele o adquiriu? Nesta passagem tal interlocutor é bem enfático. Diz ele ter o conhecimento exato destas coisas. Mesmo que este tente ao máximo expor uma opinião completamente pessoal, ele não conseguiria devido à influência que lhe foi exercida através desta opinião geral. Ele é um sacertode e irá expor o conhecimento adquirido por um sacerdote. Bem à frente, Sócrates sugere uma relação entre a Piedade e a Justiça. A investigação é influenciada por conhecimentos que não são exclusivos dos interlocutores. Vemos que sua opinião particular está sendo influenciada por uma universal. Ao final deste Diálogo, depois de Eutífron ter sido refutado em todas as suas 
tentativas, Sócrates persevera em dizer que ele tem tal conhecimento: "é necessário que nós examinemos, novamente, desde o início, o que é o pio, pois, no que me toca, eu não abandonarei, voluntariamente, antes que não a tenha apreendido. Não me despreze, mas concentra-se, com todas as tuas forças, e agora, mais do que nunca, diga-me a verdade. Pois se existe alguém entre os homens que detém este saber, és tu, e é necessário não te deixar partir, como Proteu, antes que tu tenhas falado" (15d). Interpretamos esse fato como uma demonstração de que Eutífron, mesmo depois de falhar em sua empresa, tem de certa forma o conhecimento de tais coisas investigadas. Cremos que Sócrates tem em mente o critério de verdade que ele acredita ser o verdadeiro. Eutífron sabe não só identificar as partes do todo da coisa investigada, como também sabe identificar que determinados atos são pios, que estão ligados obviamente à Piedade, e que também possuem uma relação íntima com a Justiça, já que ele concordou com Sócrates que a Piedade é uma parte da Justiça. Com base nestas informações anteriores, que chamamos de opinião verdadeira, Eutífron, entrechocando-as, chegará ao objetivo esperado por Sócrates.

Tais passagens do Eutífron não nos satisfazem por completo. Iremos recorrer ao Mênon para falarmos sobre opinião. Ressaltamos que não temos o interesse de procurar demonstrar uma identificação entre a doutrina exposta neste Diálogo com aqueles Diálogos socráticos, mas queremos somente nos valer da idéia que este texto apresenta sobre a noção de doxa verdadeira.

Sócrates: Que te parece, Mênon? Há uma opinião que não seja dele que este menino deu como resposta?

Mênon: Não, mas sim dele.

Sócrates: Dizes a verdade.

Sócrates: Mas estavam nele, essas opiniões; ou não? 
Mênon: Sim, estavam.

Sócrates: Logo, naquele que não sabe [ei doti ], sobre as coisas que por ventura

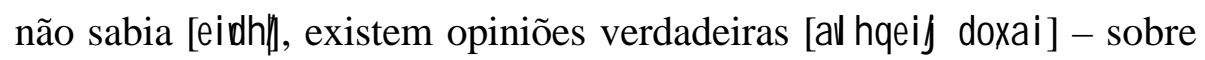
estas coisas que não sabe [0 i ‡e]?

Esta passagem do Mênon é exatamente aquela em que o garoto, que Sócrates utiliza para demonstrar sua doutrina da reminiscência, chega por si mesmo à conclusão da investigação. Sócrates mostra com isso que ele, mesmo sem saber, tinha o conhecimento necessário para chegar a tal ilação. Ora, mas o que são essas opiniões verdadeiras de que fala Sócrates? Que espécie de conhecimento é esse que possui o garoto da casa de Mênon? Continuando na pesquisa do Diálogo, mais à frente Sócrates duvida da capacidade de que muitos homens ilustres têm o conhecimento do que é a virtude e, com isso, a própria incapacidade de repassá-la aos seus decendentes. Isso devido ao fato destes não terem o conhecimento do que é a Virtude. Após assumir essa posição, ele é questionado sobre o fato de que na experiência política grega muitos destes ilustres foram responsáveis pelas mais belas e justas leis. Como Sócrates, depois deste questionamento, se safaria deste impasse? A resposta repousa na noção de opinião verdadeira: "Se não é graças à ciência [ep i sthmh], então, resta que é graças a uma feliz opinião [eudoxi a ]? Servindo-se delas os políticos administram retamente as cidade (...)”, (99b-c). Assim como expusemos acima, estes homens ilustres, o escravo de Mênon e Eutífron possuem um conhecimento sobre as coisas investigadas. É um conhecimento débil, mas nele repousa, de forma encoberta, traços da verdade sobre elas mesmas.

Se pensarmos nessas três opiniões e retirarmos a opinião particular e a geral, teremos, assim, isolado uma única entre estas, aquela que foi nomeada de opinião subjetiva. Tudo o que é puramente do indivíduo, aquilo que pertence unicamente a seu íntimo, é a opinião subjetiva. Ora, mas como seria possível pensar um puro 
subjetivismo? Nossa opinião é que isso em parte é e em parte não é possível. Em teoria, realmente podemos pensar essa opinião puramente subjetiva, porém, no que acontece de fato, na própria realidade, esse subjetivismo apenas aparece confundido, mesclado, misturado a essa opinião particular. Mesmo que o interlocutor se esforce para expressar uma opinião puramente pessoal, ele não poderia escapar à mácula da opinião particular que, por sua vez, carrega em sua essência a universal. Portanto, esse universal permeia todas as opiniões, tanto a particular quanto a subjetiva, já que não existe esse puro subjetivismo, e por ter tal natureza de cobrir toda a realidade, no nosso caso ao que está relacionado às opiniões, ele deve necessariamente ser o mesmo para todas elas.

Podemos até mesmo afirmar que não é do interesse de Sócrates as opiniões subjetivas, já que elas abrem um leque de possibilidades, uma enorme quantidade de acepções para um mesmo objeto. Isto não interessa a Sócrates. Este procedimento deve ser dispensado para possibilitar que o caminho que está sendo traçado seja alcançado sem que os investigadores se desviem de seu objetivo. Logo, esse somente de Vlastos peca por não levar em conta esse aspecto da opinião. Por isso que é permitido ao interlocutor tanto expressar suas opiniões pessoais quanto a de qualquer outro, já que a pesquisa se compromete com a verdade, e as opiniões particulares permitem que, através delas mesmas, essa verdade seja encontrada, exatamente por conterem em si mesmas traços dessa própria verdade.

Interpretamos o significado do pedido de Sócrates de que os interlocutores expressem suas próprias opiniões da seguinte forma: não importa de quem seja a tese que será apresentada, pode ser do próprio interlocutor, de Sócrates ou de um outro qualquer, quando a tese é posta, neste caso pelo inquirido, este deve assumir a responsabilidade de defendê-la. Na pesquisa elênctica existem dois personagens, o que pergunta e o que responde. Este último é quem deve tentar demonstrar que a tese que 
ele mesmo está apresentando tem sua razão de ser, ou seja, ela poderá corresponder plenamente ao que é exigido, ao que é pedido por Sócrates quando este elaborou a pergunta “o que é $X$ ?”. Como a função de respondente é do interlocutor, é ele quem deve defender a tese apresentada, já que é ele mesmo que está presente, como única testemunha.

Mas se estamos indo de encontro a um pedido freqüente de Sócrates, que é o de solicitar a seus interlocutores que respondam com base em suas próprias crenças. Como poderemos encontrar uma solução para esse problema se o próprio texto nos demonstra que muitas pesquisas só puderam ter seu início quando os interlocutores de Sócrates passaram a expressar suas próprias opiniões? É possível contornar esse problema, já que encontramos textos que falam a favor de nossa teoria enquanto outros nos demonstram o contrário? Partiremos para a análise destes Diálogos que nos manifestam o contrário de nossa tese como tentativa de solucionar este problema. Podemos iniciar citando o Protágoras e o Mênon ${ }^{46}$. Neste dado momento, faremos a análise dos trechos dos Diálogos citados logo acima:

No Protágoras, em 331c-d, existe a seguinte passagem:

Protágoras: Não me parece absolutamente, Sócrates, que a coisa seja tão simples para que eu possa pôr-me de acordo contigo de que a santidade seja justa e a Justiça seja santa, e creio ver aí alguma diferença. Mas que importa? - disse ele: - se desejas, admitamos que a Justiça seja santa e a santidade justa. (Ouvpanu moi dokei $b$ ef $h, w=$ Swkratej, oufwj ap̀louh eimai, wste sugcwrhsai thn te dikaiosunhn opion ei ai kai, thn ośiothta dikaion, alla, ti, moi

\footnotetext{
${ }^{46}$ Outros Diálogos que apresentam essa característica são: Apologia 29d-30a; Górgias 500b;
} Criton 49c-d, 49a; República I, 346a. 
dokei/en autw/diaforon ei ai. ahla.ti, touto diaf er ei; ef hl eivgar

boulei, estw himin kai.dikaiosunh op̣ion kai.os̀iothj dikaion.)

Sócrates: Jamais - repliquei-lhe: não é com fórmulas se deseja, se isto te agrada, que peço uma demonstração: é por ti e por mim; se me coloco ante tua pessoa e a minha, é que a melhor maneira, segundo meu parecer, de provar nosso raciocínio, consiste em eliminar deles os se. ( $M$ h, mo i, $h$ \# d'egw» ouden gar deomai to, «eivboul ei » touto kai, «ei; soi dokei » evegcesqai. ahl' eme, te kai. sel to. d' «eme, te kai. se» touto I egw, oirmenoj oufw ton I ogon bel tist, van elvegcesqai, ei; tij to, «ei » affel oi autoul.)

O ponto importante dessa passagem é o trecho em que Sócrates fala que na investigação os se devem ser eliminados, o que revela é que Protágoras deve levar em consideração as suas próprias crenças, sem dar importância a nenhum testemunho extra. Ninguém, além de Protágoras, deve tentar responder ao que seu interrogador solicita. Nenhuma outra pessoa deve cumprir essa função na pesquisa, nem pessoalmente nem de forma indireta, neste caso por intermédio do interlocutor. Protágoras assume sua posição, é aquele que responde, não assumindo nenhuma outra posição que não seja a dele mesmo, de interlocutor, e isso inclui não utilizar-se das opiniões de Sócrates dos outros, pois os se te agrada ou se te apraz devem ser eliminados. Protágoras não deve basear sua pesquisa naquilo que será melhor para Sócrates ou para qualquer um outro, ou no que agrada a Sócrates ou deixe de agradar, pois se fizesse isso estaria assumindo as opiniões que Sócrates aceitaria ou deixaria de aceitar. Ele deve assumir aquilo que ele expressa como seu, ou melhor, ele deve assumir aquilo que é melhor para a investigação. De acordo com o coerentismo com base em endoxa, ele deve fazer isso para expor suas opiniões com o fim de verificar se elas entram em conflito com suas 
reais opiniões. Ao fazer o que deve ser tido como melhor, expondo suas próprias crenças, ele entraria em um momento do método elênctico. Esta explicação demonstra o oposto do que defendemos logo acima.

No Mênon, em 71c-d, a passagem nos mostra:

Sócrates: não tenho lá muito boa memória, Mênon, de modo que não posso dizer no presente como me pareceu naquela ocasião. Mas talvez ele, Górgias, saiba, e tu saibas o que ele dizia. Recorda-me então as coisas que ele dizia. Ou, se queres, fala por ti mesmo. Pois sem dúvida tens as mesmas opiniões que ele. (0 uvpanu ei $m i$. $m n h m w n, w=M$ enwn, w $k$ te ouk ecw eipein en tw/ paronti pwi moi tote edoxen. abl iswj ekeihoj elegel anamnhson ou me pwi el egen. eivde. boulei, autoj eipel dokei/gar dhpou soi.aper ekeinw/)

Mênon: tenho sim. (: E moige.)

Sócrates: deixemos pois Górgias em paz, já que afinal está ausente. Mas tu mesmo, Mênon, pelos deuses! Que coisa afirmas ser a virtude? Dize, e não te faças rogar, para que um felicíssimo engano seja o que eu tenha cometido, se se revelar que tu e Górgias sabeis o que é a virtude, tendo eu dito, ao invés, jamais ter encontrado alguém que soubesse. (vekeihon men toinun ewmen, epeidh. kai. apestinl su.de. autroj, w=proj qewh, Menwn, ti, fhl avethn ei ai ; eifon kai, mh. f qonhshl, iha eutucestaton y eubma ey eusmenoj wavan fanhl su. men eidwj kai. Gorgiaj, egw. de. eirhkwj mhdeni.pwpote eidoti entetuchkenai.)

Como a solicitação socrática de que seus interlocutores dêem suas repostas baseados em suas próprias crenças é considerada como uma característica do método elênctico, tomamos essa passagem emprestada do Mênon, exatamente por esse Diálogo 
conter essa característica que Vlastos ressaltou, própria desse método. Nessa passagem do Mênon, foi pedido à personagem homônima que diga o que é a virtude. Em um primeiro momento é solicitado que ele reproduza o que ela é de acordo com a concepção de Górgias. Duas coisas podemos ressaltar que se oporiam ao que nós expomos acima quanto ao pedido de Sócrates para que seus interlocutores falem por si mesmos. Em primeiro lugar, Sócrates fala, “deixemos pois Górgias em paz, já que afinal está ausente”. Górgias não está participando da discussão, e as opiniões dele não podem ser levadas em consideração, já que ele mesmo, por não estar presente, não teria como defender-se. Como sempre se exige as opiniões pessoais dos interlocutores, as idéias de Górgias não poderiam fazer parte da pesquisa, pois não seria possível verificar se estas opiniões, em Górgias, conflitariam. Este primeiro fato já vai de encontro à nossa hipótese acima. Em segundo lugar, como são as opiniões pessoais que devem ser expressas, Mênon tem que abandonar os ditos de Górgias e deve continuar por si mesmo a investigação, visto que na passagem acima Sócrates diz "fala por ti mesmo" e “deixemos pois Górgias em paz, ła que afinal está ausente. Mas tu mesmo, Mênon, pelos deuses! Que coisa afirmas ser a virtude?” (itálicos nossos). Ele, por si mesmo, deve levar a cabo a pesquisa com base em suas próprias crenças. Assim, novamente seria verificado se as opiniões sustentadas por Mênon são as que ele realmente acredita. São as opiniões, as crenças pessoais, que devem ser empregadas na pesquisa, isto é, ela só terá continuidade se essas opiniões e crenças forem de autoria dos adversários de Sócrates, com o objetivo de atender ao critério de verdade que, comumente é aceito pelos comentadores.

Será que estaríamos em uma dificuldade? Afirmamos acima que não importava para Sócrates se a opinião expressa era de autoria de seus interlocutores ou de um outro qualquer para que a pesquisa se encaminhasse. Para isso, fomos buscar os testemunhos 
dos seguintes Diálogos: Laches, Carmides e Eutífron. Logo em seguida, localizamos em outros Diálogos, com estrutura elênctica, ${ }^{47}$ que a pesquisa só deveria ser encaminhada se os interlocutores expusessem suas próprias crenças. Como sair desse impasse? Para alcançarmos a solução é necessário considerarmos duas coisas:

a) a resposta será dada quando soubermos o que significa esta exposição das próprias crenças dos interlocutores;

ß) quando soubermos qual é o próprio desejo de Sócrates, o que ele quer encontrar na investigação.

O que vem a ser esse pedido de Sócrates que faz com que a exposição só venha a ter seu início quando seus interlocutores expõem suas próprias opiniões? Propomos duas interpretações como solução a essa dificuldade:

S1) o objetivo de Sócrates, unicamente, é o de encontrar a verdade - com isso responderíamos ao item a;

S2) como decorrência da primeira, tentaremos mostrar que o esforço de Sócrates é tentar evitar que várias opiniões sobre um mesmo objeto sejam expostas com essa hipótese estaríamos respondendo ao item $B$.

Mas antes de começar nossa exposição por estes dois pontos que acabamos de tratar, pretendemos analisar as soluções que Vlastos apresenta como a resposta para este mesmo problema:

A) Como primeira solução, Vlastos aposta no fato de que os interlocutores devem ser honestos em sua exposição. Como ele fala, o objetivo de Sócrates, no que diz respeito a esse pedido, é "testar a honestidade na argumentação". 48 Esta afirmação de Vlastos está baseada na prática dos

\footnotetext{
${ }^{47}$ Além do Protágoras e do Mênon, indicamos outras passagens de outros Diálogos, Cf. n. 46.

48 Vlastos (1983): "to test honesty in argument", p. 43-44.
} 
jogos erísticos, pois ele crê que esse pedido de Sócrates tenta evitar que a pesquisa venha a cair nesse jogo discursivo. Estamos de pleno aconcordo com essa leitura de Vlastos. É necessário evitar o torneio erístico e dedicarse unicamente a alcançar a verdade procurada, sem importar-se com a vitória típica desse torneio. Porém, no que diz respeito ao que ele propõe como solução, que é testar a honestidade dos interlocutores, não podemos permanecer de acordo.

B) De acordo com Vlastos, a segunda solução é a seguinte: o ato de Sócrates pedir que os interlocutores exponham suas próprias crenças tem o objetivo de "testar a seriedade de alguém na busca pela verdade". ${ }^{49}$ Ele quer dizer com isso que os interlocutores devem, no momento em que dão as respostas às investidas de Sócrates, não fazer uma falsa figura ao responderem. Mas o mais curioso nessa solução é a conseqüência que decorre dela: quando o interlocutor expõe sua própria crença, assumindo um compromisso com a verdade e sendo franco com sua exposição, ele estaria comprometendo-se com o bem-viver. Isto, de acordo com Vlastos, prenderia sob fortes grilhões a responsabilidade do interlocutor à apresentação de sua tese. A investigação teria um segundo objetivo, a qual não se desliga do primeiro, que é a procura pela verdade, e que culminaria numa mudança na vida dos que participam desta pesquisa. Ela é necessária porque desvia aqueles que participam da investigação da prática da injustiça e de toda sorte de vício, orientando-os em direção ao bem-agir que implica, diretamente, o bem-viver. Vlastos expressa-se da seguinte forma: "Mas se alguém declara, por si mesmo, publicamente, o que acredita, foi

${ }^{49}$ Vlastos (1983): “to test one's seriousness in the pursuit of truth", p.44. 
dado o peso de sua própria vida para a opinião deste. Já que as pessoas consideram suas opiniões mais prescindíveis do que suas vidas, Sócrates deseja essas opiniões para amarrá-las às suas vidas, como uma promessa que o que eles falam é o que eles querem dizer". ${ }^{\mathbf{5 0}}$ Vlastos demonstra com isso que o elenchos tem uma dimensão existencial, exemplo dessa caracteristica existencial peculiar ao elenchos, e ele mesmo utiliza-se dele, encontramos no Laches: "para mim tu pareces não saber que quem é íntimo de Sócrates [pela conversação assim como pelo parentesco] e aproxima-se dele para discutir, inevitavelmente, mesmo que ele, primeiramente, comande a discussão através de um outro objeto, não faz cessar sobre este a condução do discurso; antes se lança sobre o próprio pensamento daquele, em qual modo agora vive e em qual modo, até então, viveu a vida: quando isto se apresenta, o próprio Sócrates, primeiramente, não o deixará ir antes de por a prova essas coisas bem e belamente em todas as suas acepções" (ou; moi dokeil eidenai ofi of van eggutata $S$ wkratouj $h \equiv[$ logw wkper genei] kai.plhsiazh|dial egomenoj, anagkh autw bean ara kai. peri. allou tou proteron arxhtai dialegesqai, mh. pauesqai upo. toutou periagomenon tw/logwb prin <Van> empeshleij to, didonai peri, autoul logon, ohtina tropon nuh te zhl kai. ohtina ton parelhluqota bion bebiwken I epeidan d'empeshb ofi ouvproteron auton afusei swkrathj, prin van basanishl tauta eu= te kai, kalwl apanta, 187e-188a). A interpretação de Vlastos não acrescenta nada de inovador, pois tal leitura

\footnotetext{
${ }^{50}$ Vlastos (1983): "But if one puts oneself on record as saying what one believes, one has given one's opinion the weight of one's life. Since people consider their opinions more expendable than their life, Socrates wants them to tie their opinions to their life as a pledge that what they say is what they mean", p.44.
} 
não diferenciaria a prática socrática de nenhuma outra dentro da experiência grega. É evidente, para todo estudioso da cultura grega, que qualquer um dentro desta experiência teve a pretensão de melhorar a vida de qualquer um outro, tenha sido este pretenso aprimorador da vida de seus concidadãos um sofista, um poeta, um político, ou um retor ou um outro qualquer. Não importa quem seja, todos tinham por pretensão modificar a vida daqueles que os acompanhavam. Esses que tinham tal presunção achavam que estavam fazendo o que era melhor para esses discípulos. Seria de se estranhar que Sócrates não considerasse que poderia melhorar a vida daqueles que o acompanhavam na pesquisa. ${ }^{\mathbf{5 1}}$ Se ele não achasse isso, de que serviria toda essa investigação? Se a solução fosse exclusivamente essa dada por Vlastos, em que Sócrates e seu método se diferenciariam destes outros "pretensos" da cultura grega os quais acabamos de mencionar? Além disso, não concordamos, mais uma vez, que essa solução seja o fato de que Sócrates queria testar a seriedade daqueles que participam da investigação.

C) Com base no que foi tratado por Vlastos como o verdadeiro significado do pedido socrático, o qual ele aponta como as duas soluções A e B acima expostas, ele mesmo apresenta um duplo objetivo para essa solicitação. Ao tentar descobrir como todo ser humano deve viver, mas não só isso, como a passagem do Laches revela também como viveu, vive e deverá viver Sócrates estaria testando seus interlocutores, descobrindo se eles estão vivendo como alguém deve viver. Esta operação foi denominada por Vlastos de “operação dois-em-um” (two-in-one operation). Ele observa que

\footnotetext{
${ }^{51}$ No La. 200e, Sócrates afirma esse objetivo: "isto seria uma coisa incrível, Lisímaco, não querer estar de acordo que alguém torne-se o melhor possível" (kai. gar van deinon ei h, w =L usi mace, tout. 0, ge mh. eqel ein tw|sumproqumeisqai wj bel tistw|genesqai).
} 
o elenchos apresenta um duplo sentido, mas que deve ser considerado como um único: "Sócrates não provê dois tipos de elenchos - um filosófico, procurando pela verdade sobre o bem-viver, e um terapêutico, revelando a própria vida do interlocutor na esperança de levá-lo à verdade. Existe apenas um elenchos e este deve cumprir ambas funções, embora alguém ou um outro se destaque em diferentes partes dele". ${ }^{\mathbf{2}}$ Concordamos em parte com Vlastos, os pontos que ele apresenta têm seu momento de verdade, mas não é o suficiente para dar conta do que é realmente a solicitação socrática, uma exposição com base em suas próprias crenças.

Contra estas soluções apresentadas por Vlastos, apresentamos apenas uma única contra-argumentação: o consenso lógico, um acordo atingido quando logicamente é alcançada a verdade da coisa investigada. Não é Sócrates que convence, mas a razão. Lançaremos mão de um Diálogo que Vlastos freqüentemente faz uso, o Górgias:

Sócrates: (...) não se espante com as coisas que falo, mas a filosofia, minha amada, faça-a parar de falar. Ela diz, caro amigo, neste instante, o que tu ouve de mim, e ela é muito menos volúvel do que são meus outros amados: o filho de Clínias ora diz uma coisa ora diz outra, mas a filosofia sempre diz o mesmo kai. mh. qaumaze of i egw. tauta l egw, akla, thn fil osof ian, ta. ema, paidika, paubon tauta I egousan. I egei gar, w=file etaire, a] nuh emou/akoueij, kai, moi, estin twh eterwn paidikwh pol u. htton emplhktojl o'men gar K I einieioj outoj allote all wn esti.logwn, h'de,filosof ia aci. twh autwh, 482a-b) therapeutic one, searching out the answerer's own life in the hope of bringing him to the truth. There is one elenchus and it must do both jobs, though one or the other will be to the fore in different phases of it". 
Sócrates lhe dá um nome, filosofia. Neste caso, o que ele chama de filosofia é, como expusemos anteriormente, esse ser com força suficiente para fazer com que os investigadores alcancem um consenso. Ela deve estar necessariamente no plano das coisas racionais, no plano da pesquisa lógica.

Com isso, afirmamos que o consenso lógico é o porto seguro da investigação socrática. Vlastos de certa forma afirma o mesmo quando se expressa da seguinte forma: "Em um argumento, seus únicos meios de coação são lógicos. Então, para obrigar Pólos a testemunhar por não-p, Sócrates teria de dar a Pólos uma prova logicamente convincente de que p é falso".53 Temos com isso que o ser racional que interroga (Sócrates) convence, através da refutação, o ser racional que responde (o interlocutor), apenas pela racionalidade, pela lógica, pela filosofia. A investigação é encaminhada por uma inter-racionalidade até seu fim último. São as razões envolvidas que dialogam, não se trata de Sócrates, Laques, Eutífron, Protágoras, a multidão etc. É a razão dos que tomam parte na investigação que reconhece a verdade das coisas investigadas. Há um trecho interessante no Carmides que demonstra exatamente essa tentativa de consenso lógico: "Bem! Eu digo, Critias, que tu, certamente, dirige-se a mim como se eu afirmasse saber sobre as coisas que pergunto, e pudesse estar de acordo contigo somente com o que desejasse. Não é nada disso. Mas procuro sempre contigo, através das coisas propostas, a solução, mas eu não sei. Após ter examinado, por

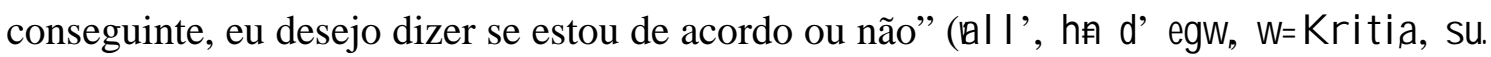
men wj faskontoj emou/ eidenai peri. wa erwtw/prosferh/proj me, kai. ean dh. boul wmai, omologhsontoj soil to. d' our outwj ecei, ahla.zhtw/gar meta. sou/ari.to. protigemenon dia. to. mh. autroj eidenai. skeyamenoj oun eqelw eipeih eite omologw/

${ }^{53}$ Vlastos (1983): "In an argument your only means of compulsion are logical. So to compel Polus to 'witness' for not-p Socrates would have to give Polus a logically compelling proof that $p$ is false", $\mathrm{p}$. 54. 
ei te mh,165b-c). Está bem explícito, depois que as teses foram examinadas não importa de quem elas sejam, ao passarem pelo crivo da verdade é que Sócrates verificará se ele estará de acordo com Crítias ou não. Não se trata de aceitar de bom grado a opinião de seu interlocutor. É necessário analisar a tese que este expôs para, somente assim, ver se o que ele está defendendo é verdadeiro ou não. Se for verdadeiro, existirá um acordo entre as partes, se não, esta tese terá que ser submetida novamente à refutação.

Neste momento da pesquisa, será dado o início do que pretendíamos expor como as soluções para o objetivo de Sócrates. Nossa justificativa parte do segundo item, S2, que suscitamos anteriormente. Nossa sugestão é que o objetivo de Sócrates é evitar que seus interlocutores exponham uma explosão de opiniões, fazendo com que, através dessa solicitação, ele mesmo e seus companheiros não caiam em um turbilhão de idéias e fiquem flutuando nesse turbilhão sem alcançar nenhum objetivo. Com o objetivo de evitar que para uma mesma coisa sejam expostos vários sentidos dos mais diversos e variados, incluindo, além disso, um conjunto de significados que se excluem uns aos outros, Sócrates pede que seus interlocutores exponham suas próprias crenças. Quando se diz várias coisas de um mesmo objeto corre-se o risco de não ser encontrada a verdade sobre esse mesmo, corre-se o risco de que o alvo perca seu foco e que os investigadores se percam do caminho que está sendo traçado. O que sabemos é que a maior parte dos sofistas podiam, para uma mesma coisa, fazer discursos tanto a favor quanto contra, adaptando-os à melhor situação que testemunhasse a favor do que eles pretendiam defender. O Protágoras expõe o que é um sofista, revelando-nos desta forma o que declaramos há pouco. Sócrates os coloca como comerciantes que vendem mercadorias das mais diversas, as quais seriam, em se tratando dos sofistas, as ciências, sem ter conhecimento do bem ou do mal dessas mercadorias que eles comercializam (Prot. 313a-314b). Isso é possível exatamente por eles terem essa capacidade de 
expressar diferentes opiniões tanto a favor quanto contra a respeito de um único objeto, com o objetivo unicamente de "venderem essas mercadorias", no caso o que eles acreditam que são as ciências. A declaração de Ildefonse é fundamental para o que pretendemos expor: "A confusão e a indeterminação na matéria são um dos recursos da sofística - se, por exemplo, uma pessoa tenta se desfazer de um acordo que ela fez, pretendendo, então, que ela não falou em seu próprio nome, sem, para tanto, ter advertido que este era o caso. Donde a matéria dialética, que repousa, etapa após etapa, sobre alguns pontos, para os quais, verificourse, meticulosamente, que se tinha o acordo do interlocutor". ${ }^{54}$ Vemos que na sofística o interlocutor poderia se utilizar de perspicácia para fugir da responsabilidade da tese. Se Sócrates perguntasse o que é $X$ a um amigo e não tivesse anteriormente determinado que não teria importância alguma se a tese que ele está sugerindo seria dele ou não, este amigo assumiria o compromisso de tomá-la para si. Poderia dizer durante o exame que, por não ter falado em seu próprio nome, não assumiria a responsabilidade da tese apresentada, abandonando-a nesta dada parte da pesquisa. Quando se é pedido que os interlocutores assumam suas próprias opiniões, Sócrates tem o objetivo de que eles mesmos assumam a responsabilidade da pesquisa, com o objetivo de que uma única opinião, a que eles mesmos defendem, seja tomada na investigação. Isso tem por objetivo evitar jogos erísticos durante a pesquisa, evitar o simples prazer de disputar apenas por disputar sem compromisso com a verdade, e evitar ainda mais a confusão e a indeterminação de que Ildefonse fala. Sobre isso, podemos citar Vlastos que compartilha dessa mesma opinião: "o elenchos é a primeira e última pesquisa. O procedimento adversário que é sugerido, mas que não está

\footnotetext{
${ }^{54}$ Ildefonse, Protagoras, (1997): "La confusion et l'indétermination en la matiére sont une des ressources de la sophistique - si, par exemple, une personne tente de se défaire d'un accord qu'elle a donné, en prétendant qu'elle n'a pas alors parlé en son nom propre, sans pour autant avoir prévenu que c'était le cas. D'où la manière dialectique, qui repose, étape après étape, sur des points pour lesquels on a méticuleusement vérfié que l'on avait l'accord de l'interlocuteur".
} 
implicado, pela palavra grega - que pode ser usada com o significado de 'refutação', mas também 'teste', ou ainda mais restrito 'censura', 'reprovação' - não é um fim em si mesmo. Se isso fosse assim, a dialética socrática, como descrita nos primeiros diálogos, deveria ser uma forma de torneio verbal - 'eristica' - o que não é". ${ }^{55}$ Vlastos concorda que a pesquisa socrática não é uma justaposição de crenças, opiniões ou idéias em que tais posições dos interlocutores são solicitadas unicamente com o objetivo de serem refutadas. Sócrates não tem o prazer de solicitar que seus interlocutores respondam à suas perguntas simplesmente para se sobrepor. É como Vlastos revela, o elenchos não tem um fim em si mesmo. A refutação socrática não visa a pura e simples refutação, e ele não tem por objetivo apenas refutar seus companheiros. No Carmides ele deixa isso bem explícito. Nessa passagem, Crítias observa que na argumentação socrática existe uma questão problemática. Valendo-se disto, Crítias faz a seguinte acusação: “tu não procuras senão me refutar, sem te preocupares com o objeto da discussão" (eme. gar epiceirei'| elvegcein, easaj peri.ou-o'logoj estin, 166c). Sócrates dá sua réplica: “Qual idéia, eu disse, tu te aplicas a seguir? Se muitas vezes te refuto, não é a fim de apenas refutar, mas outro, investigar o que eu mesmo digo, temendo crer, cegamente. saber alguma coisa que eu não sei. É o que faço neste momento, examinar o pensamento, sobretudo, em meu próprio interesse, e, igualmente, no interesse de meus outros amigos: não crês ser um bem comum para quase todos os homens vir a tornar evidente o conhecimento de cada coisa em seu modo de ser? (oi an, ha d' egw. poieil' hàgumenoj, eivofi malista se. evegcw, allou tinoj eheka elvegcein h. ouper eheka kvan emauton dier eunwmhn ti, legw, foboumenoj mh, pote I agw oiomenoj men ti eidenai, eidwj de. mh.

\footnotetext{
${ }^{55}$ Vlastos (1983): "elenchus is first and last search. The adversary procedure which is suggest, but not entailed, by the Greek word - which may be used to mean 'refutation', but also 'testing', or still more broadly 'censure, reproach' - is not an end in itself. If it were, Socrates' dialectic as depicted in the earlier dialogues would be a form of verbal jousting - 'eristic' - which is not" p. 39.
} 
kai. nuh dh. ouf egwge, fhmi touto poiein, ton logon skopeih malista men emautoul eheka, iswj de.dh.kai.twh all wn epithdeiwnl h.ouvkoinon oiei agagon ei ai scedon ti pasin anqrwpoij, gignesqai katafanej ekaston twh ontwn ophlecein; 166c-d). Observamos que existe um objetivo que não está muito explícito. Este alvo é o que, precisamente, Sócrates procura alcançar, e isto que está oculto vai por uma via completamente distante da que sugere Vlastos.

Sócrates não tem compromisso somente com a refutação, mas também com a verdade, a verdade moral. Vlastos também acredita nesse ponto: "na erística, onde o principal objeto é vencer, qualquer um está livre para dizer qualquer coisa que the dará uma vantagem no debate. No elenchos, onde o principal objeto é a busca por verdade, ninguém tem essa opinião. Alguém pode dizer no que acredita - ou seja, no que alguém julga como verdadeiro - mesmo que venha a perder no debate". ${ }^{56}$ O objetivo da refutação socrática é bem preciso, ela visa a busca pela verdade. O mérito de quem participa da investigação elênctica está no ato de atingir a finalidade da pesquisa, ele não se encontra no fato de ser o vencedor na discussão. O prêmio é o que é alcançado, em conjunto, nesta jornada: a verdade.

Além de querer evitar esse turbilhão de opiniões, Sócrates tem outra coisa em mente que é preciso ser considerada. Devemos notar que Sócrates considera sempre um único e mesmo critério para toda e qualquer investigação. Em qualquer pesquisa ele se guia ou procura uma coisa determinada. Esta coisa que ele procura é uma verdade e, em se tratando dos Diálogos socráticos, essa verdade deve ser necessariamente uma verdade moral. Aqui, encontra-se a nossa primeira solução, a qual sugerimos

\footnotetext{
${ }^{56}$ Vlastos(1983): "In eristic, where the prime object is to win, one is free to say anything that will give one a debating advantage. In elenchus, where the prime object is to search for truth, one does not have that option. One must say what one believes - that is, what one thinks true - even if it will lose one the debate", p. 43-44.
} 
anteriormente, para o objetivo de Sócrates (S1). Sócrates tem o objetivo de encontrar a verdade das coisas investigadas. Deve-se assumir uma opinião, num primeiro passo, para evitar que se tenha várias interpretações para um mesmo objeto. Se esta opinião ou crença é do próprio interlocutor ou não, isso é o que menos importa, já que o que Sócrates deseja encontrar é a verdade. O Carmides (161b-c) dá um bom exemplo disso: Carmides: (...) Neste instante, pois, me lembrei - uma coisa que já ouvi dizer que Temperança seria fazer as coisas que lhe são próprias. Considere, então, se isto te parece ter sido dito corretamente. (...:A rti gar a nemnhsqhn - o]hdh tou hkousa legontoj - ofi swfrosunh va. eih to.ta. eàtou/prattein. skopei oun touto eivorgw|' soi dokei/l egein o'l egwn.)

Sócrates: Impuro! Eu disse. É do próprio Crítias que ouviste isso ou de um outro sábio. (K ai, eVtgw。 +W miare, ef hn, K ritiou toude akhkoaj auto. K. al I ou tou twh sof wh.)

Crítias: Parece, disse Crítias, de um outro, pois, certamente, não foi de mim. (E oiken, ef h o'kritiaj, alloul ouvgar dh.emou/ge.)

Carmides: Mas em que difere, Sócrates, disse Carmides, de quem eu ouvi? (VA II a.ti, diaf er ei, $h=d^{\prime}$ ol, o ' C armidhj, w =S wkratej, of ou hkousa;)

Sócrates: Em nada, eu disse: pois não examinamos isso que ele disse completamente, mas se um ou o outro diz a verdade ou não. ( 0 u den, h $\#$ d' egw pantwj gar ouvtouto skepteon, optij auto, eifen, abla. poteron abhaej I eget a i h.ou:)

Carmides relembra uma opinião que não é a sua. Essa opinião que é posta na investigação é de um outro qualquer que, neste caso, Carmides ouviu outrora falar, ela não é propriamente deste interlocutor, ele não a retirou de si mesmo. O que deveria acontecer é que Sócrates o repreendesse e exigisse que ele mesmo expusesse o que ele 
mesmo creria ser a Temperança. Este é o procedimento que deveríamos esperar se seguíssemos o que foi exposto por Vlastos. A pesquisa só deveria prosseguir se Carmides abandonasse essa idéia, que não é sua, e por si mesmo, unicamente por isso mesmo, desse continuidade à investigação. Porém, a reação de Sócrates é completamente contrária, e aquilo que esperávamos acontecer não se dá no texto apesentado. Carmides indaga: de que importa de quem seja? Sócrates conclui: não importa de quem seja, não importa de quem quer que seja essa opinião. É preciso verificar se isso que foi dito, se essa tese que foi apresentada é verdadeira ou não. Esse é o objetivo de Sócrates, procurar a verdade, e suas próprias palavras revelam isso: "se um ou outro diz a verdade ou não" (poter on alhqej l egetai h. ou;).

Mas o Carmides não é o único Diálogo que revela isso. Em Eutífron (14e) e Protágoras (333b-c) encontramos essa mesma idéia. Comecemos pelo Eutífron: ${ }^{57}$

Sócrates: A Piedade seria, Eutífron, uma espécie de técnica de comércio entre os deuses e os outros homens. (E mporikh.ara tij Van eih, w=E uquf rwn, tecnh h'osiothj qeoill par' ahlh|wn.)

Eutífron: Que seja comércio, se te apraz chamá-lo assim. (VE mpor ikh, ei oufw j halion soi onomazein.)

Sócrates: Nada agrada a mim mesmo, se não identifica-se com o que é verdadeiro (...). (Vall' ouden hblion emoige, ei mh.tugcanei alhaej on.)

Ora, o que deveríamos, mais uma vez, esperar desse trecho do Eutífron? Era de se esperar, como sugere Vlastos, que somente a crença do interlocutor interferisse na pesquisa. Era de se esperar que Sócrates nesse momento interferisse e repreendesse o

\footnotetext{
${ }^{57}$ Muitos comentadores identificam o mesmo tipo de atitude por parte dos interlocutores de Sócrates nestas passagens do Protágoras e do Eutífron. As personagens se servem de expressões como "se te agrada", no Protágoras, e no Eutífron, quando a personagem homônima se expressa da seguinte forma: que seja chamado de comércio, "se te apraz chamá-lo assim".
} 
que foi dito por Eutífron, ou seja, o se te agrada não deveria influenciar na pesquisa. Mas ao invés de repreender Eutífron, o que era de se esperar, Sócrates expõe seu verdadeiro objetivo, que é encontrar a verdade. Como ele mesmo disse: "Nada agrada a mim mesmo, se não identifica-se com o que é verdadeiro".

Verificaremos agora como isso ocorre em um outro Diálogo socrático. Utilizaremos uma passagem do Protágoras (333b-c) para reforçar nossa tese:

Sócrates: O homem que faz uma injustiça é prudente quando faz essa injustiça? (aka, tij soi dokeiladikwh angrwpoj swfroneih, of i adikeik)

Protágoras: Eu, Sócrates, disse ele, enrubesceria de admitir, mas muitas pessoas o admitem. (aiscunoimhn Van egwg', ef $h$, wh S Swkratej, toutto omologein, epei.polloi,ge, fasin twh angrwpwn.)

Sócrates: A quem eu levaria em conta, a eles ou a ti? poter on ouf proj ekeinouj ton I ogon poihsomai, ef hn, h.proj se;)

Protágoras: Se tu o desejas, replicou ele, começa por discutir a opinião destas pessoas. (eivboulei, ef h, proj touton prwton ton logon dial ecghti ton twh pol I wh.)

Sócrates: A mim pouco me importa, basta-me que sejas tu que respondas, se esta é ou não a tua maneira de ver; porque é a tese que examino antes de tudo, e também pelo fato de nos encontrarmos ambos submetidos ao mesmo tema, eu em perguntar e tu em responder. (all' ouden moi diagerei, ean monon su, apokrinhl eit' ouf dokei/soi tauta eite mhl ton gar logon egwge malista exetazw, sumbainei mentoi iswj kai. eme.ton apokrinómenon exetazesqai.)

A questão posta por Sócrates mostrourse espinhosa. Protágoras, literalmente, manifesta sua insegurança ao sugerir a opinião da multidão. Por que, nesse momento, Sócrates não censura esta sugestão de Protágoras, já que ele esta propondo que seja 
examinado entre eles a opinião da multidão? Sócrates não deveria aceitar que a pesquisa fosse guiada tendo por base a opinião da multidão, por um terceiro interlocutor mudo que não tem como ser analisado e refutado. Tal procedimento era o esperado. Verificaremos o que Vlastos, para essa passagem, sugere como interpretação, diz ele: "Quando Protágoras estava procurando o mesmo tipo anterior de abrigo na segurança astuta de sua resposta, 'se você quiser'; Sócrates bloqueou o movimento, indicando que Protágoras já tomou uma posição e deve estar seguro dela: seu ego está agora na linha, como deve ser no elenchos, pois, de outra maneira, Sócrates deveria fazer restar uma proposição imparcial de uma pessoa pronta para afirmar sua vida sobre isso, e isto Sócrates deve recusar, como de fato ele recusou neste momento. Uma vez que está tudo esclarecido, Sócrates está pronto a fazer concessões, como um pis-aller e, sob protesto, o argumento deve continuar: é permitido a Protágoras salvar sua pele para ceder seu lugar a esta substituta 'multidão' sem face". ${ }^{58}$ Valendo-se dessa afirmação, pretendemos ir contra Vlastos em relação a duas considerações dele:

i) sobre ele desconsiderar as opiniões da multidão;

ii) por chamar esse recurso de Sócrates, de um pis-aller, um tapa-buraco. ${ }^{59}$

${ }^{58}$ Vlastos (1983): "When Protagoras was looking for the same kind of shelter earlier on by hedging his answer with 'if you wish', Socrates had blocked the move, indicating that Protagoras had already taken a stand and would be held to it: his ego was now on the line, s in elenchus it must, for otherwise Socrates would be left with a proposition detached from a person willing to predicate his life on it, and this Socrates would refuse, as in fact he did refuse at the time. Once that is settled, Socrates is willing to make concessions, as a pis aller and under protest, so that the argument may go on: Portagoras is allowed to save face by handing his part over to that faceless surrogate 'the multitude'. For the same reason Socrates lets the same thing happen again, and on a bigger scale, later in the dialogue, where Socrates directs his argument for the impossibility of acrasia to the same notional answerer, 'the multitude', dragging along as a make-believe ally (352e ff.). at the end of that debate we see that Socrates takes the consequence to be that Protagoras has been 'examined' after all, compelled to confess that his thesis - not just that of the 'multitude' - has been shown to be 'impossible' (360e)”, p. 45.

${ }^{59}$ Ildefonse (1997) diz, de acordo com a opinião de Vlastos, que: "En deux occasions, précise G. Vlastos (1991, p. 159), Socrate tolère une infraction à la règle qui consiste dans le fait de « croire ce que 
Sobre (i), é evidente que a multidão esta abstida da pesquisa. Ela não tem como tomar partido na investigação, ela é um interlocutor sem face e sem voz - sua face e sua voz são representadas pelos interlocutores. Porém, não é a multidão que está sendo julgada nesse caso, assim como não é Protágoras. Se não se trata de nenhum desses, quem seria ou o quê estaria sendo analisado nesse caso? Sócrates diz: "é a tese que examino antes de tudo". Na investigação que preza pela verdade, não é permitido desconsiderar as opiniões que surgem no decorrer da mesma. Ele não poderia não analisar as opiniões, ou premissas, de quem quer que seja. Sócrates não pode tomar partido a favor de um determinado tipo de opinião apenas, ele deve ser imparcial com as que lhe são apresentadas. Qualquer que seja a tese, uma vez posta para ser analisada deve ser destrinçada até às últimas conseqüências. Mesmo que a tese seja infundada, como, por exemplo, as aporias de Zenão, ela deve ser investigada, e isto é um procedimento necessário para verificar onde esse fundamento falha. Por isso, recusamos a explicação de Vlastos de que o que Sócrates rejeita são determinadas proposições. Na investigação, qualquer outra coisa poderá ser recusada, o que não é permitido é que as premissas, as teses, as proposições sejam.

Sobre (ii), o que Vlastos quis dizer quando afirma que, nesse momento da investigação, Sócrates utiliza-se de um tapa-buraco para dar prosseguimento à pesquisa? Seria uma tolerância, por parte de Sócrates, à infração cometida por Protágoras, como foi interpretado por Ildefonse? ${ }^{60}$ Se falarmos que se trata de uma tolerância, estaríamos admitindo que na pesquisa não temos a seriedade esperada, já que ser tolerante não implica ser rigoroso. Toda pesquisa, para ser boa, necessita ser

l'on dit », c'est-à-dire de s'investir dans sa thèse - et il ne s'agit, précise G. Vlastos, que d'un pis -aller", cf. sua nota de tradução 207, Protagoras, Flammarion. O ponto que pretendemos ressaltar nesta citação é o fato de Ildefonse tratar a questão como ela mesma fala: “uma infração à regra”. Isso será analisado logo a seguir.

${ }^{60}$ Cf. nota 52. 
rigorosa, donde não pode ser permitido assumir que esse recurso de Sócrates seja um tapa-buraco. É o mesmo que abandonar uma dificuldade na investigação simplesmente por ser uma dificuldade. Não podemos levar a sério algo que sirva como tapa-buracos.

A observação de Ildefonse quanto a esse ponto, a exposição das próprias opiniões, parece ser mais promissora. Nossa opinião segue a mesma linha de raciocínio de Ildefonse de que não apenas as crenças pessoais devem ser expostas, mas também as de um outro que não está presente. Segundo essa pesquisadora, isso compõe a lógica do que ela nomeou de investimento dialético: "a lógica do investimento dialético exige que nós o enderecemos à pessoa que está presente, que não represente senão ela mesma - ou que, a menos que saibamos a quem exatamente, nós nos endereçamos, se ela fala ou não em nome de uma outra pessoa ou de uma outra instância". Esta lógica do investimento dialético que o método exige pode ser endereçado tanto para o interlocutor presente quanto à opinião daquele que não participa da pesquisa. Donde ela afirma que "o investimento tem lugar, desde que o interlocutor fale, qualquer que seja a relação que ele mantenha com a tese que ele sustente". ${ }^{61}$ A tese é retirada do interlocutor e o importante é que ele responda. Isto é reforçado na afirmacão de Ildefonse: qualquer que seja a relação que o interlocutor tenha com a tese que ele suscite, que ele sustente, que ele trate, dentro da discussão, o investimento dialético será acionado. Ela também assume uma posição que não difere muito da de Vlastos: “A maneira com a qual aquele que responde deve responder implica, igualmente, que o interlocutor da conversa dialética se investisse nas posições que ele sustenta: o acordo deve ser inteiro, livre,

\footnotetext{
${ }^{61}$ Dorion, Lachès, (1997) La maniére « dont celui qui répond doit répondre » implique également que l'interlocuter de l'entretien dialectique s'investisse sans restriction dans les positions qu'il soutien: l'accord doit être entier, libre, sincére. Dans le premier argument, Socrate rejette violemment l'accord de complaisance que Protagoras s'apprête à lui concéder: «Ce ne sont pas des "si tu veux" et des "s'il te semble" que je souhaite éprouver, mais c'est toi e c'est moi.» Plus tard, dans le cours du dialogue, Socrate nuancera cette règle absolue - sans pour autant lui retirer sa validité" (...) "l'investissement a lieu, dès que l'interlocuteur parle, et quel que soit le rapport qu'il entretien à la thèse qu'il soutient", p. 56-57.
} 
sincero". Porém, ela vai direto a um ponto importante que essa sua afirmação implica. Como pretendemos demonstrar, esse esforço de Sócrates é o desvio necessário do caminho da indeterminação própria da sofística. Quando uma das regras, antes de iniciar a pesquisa, é falar em seu próprio nome, os adversários não podem, com isso, sair sorrateiramente da investigação. ${ }^{62}$

O que queremos ressaltar, portanto, é que Sócrates novamente reverencia que o que deve ser considerado como importante na pesquisa é a busca pela verdade. Não é o interlocutor, nem Sócrates, e muito menos a multidão que estão sendo analisadas. Está bem claro, explicito, e incontestável o que realmente importa: "é a tese que examino antes de tudo", fala Sócrates no Protágoras. O compromisso na investigação é com a verdade. São as premissas que são examinadas, e não é do interesse de Sócrates descobrir de onde ela veio, assim como também não o é que ela rigorosamente surja apenas dos interlocutores, que ela seja uma invenção exclusiva deles.

Com isso pretendemos ter saído do impasse do qual falamos, como conciliar o fato de que ao mesmo tempo Sócrates exige que seus interlocutores exponham suas próprias crenças para que a pesquisa tenha continuidade, com o fato de que não é necessário, para dar continuidade à pesquisa, que os interlocutores exponham tais crenças exclusivamente. É necessário que as teses que serão apresentadas sejam assumidas por seus representantes, e esse deve ser o procedimento para evitar que o foco da pesquisa seja desviado. Mesmo que elas não sejam criações dos interlocutores, quem as proferir deve assumir a responsabilidade sobre elas até o momento em que seja demonstrada sua insuficiência ou não (esse foco em qualquer pesquisa, não importa qual seja, é a verdade). Se é esse o compromisso da pesquisa, não importa de quem é a tese analisada, ela será, como toda e qualquer outra, analisada.

\footnotetext{
${ }^{62}$ Cf. nota 48 .
} 
Não se trata, portanto, de verificar se as opiniões sustentadas pelos interlocutores se chocam umas com as outras, e que o objetivo da investigação socrática teria por fim identificar essa incoerência no grupo de opiniões dos seus adversários. Expressar as próprias opiniões em um dado momento tem por finalidade evitar os jogos erísticos, em outro momento esse procedimento indica que a busca tem por fim alcançar a verdade. $\mathrm{O}$ critério de verdade que pretendemos defender tem por fim alcançar a unidade de uma multiplicidade. Esta unidade é alcançada ao ser encontrada a identidade que é peculiar a determinados grupos de coisas. Sabemos que esta identidade é a essência real da coisa investigada, a qual se identifica com a definição real de tal coisa, de modo que o critério de verdade socrático está fundado nesta definição real. No Mênon, Mênon tenta contra-argumentar a definição de Sócrates de Figura. Sócrates afirma que a figura é "o único entre os seres que acontece sempre acompanhar a cor [75b]", Mênon não é a favor desta definição porque ela tenta esclarecer o que é a figura, que é uma coisa até então desconhecida, por outra que é desconhecida, neste caso, a cor. Sócrates responde da seguinte forma à objeção de Mênon: “o mais dialético seja não só responder a verdade, mas também por meio de coisas que aquele que é interrogado admita que sabe [75b]". Sócrates deseja a definição de X, com base em conhecimentos já pressupostos. Se, para definir o que é a figura como "o único entre os seres que acontece sempre acompanhar a cor”, for necessário definir, também, a cor, e tendo definido a cor, for notado que para outros elementos da definição de cor é forçoso defini-los também, a pesquisa prossegue ad infinitum.

Os elementos da definição são arranjados de forma a obedecer a critérios logicamente pré-estabelecidos. Se dissermos que "Sócrates é um animal dotado de asas e voa" como resposta a uma pergunta do tipo, “quem é Sócrates?", já temos conhecimento de alguns termos. Sabemos o que é um animal, Sócrates e asas antes 
mesmo da pergunta, e portanto da resposta, e sabemos com toda a segurança que esta resposta que damos como exemplo é totalmente falsa. Podemos fazer tais conclusões porque, e é o mais importante, sabemos as relações entre estes termos. Para chegarmos à definição, esperada por Sócrates, de X, temos que tomar por base alguns pressupostos, nossos conhecimentos anteriores das coisas, extraídos dos pré-conhecimentos identificados com as opiniões verdadeiras. 


\section{Conclusão}

Tendo sido feitas as mediações necessárias - como, por exemplo, saber o que Sócrates deseja alcançar quando faz sua questão primária, se seria uma essência, qual tipo de essência (nominal ou real) etc. - poderemos chegar a duas conclusões que ajudarão a iluminar o paradoxo da unidade das virtudes. A primeira é a verificação de que não é apenas o método elênctico, em sua mais pura forma - a negação por si mesma - o único método empregado por Sócrates, por este caráter puramente refutativo, e que o elenchos é um momento de um outro método do qual este faz parte. A segunda é a demonstração das insuficiências das duas teses clássicas que tentam expor a verdade velada pelo paradoxo da unidade das virtudes. Após estas duas conclusões exibiremos uma indicação interpretativa que não tem, ainda, a pretensão de desvelar esta verdade, mas de ser uma leitura possível.

\section{Por que negar o Método Elênctico?}

A primeira resposta não satisfaz a Sócrates. Para sabermos, mais precisamente, qual é o motivo, vamos verificar isso nos Diálogos. No Laches, após Sócrates ter perguntado “o que é a Coragem?”, a personagem homônima deste Diálogo responde da seguinte forma: "se, pois, um homem deseja, permanecendo em seu posto, lutar contra seus inimigos e não foge, esteja certo que será um homem corajoso ( ei vgar tij eqel oi en thltaxei menwn amunesqai touj pol emiouj kai. mh. f eugoi eu=isqi oti andreipj van ei h , 190e). No Eutífron, a resposta à pergunta o que é a Piedade é a seguinte: "digo que, certamente, Piedade é o que faço nesse momento: perseguir um culpado de um crime, seja um assassino, seja o furtador de objetos sagrados ou quem cometa qualquer 
outro erro desse gênero, seja o pai ou a mãe que tenha feito isso ou um outro qualquer. Impiedade é não perseguí-los" ( egw toinun ofi to. men os̀ion estin oper egw. nuh poiw/tw/adikounti $h$. peri, fonouj h. peri, ièrwh klopaj hiti allo twh toioutwn examartanonti epexienai, eante pathr wn tugcanhleante mhthr alloj ostisouh, to.de. mh. epexi enai anoșion, 5d-e). No Carmides, a resposta à pergunta o que é a Temperança é a seguinte: "a Temperança consiste em fazer todas as coisas de forma bem ordenada e serena, seja ao caminhar pelas ruas e ao dialogar, seja, da mesma maneira, ao fazer todas as outras coisas. Parece-me, disse, que o que me perguntas, em geral, é uma espécie de placidez" (swf rosunh ei ai to. kosmiwj panta prattein kai. hs̀uchl, en te tail odoil badizein kai. dialegesqai, kai, ta, alla panta wsautoj poiein. kai, moi dokeib ef h, sullhbdhn hśuciothj tij ei zai o] erwtal, 159b). As repostas de Eutífron e Laques apresentam uma característica comum. A identidade entre elas está no fato de que ambas recorrem a dados sensíveis, ou melhor, a exemplos de atos corajosos, piedosos. Estas personagens recorrem, para um mesmo objeto, a exemplos dos mais diversos e variados. A resposta de Carmides será deixada de lado, por enquato, porque apresenta uma resposta mais sofisticada do que as apresentadas por Eutífron e Laques.

No caso destes dois primeiros Diálogos, a insatisfação por parte de Sócrates surge por dois motivos. O primeiro é que um dado sensível ou exemplo de um ato virtuoso, qualquer que seja esse ato, não diz o que é a coisa investigada, é apenas algo que faz parte do todo desta coisa. Se Laques afirma que corajoso é aquele que permanece firme em seu posto, não diz muito ou quase nada do que seja a Coragem, ele apenas indica uma porção do todo que é a Coragem. O segundo motivo é que a resposta não corresponde ao tipo esperado por Sócrates, este tipo é explicado por Sócrates em Mênon, como expõe Robinson (cf. p. 50). No Mênon, depois de Sócrates ter perguntado o que é a Virtude, Mênon tenta responder-lhe utilizando-se de exemplos de atos 
virtuosos. Citar atos virtuosos não é suficiente para dizer o que é a Virtude, ainda que alguém possa citar todos estes atos, mesmo que todos esses atos fossem reunidos conjuntamente não teríamos com isso a virtude investigada. Essa é uma das insatisfações de Sócrates, mas, além disso, ele demonstra como deve ser dada essa resposta. Ao perguntar o que é a Figura, uma boa resposta deve ser como esta: "a figura é o limite do sólido" (76a). O motivo desta resposta ser boa é que ela tenta compreender tudo o que deve ser uma figura, ou seja, qualquer figura, não importa qual seja, deve ser o limite do sólido. Decorre disso que a resposta que Sócrates procura extrair das coisas observadas é aquilo que lhes é comum. Ele se utiliza dos critério "um sobre vários" e "X ele mesmo". Neste exemplo da figura, a reposta é satisfatória porque toda e qualquer figura tem em comum a característica de ser o limite do sólido, ou seja, o círculo antes de tudo é o limite do sólido, o quadrado, além de ser quadrado, é o limite do sólido e assim deve ser, necessariamente, toda e qualquer outra figura. Para que Laques alcance o que Sócrates aspira ele deve tentar encontrar o que existe de comum entre os atos corajosos para, assim, dar uma resposta satisfatória. Essas primeiras premissas que são dadas pelos interlocutores de Sócrates não correspondem ao que é aspirado porque não exprimem este algo comum em todas as esferas da coisa que está sendo investigada. Mesmo que Carmides apresente uma resposta mais sofisticada, uma vez que ela atende ao critério "um sobre vários", no sentido de ser uma tentativa de exprimir este único X sobre os vários Xs, ela, não atende, em absoluto, ao critério "X ele mesmo", pois não conseguiu atingir a essência da Temperança. Na verdade, tanto um quanto o outro critério tentam atingir a essência de X. É isso o que o exemplo de Sócrates no Mênon tenta expor, "não compreendes que procuro aquilo que é o mesmo em todas essas coisas?" Ouvmanqaneij ofi zhtw/to. epi. pabin toutoij tauton, 75a), e Robinson 
ressalta: "isto que é o mesmo em todos os Xs". ${ }^{63}$ É necessário verificar em todos os tipos de Xs o que eles têm em comum, ou seja, qual forma distintiva, que sempre é a mesma, existe neles. É preciso encontrar a Forma socrática de X.

Essa procura pelo mesmo em todas as coisas, ou melhor, a essência real das coisas, também está presente nos Diálogos aqui estudados. No Eutífron, antes que Sócrates faça a pergunta o que é a Piedade, ele adverte: "não é o mesmo em toda ação o próprio pio, e o pio não é o contrário de todo pio, e ele mesmo não é semelhante a si mesmo. Tendo uma forma única segundo a natureza ímpia, justamente, por isso, todo [ímpio] está destinado a ser ímpio?" (ouvtauton estin en pash|praxei to. ok ion autro. autwl kai.to. amosion austou/men osiou pantoj enantion, auto. de. autw/omoion kai. econ mian tina.idean kata. thn anosiothta pah ofiper van mell hlanosion ei ali 5d). No Laches, Sócrates também indica o mesmo procedimento para a resposta a ser dada: “empreendemos novamente em dizer, em primeiro lugar, o que é a coragem, que é a mesma em todas estas circunstâncias" (pal in oü peirw/ eipeih adreian prwton ti. V. en pasi toutoij tautron estin, 191e). Além disso, Sócrates exemplifica como Laques deve proceder: "se, em algum momento, te pergunto o que é a ligeireza; é aquela que se encontra no correr, no tocar a cítara, no falar, no aprender e em muitas outras coisas, e nós a possuímos em quase tudo que se trata disso, seja nos exercícios de nossas mãos, das pernas, da boca, da voz ou do pensamento" (w\$per Van eivtacoj hrwtwn ti, pot, estin, o]kai. en twltrecein tugcanei vo hmin kai. en tw/kigarizein kai. en tw/legein kai. en tw/manqanein kai. en alloij polloil, kai. scedon ti autro. kekthmega, ou-kai. peri axion legein, h. en tail twh ceirwh praxesin $h$. skel wh h. stomatoj te kai. fwnhl K.dianoiaj, 192a).

\footnotetext{
${ }^{63}$ Robinson (1941), p. 50: "that which is the same in all the Xes".
} 
Os esforços dos interlocutores, sua tentativa de definir os objetos investigados, não foram em vão, ao chegarem a esse ponto em que não atingiram a meta que deve ser alcançada. Este procedimento que é indicado por Sócrates revela que as teses suscitadas inicialmente pelos interlocutores não são de todo negadas. Fine compartilha da mesma opinião nas seguintes palavras: “a definição nem sempre é rejeitada. No Laches (197ac), por exemplo, a definição em consideração (que a Coragem é Sabedoria) é mantida, e o ponto de vista de que os leões são corajosos (uma opinião a partir de exemplos) é rejeitada. Nem sempre é uma definição que é testada. No Criton, por exemplo, uma questão prática (se Sócrates deve fugir da prisão) é investigada" ${ }^{64}$ A importância dessa nota é que Fine assume que: a definição não é toda rejeitada, ou melhor, a verdade que ela possui permanece durante toda a investigação. ${ }^{65}$ Não se trata de mostrar que tal tese ou qualquer outra é negada, mas que ela é insuficiente ou não está capacitada para ser considerada como a melhor forma de responder ao pedido de Sócrates. Para alguns estudiosos, não apenas a tese não serviria aos propósitos de Sócrates como também seria completamente abandonada após a refutação. Contudo, consideramos esta interpretação insatisfatória. Se tomarmos uma premissa $p$ como resposta à questão “o que é $X$ ?" e notarmos que ela é insuficiente porque existe $q$ e $r$, isso não demonstra que $p, q$ e $r$ são falsas, já que estas premissas estão incluídas na noção de $X$. Se essas premissas fossem falsas, elas não poderiam ocupar o lugar de exemplos de $X$. Vamos

\footnotetext{
${ }^{64}$ Nota 3 do texto de Fine, G., Plato I, Introduction, p. 2: "the definition is not always rejected. In the Laches (197a-c), for example, the definition under consideration (that courage is wisdom) is retained, and the view that lions are courageous (a belief about examples) is rejected. Nor is it always a definition that is tested. In the Crito, for example, a pratical question (whether Socrates should flee from prison) is investigated".

${ }^{65}$ Vlatos em seu Socrates' Disavowial of knowledge (1985) afirma o seguinte: "nor yet invalidate the fragmentary truths unearthed alon the way”, p. 81. Vemos neste trecho que esse comentador afirma que as verdades, ao longo da investigação, são desveladas. Nem tudo é de todo dispensado, negado, descartado na análise de Sócrates. Muitas das coisas analisadas demonstram ter nelas algo de verdadeiro. Temos esta mesma opinião.
} 
observar isso no exemplo sobre a velocidade. Se perguntarmos o que é a velocidade e a resposta for correr bem rápido, tal resposta não será suficiente porque não só no ato de correr se é veloz, mas, também, em outros domínios. Não provamos com isso que a premissa "correr bem rápido" é falsa, pois se ela fosse falsa não poderia ser considerada com um modo em que a velocidade se expressa. Quanto a este ponto, Vlastos não concorda com Robinson ${ }^{66}$, afirmando: "o que Sócrates de fato faz num dado elenchos não é condenar $p$ por sua falsidade, mas por ser um membro de um grupo inconsistente de premissas". ${ }^{67} \mathrm{O}$ objeto da pesquisa pode se manifestar de vários modos, por isso é necessário observar nesses vários modos o que eles têm em comum. Se $p, q$ e $r$ são formas de $X$, o que é esse $X$ que se apresenta como $p, q$ e $r$ ?

Se isolarmos o elenchos e considerarmo-lo apenas em seu sentido refutativo, ele será puramente negativo. Sua natureza negativa, realmente existente, consiste em destronar de seu posto premissas que não correspondem inteiramente ao objeto investigado. Se "permanecer firme no seu posto" não é a melhor resposta para dizer o que é a Coragem, o negativo está aí presente no momento em que tal premissa não pode ocupar este lugar. Considerar o elenchos como puramente regativo é pensar que o objeto a ser investigado nunca será alcançado. Porém, se uma dada premissa não está capacitada a dizer o que é o objeto investigado, é de se notar que, de alguma forma, exista uma que o diga. Existe uma negação, mas seu objetivo é encontrar o $X$ que se procura. Como diz Vlastos: “o elenchos é a primeira e última pesquisa. O procedimento adversário que é sugerido, mas que não está implicado, pela palavra grega - que pode ser usada com o significado de 'refutação', mas também 'teste', ou ainda mais restrito ‘censura', 'reprovação' - não é um fim em si mesmo. Se isso fosse assim, a dialética

${ }^{66}$ A objeção de Vlastos incide sobre a seguinte declaração de Robinson (1941): "he habitually thought and wrote as if all elenchus consists em reducing the thesis to a self-contradiction", p. 28.

${ }^{67}$ Vlastos (1983), p. 38. 
socrática, como descrita nos primeiros diálogos, seria uma forma de torneio verbal 'eristica' - o que não é". ${ }^{68}$ Se o elenchos, de acordo com Vlastos, fosse puramente negativo, ele teria uma característica típica dos jogos erístico e seu objetivo seria o de alcançar a vitória, a derrota de seus adversários ou a refutação apenas por refutar. A investigação socrática tem um fim, e esse fim é a verdade. O elenchos não apenas nega, mas é por esta negação que ele nos conduz a um fim que não é apenas a pura negação. Por isso Vlastos diz que tal método não tem um fim em si mesmo, a refutação socrática não tem o fim de refutar. Para entendermos isto, tomemos o exemplo o ato de esculpir em um bloco de concreto. $\mathrm{O}$ ato de esculpir corresponderia ao ato de negar, já que a forma original (o próprio bloco) estaria sendo modificada, mas ao ser esculpida, uma outra forma estaria sendo atingida. O fim da escultura não seria o ato de esculpir, mas sim a escultura. Da mesma forma, no elenchos o fim não é o próprio ato de refutar, mas a descoberta do que é $X$. Como Robinson expõe, não importa qual seja o método, o meio ou qual forma de conhecimento utilizado, todos têm um fim a ser alcançado. ${ }^{69}$

Goldschmidt reconhece três modos de refutação, a saber: o argumento et alia, o argumento et oppositum e o argumento et idem non. Ele define o argumento et alia da seguinte forma: "ele consiste em recusar uma imagem produzindo imagens concorrentes em que as mesmas pretensões, à primeira vista, parecem inteiramente legítimas". ${ }^{70} \mathrm{~A}$ refutação, nesse caso, se utilizaria de uma outra premissa concorrente com essa primeira. Por exemplo, se quisermos refutar a premissa "a cor é o azul”, podemos alcançar isso admitindo que a cor não pode ser o azul porque existem outras cores. Da

\footnotetext{
${ }^{68}$ Idem, p.39.

${ }^{69}$ Como declara Robinson, todo método que pertence a uma techne ou episteme apresenta uma mesma característica: "may be generally described as rational selfconscious human activity pursuing by indirect means some foreseen end that cannot be attained directly", e acrescenta, "an end or purpose is essential to both art and method. Without something to be achieved they cannot occur”, p. 62 .

${ }^{70}$ Goldschmidt (2002), p. 36.
} 
mesma forma, não podemos dizer que a Virtude é a Justiça porque existem outras virtudes e assim por diante. $\mathrm{O}$ argumento et oppositum é aquele que se utiliza, como Goldschmidt se expressa, de uma "contra-imagem”, a refutação neste argumento é dada valendo-se de uma premissa oposta à primeira. Quando Laques diz que Coragem é o ato de permanecer firme em seu posto, Sócrates refuta essa premissa com uma outra que lhe é oposta, dizendo que corajoso não é apenas aquele que permanece firme, mas também aquele que foge. $\mathrm{O}$ último argumento, et idem non, revela que a primeira premissa demonstra-se imperfeita frente a uma mais determinada, como no caso das respostas dadas por Carmides. A refutação ocorre porque atende ao critério de verdade socrático. Se uma dada tese não ocupa um determinado lugar, próprio para esta, na classe dos conhecimentos prévios, a doxa verdadeira, é necessário encontrar uma tese que ocupe tal lugar. Se temos a classe "homem" e a classe "animais alados", não podemos dizer que uma pertence a outra. Este é o critério de verdade que debatemos anteriormente.

O interessante desses argumentos refutativos que Goldschmidt delimita é que eles demonstram a insuficiência da utilização dos dados sensíveis na investigação. Além disso, eles também nos mostram que o ponto de partida dessas premissas são, propriamente, esses dados. Como ele diz: "as hipóteses devem apoiar-se tanto sobre as coisas sensíveis como sobre as imagens". ${ }^{71} \mathrm{O}$ importante aqui é ressaltar a necessidade desses dados, e isso o próprio Sócrates recomenda quando ele pede a seus interlocutores que procurem nas coisas múltiplas o que elas têm em comum. Conclui-se, com isso, que o método que Sócrates emprega recorre, antes de tudo, às coisas sensíveis. Primeiramente, deve-se recorrer a elas, observando-as minuciosamente para, desta forma, identificar o que há de comum entre elas. No Laches, Sócrates pede para que a Coragem seja reconhecida em todos os domínios em que ela é aplicada: "isto que falei a

\footnotetext{
${ }^{71}$ Idem, ibdem.
} 
pouco, sou responsável por não te ser exato de modo conveniente, por não ter te interrogado justamente. Quero te inquirir não somente sobre os homens corajosos na infantaria, mas, também, na cavalaria e em todas as formas do corpo militar. Não só ao que é corajoso em ralação ao combate, mas, também, em ralação ao que é corajoso quanto aos perigos do mar. Quanto àqueles que são corajosos frente à doença, à pobreza, a política. Ainda, não só aqueles que são corajosos frente às dores ou os medos, mas os que lutam contra os desejos e prazeres terríveis, seja permanecendo firme, seja ao dar meia volta" (touto toinun o] arti el egon, ofi egw. aitioj mh. kal wi se apokrisnasqai, ofi ouvhromhn-boulomenoj gar sou pugesqai mh. monon touj en twl oṕlitikw/andreiouj, ahla.kai.touj en tw/ippikw/kai. en sumpanti tw/polemikw/eidei, kai. mh. monon touj en tw/pol emw palla,kai, touj en toil proj thn qalattan kindunoij andreiouj ontaj, kai. okoi ge proj nosouj kai. okoi proj peniaj h. kai. proj ta. politika, andreipi, eisin, kai. eti au=mh. monon oboi proj I upaj andreipi, eisin $h$. fobouj, abla. kai. proj epiqumiaj h. hdonaj deinoi. macesqai, kai. menontej kai. anastref ontej, 191c-d). Aqui, vemos Sócrates assumindo a necessidade dos dados sensíveis como parte fundamental da investigação. É valendo-se deles que o interlocutor deve proceder na pesquisa, já que é a partir deles que se pode dizer o que é o objeto da investigação, é neles que identificaremos a identidade existente entre estes tipos. É essa identidade, esse comum nestes dados sensíveis, o próprio objeto investigado, o próprio $X$. Mas nem sempre esse é um procedimento válido, já que podemos partir de premissas universais, porém, nos servindo de nossas opiniões verdadeiras.

É possível, neste momento, estabelecer algumas considerações relevantes quanto às características próprias do método aplicado nos Diálogos socráticos:

1) É necessário se servir dos dados sensíveis para se atingir uma resposta válida para a questão “o que é $X$ ?”; 
2) Quando a resposta é inconsistente com o que se espera, é necessário a refutação da tese, demonstrando ou como ela deve ser respondida ou a invalidade da resposta;

3) A refutação não tem um fim em si mesma.

Isoladamente, o elenchos é puramente negativo. Se pensarmos a refutação por si mesma, ela cumpre a função de apenas negar. Mas, nos Diálogos, essa negação não aparece isolada. Nota-se que ela cumpre esse papel refutativo, mas além disso, ela nos encaminha a um objetivo. Este objetivo, já sabemos, é o de encontrar o que é esta coisa que está sendo investigada, a saber, a definição e essência real de X, o universal. Aqui, podemos observar que existe uma positivação. Logo, no elenchos existe um movimento duplo, um negativo e outro positivo, sendo que este negativo nos direciona a este positivo. Mas, além desse positivo aspirado existe uma outro tipo. Durante o processo de investigação, premissas são negadas, porém não é uma negação feita de forma irresponsável, deixada à sorte, ela é bem direcionada e bem pensada. Robinson declara: “este uso para eliminar das instâncias é largamente uma questão negativa. Um resultado afirmativo é obtido somente depois de muitos negativos". ${ }^{72}$ De uma premissa $p$ chega-se a uma $M$ bem mais determinada do que a primeira. Nisso também se encontra um positivo, já que uma dada premissa é negada para que outra bem mais desenvolvida e mais próxima do objeto apareça, ou melhor, para que surja uma nova bem mais próxima da verdade, "ou para torná-la mais precisa". ${ }^{73}$ Em suma, existem duas formas de positivação: o fim a ser alcançado e o processo que se utiliza de novas premissas até atingir esse fim esperado. $\mathrm{O}$ puramente negativo não é o único elemento presente na investigação socrática, pois através dele é impossível de se escapar ao positivo. Se

\footnotetext{
${ }^{72}$ Robinson (1953), p. 44: "this eliminative use of instances is largely a negative affair. An affirmative result is obtained only after many negatives".

73 idem, ibdem: "or to render it more precise".
} 
refutamos uma tese indiretamente com base na seguinte fórmula: se toda Coragem fosse permanecer firme, então, já que a fuga é um tipo de Coragem, fugir deve ser um ato de permanecer firme em seu posto. Porém, fugir não é o mesmo que permanecer firme; portanto, toda Coragem não pode ser "permanecer firme em seu posto". A tese, Coragem é permanecer firme, foi refutada indiretamente, este é o momento do negativo na investigação, mas também, foi estabelecida de forma indireta que nem toda a Coragem é permanecer firme, este é um dos momentos de positivação na investigação. Vlastos ressalta que na própria essência contida em determinadas palavras gregas, que são aquelas intimamente relacionadas à própria investigação, está expressa essa necessidade da positivação. Tal declaração é feita logo após ele assumir que o elenchos não tem um fim em si mesmo. É desta forma que ele se expressa: "porque seu objetivo é sempre este alcance positivo por verdade que é expresso por palavras como pesquisar (erveunw / di er eunw), questionar (zhtw b erwtw / suner w tw ), investigar (skopw b di a skopw b skeptomai, diaskeptomai). Isto é o que filosofia é para Sócrates". ${ }^{74}$ É inevitável que qualquer um que se proponha a investigar qualquer coisa tem a necessidade de alcançar esta coisa investigada. Quando alguém investiga, pesquisa, questiona tem por objetivo alcançar a verdade, tem um fim positivo. Podemos retirar disso que o método aplicado nos primeiros Diálogos de Platão não se limita a fazer com que se demonstre a insuficiência de uma tese, não apenas em contra-argumentar ou refutá-la, ele vai além disso e possui outros elementos além da negação. Nosso esforço será o de determinar o que seriam estes outros elementos.

Provavelmente a solução para o problema do que seria este outro elemento que compõe a investigação esteja no que a própria pergunta socrática implica. Mas o que

\footnotetext{
${ }^{74}$ Vlastos (1983), p. 40: "because its object is always that positive outreach for truth which is expressed by words for searching (eveunw b di er eunw ), inquiring (zhtw /, erw tw /, s uner w tw ), investigating (skopw /, di askopw /, skeptomai , di askeptoma i ). This is what philosophy is for Socrates".
} 
existe na pergunta socrática que nos dará a solução para esse problema? A solução está precisamente no que ela procura. Já sabemos que seus objetivo são: descobrir o que é $X$ e o que decorre deste primeiro ponto, saber o que há em comum nas coisas em que esse $X$ se apresenta, encontrar esse $X$. O que viria a ser essa busca pelo que há de comum nas coisas? De que forma poderíamos expressar o que é esse comum? Podemos assumir que o que se procura é aquilo que sustenta as coisas, que subjaz, que esse comum é a essência delas. Esse esforço deve procurar reconhecer na multiplicidade das coisas a identidade que existe nelas. Quando reconhecemos esse comum, esse idêntico, saímos da esfera da multiplicidade em direção a uma unidade, portanto a questão socrática busca o comum, o idêntico, a essência, o universal das coisas sensíveis, ou ainda, a unidade. Como foi discutido na seção 1.4.2 desta dissertação, o que Sócrates procura é a essência real de $X$. Logo, o processo necessário para se alcançar a essência real de $X$ é composto de: pressupostos (dados sensíveis, opiniões verdadeiras), que serão a base de informações necessárias; o elenchos, que se apresenta principalmente como refutação indireta; o estabelecimento de uma tese, uma positivação e, por fim, a epagoge. Concluímos que o método elênctico não é o único aplicado nos Diálogos socráticos. É o que Hall afirma na seguinte declaração: "a definição de um conceito é o tipo de verdade que era tipicamente buscada por ele, e ele suplementa seu elenchos com outra técnica, posteriormente chamada epagoge (evpagwgh,) por Aristóteles. Este consistia em levar o oponente a uma generalização, conduzindo-o a aceitar a verdade de uma série de proposições sobre casos particulares". ${ }^{75}$

${ }^{75}$ Hall (1967), p. 386 : the definition of a concept is the sort of truth that was typically sought by him, and he supplement his elenchus with another technique, latter called epagoge (evpagwgh,) by Aristotle. This consisted in leading the opponent on to a generalization by getting him to accept the truth a series of propositions about particular cases. 


\section{Por que nenhuma das teses Satisfaz?}

Valendo-nos das teses clássicas da unidade das virtudes nos primeiros escritos de Platão e seus respectivos representantes, iremos neste momento apresentar algumas dificuldades que decorrem destas e, portanto, nas interpretações de seus respectivos defensores. Iniciaremos esse esforço objetando a tese da Bicondicionalidade na forma como Vlastos a apresenta. De forma geral, a tese que este autor defende determina que a unidade das virtudes está fundada numa relação lingüística. Para tal estudioso, os sentidos da palavra "ónoma" ilumina o paradoxo da unidade das virtudes. Ele considera que ónoma é tanto o termo que é tomado como referência quanto o termo que é tomado como descrição do termo que é referência, de forma que Justiça é [descritivamente] Piedade, ou seja, o nome "Justiça" é nomeado descritivamente pelo nome "Piedade". Assim como esta mesma relação é verdade para "Justiça", deve ser verdade para todas as outras virtudes. Com isto, temos cinco nomes ("Sabedoria", "Justiça", "Piedade", “Coragem" e "Temperança") de uma única e mesma coisa, de um único termoreferência ("Sabedoria" ou "Justiça" ou "Piedade" ou "Coragem" ou "Temperança"). ${ }^{76}$ Há duas objeções à leitura de Vlastos. A primeira é que Sócrates procura a essência, ou definição, real das coisas investigadas, não interessa para Sócrates a essência nominal. A segunda é que estabelecer essas relações entre os termos referenciais e os termos descritivos revela que estes termos estão inter-relacionados, mas o que funda esta relação não se encontra simplesmente no estabelecimento de tais relações. Devemos

${ }^{76}$ Vlastos teria que considerar o que está dito no Laches: tu deste tua resposta pensando que a Coragem é uma parte, e que também existem outras partes, que todas juntas são chamadas virtude ?. O que existe de incrível aqui é que ele confirma o que é dito no Protágoras, que são cinco nomes diferentes de uma única coisa. Se elas são chamadas de virtude isso pode ser verdade. Talvez isso revele que não se trata de uma relação entre os termos referências e suas descrições, mas de um único termo referência ("Virtude”) e suas descrições (“Sabedoria", "Justiça”, "Piedade”, “Coragem” e "Temperança”). 
pensar que, para que elas existam, antes de tudo, é necessária uma relação lógica entre os termos que permita tal elo de ligação. Além disso, existe uma relação que escapa à tese defendida por Vlastos. Talvez, ela tenha se limitado apenas a interpretar a unidade das virtudes no Protágoras, mas ela não pode se estender, por exemplo, para o Eutífron, em que Sócrates estabelece que a Piedade é uma parte da Justiça, e, com isso, a extensão do termo Justiça ultrapassa a esfera do campo que compreende a Piedade. Não seria aconselhável pensar que Justiça é [descritivamente] Piedade, já que nem toda Justiça é Piedade. Acreditamos que as virtudes estão bicondicionalmente relaciondas, tendo uma tem-se todas, mas não da forma como é apresentada por Vlastos, pois sua interpretação não implica a identidade entre as virtudes. $\mathrm{O}$ que é o próprio objetivo socrático nas suas investigações.

Contra a tese de Penner, atendemos que não podemos considerar que o que Sócrates procurava era o significado da palavra "coragem". Penner confunde o significado da palavra com sua essência e seu universal. Se considerarmos que o que Sócrates procurava era o significado, temos que considerar que Sócrates procurava a essência nominal de Coragem, o que não é verdade, porque os termos que são utilizados na investigação são todos anteriormente conhecidos.

Ferejohn soube fazer boas objeções à interpretação de Penner. Nesse momento, nossas objeções a Penner são as mesmas que Ferejohn fez. Primeiramente, Penner se esforça em negar o que ele chamou de "ponto de vista do significado" e, mormente, os elementos que seriam peculiares a esta interpretação, a saber, que a busca socrática visava a essência, definição ou o universal. Segundo Penner, não era esse o interesse de Sócrates, mas sua investigação tinha por fim encontrar isso em virtude do que os homens tornavam-se corajosos, sábios, temperantes, justos ou piedosos. Para Penner, tratava-se de um único e mesmo estado psicológico que está presente em todo e 
qualquer ser humano. Mas se essa única coisa que cobre todos os homens, esse estado psicológico, não for um universal, o que será? É o que Ferejohn considera quando fala que "Penner não dá nenhuma razão qualquer para supor que este estado piscológico (que é, depois de tudo, capaz de ser compartilhado por muitos indivíduos e assim por diante é um universal) não pode ele mesmo ser o universal coragem, a única coisa que cumpre a função tal que o significado do termo 'coragem"'. ${ }^{77}$

Deve ser notado que a questão socrática implica uma exigência por aquilo que torna cada ato virtuoso corresponde à sua virtude, assim como cada pessoa virtuosa é virtuosa por causa de uma virtude determinada. Por exemplo, as pessoas corajosas são corajosas devido à Coragem. Sócrates não estaria procurando o que faz com que as pessoas corajosas realizem atos corajosos, mas o que as torna assim. É o que Ferejohn declara: "o que é exigido por esta questão é isto em virtude do que as pessoas corajosas são corajosas, e não isto em virtude do que as pessoas corajosas agem corajosamente" e acrescenta: "este estado não deve ser a causa da coragem; ele deve constituí-la. O que deve ser causado pelo específico estado psicológico talvez devam ser as ações corajosas, e o que deve causar o estado de coragem devem ser tais coisas como o exercício e o treino". ${ }^{79}$ Este estado somente faz parte da Coragem, e no sentido que

${ }^{77}$ Ferejohn (1995), p. 417: "Penner gives no reason whatever for supposing that this very psycological state (which is, after all, capable of being shared by many individuals, and so is a universal) cannot itself be the universal courage, the very thing that functions as the meaning of the term 'courage",

${ }^{78}$ Ferejohn (1995), p. 418: "what is asked for by this question is that because of which courageous persons are courageous, and not that because of which courageous persons act courageously".

${ }^{79}$ Ferejohn (1995), p. 418: "that state would not cause courage; it would constitute it. What would be caused by the specified psycological state would perhaps be courageous 
interpretamos esta parte não é idêntica ao todo, já que lá onde está o todo não está a parte.

Uma contra argumentação à interpretação de Penner é a de Zingano. Penner assume que Sócrates não tinha por objetivo alcançar a essência da coisa investigada. Para Zingano, quando Sócrates revela que a virtude toda inteira é o conhecimento do bem e do mal, tal conhecimento, que é idêntico a todas as virtudes cardinais, é propriamente a essência destas. Estamos de pleno acordo nesse ponto. A busca pelo idêntico na investigação socrática é a busca pela essência de X.

As objeções a Ferejohn serão as mesmas que faremos a Zingano, pois consideramos que ambos possuem uma mesma interpretação para o paradoxo da unidade das virtudes. ${ }^{80}$ Para Zingano, como expusemos:

Sabedoria $=$ conhecimento do bem e do mal;

As virtudes são uma única e mesma sabedoria;

A diferença é dada pelos domínios em que esta sabedoria é aplicada;

Coragem é o conhecimento do bem e do mal aplicado aos objetos do temor; Justiça é o conhecimento do bem e do mal aplicado às trocas e ao comércio entre os homens; Temperança é o conhecimento do bem e do mal aplicado aos prazeres do gosto e do tato.

Uma única e mesma virtude apresenta-se em diversos domínios que compõem a esfera desta virtude. Deste modo, uma única e mesma Coragem apresenta-se em diversos domínios que compõem sua esfera; por exemplo, é uma única e mesma Coragem em todas as situações de perigo na guerra;

actions, and what would cause the state of courage would be such things as upbringing and training.

${ }^{80}$ Ambos assumem que a distinção entre as virtudes particulares é contingente, já que é determinada por elementos extra-cognitivos, como, por exemplo, os meios em que o conhecimento é aplicado. 
De acordo com a interpretação de Zingano, a Coragem é a mesma em todos os domínios em que é aplicada, e a diferença é dada exatamente por estes domínios em que esta Coragem se aplica;

Mas Coragem $=$ Sabedoria;

Logo, é a Sabedoria que é aplicada a estes domínios referentes aos perigos da guerra.

Assim, não podemos dizer que temos partes, já que com isso teríamos que nos comprometer a dar nomes a todos os atos $\mathrm{x} 1, \mathrm{x} 2, \mathrm{x} 3, \mathrm{x} 4 \ldots$ que acontecem no tempo $\mathrm{t} 1$, t2, t3, t4... e que são realizados pelos sujeitos s1, s2, s3, s4... nas circunstâncias c1, c2, c3, c4... Pelo número infinito de permutações e possibilidades, falar de partes é uma prática fadada ao impossível. Sabemos que cavalo enquanto cavalo é apenas um único cavalo; se sua diferença é dada pelo que existe nestes animais de acidental, para cada ente-cavalo singular deveríamos ter um único nome que cada um destes entes-cavalo deve possuir para representá-lo. No caso das virtudes não pode ser diferente. Como não podemos nomear cada domínio singular em que cada virtude particular se aplica, não podemos nomear os domínios específicos que cada virtude particular nomeia. Assim todos os atos corajosos não podem ser nomeados de corajosos, os temperantes de temperantes, assim por diante. A possibilidade é nomear todos estes domínios apenas com o nome de Sabedoria. Assim, Sabedoria é o conhecimento dos bens e dos males referentes aos objetos do temor, às trocas e ao comércio entre os homens e aos prazeres do gosto e do tato. Deste modo, Sabedoria é o conhecimento de todos os bens e os males. Os acidentes não podem determinar o que existe de essencial na coisa. Se Sócrates assume no Carmides que a quietude não pode ser o que é próprio da ação temperante, ela não pode ser aquilo que torna as ações temperantes temperantes, andar pelas ruas com brandura não é o que torna, ou o que causa, neste ato temperante o ser- 
temperante. Ao contrário, é a Temperança que o torna temperante. No Eutífron encontramos isso de forma explícita quando Sócrates pede a Eutífron que ele defina a Piedade recorrendo a "esta forma mesma em virtude da qual todas as coisas pias são pias" (6d). No Carmides: "Neste momento é necessário, Carmides, que tu recomeces a observar em ti mesmo com uma atenção redobrada; pois, quando tu tinhas observado o efeito que a temperança produz em ti por sua presença e o que ela deve ser para te tornar o que és, e que tu te estarás preparado para dar conta de tudo isso. Tu nos dirá claramente e bravamente o que crês que ela seja" (160d-e). É através da Forma socrática da Piedade, o pio-ele-mesmo ou o único pio entre os vários pios, que as coisas pias são pias, e não o contrário. Outro indício é a seguinte passagem do Protágoras: "quando os homens agem de maneira correta e útil, crês tu que sejam eles temperantes, conduzindose assim, ou o contrário? - Eles são temperantes, disse ele. - Não é devido à Temperança que são temperantes?” (332a-b).

Parte dos comentadores admite que possuir as virtudes torna quem as possui virtuosos. De acordo com a interpretação de Zingano, as partes da virtude só passam a existir no momento em que a Sabedoria é aplicada a um domínio determinado. Quando alguém não está agindo, temos apenas o conhecimento do bem e do mal. Tornamos-nos corajosos somente quando aplicamos este conhecimento em momentos de terror. Assim, a virtude Coragem teria que estar submissa ao domínio em que ela é aplicada para poder ser Coragem. Antes e depois da ação só temos Sabedoria, de forma que não é possível ter consciência do ato corajoso nem antes nem depois do ato. Mas ao mesmo tempo, ser corajoso é ter o conhecimento do que seja a Coragem, ser temperante é ter o conhecimento da Temperança, e o mesmo vale para todas as outras virtudes. Se somos corajosos, temperantes, justos etc., apenas possuindo o conhecimento destas virtudes, não precisamos da ação para nos tornamos como tal. Porém, as virtudes só se efetuam 
durante o ato, pois é a aplicação do conhecimento a determinados domínios. Se tomarmos o Mênon (74b-75a), em que Sócrates toma a tentativa de definir o que é a figura como um paradigma, ele afirma o seguinte: "antes, já que chamas essas muitas coisas por um só nome, e que afirmas que todas elas são figura, e isso ainda quando são contrárias umas as outras - que é isso que de modo algum compreende menos o redondo do que o reto, isso precisamente que chamas figura, <de tal forma que > afirmas que em nada o redondo é mais figura que o reto? [74d]". Estas muitas coisas que Sócrates fala são as figuras, o redondo, o reto, o quadrado etc., todas estas figuras possuem um caracter distintivo comum, possuem uma identidade. Todas elas são nomes de uma única coisa, mas isso não nos permite dizer que todas estas figuras são uma única e mesma coisa. Da mesma forma, não podemos assumir que assim se procede na relação entre as virtudes.

Interpretamos que esta essência real que Sócrates procura não depende de outros elementos exteriores a ela, pois se dependesse não seria uma essência. Sócrates “está assumindo que esta forma ou essência ou o um nos vários, não é uma palavra na boca, nem um conceito na cabeça, mas algo que existe nos particulares Xs independentemente dos homens". ${ }^{81}$ Estamos de acordo com esta posição de Robinson. Independente do homem e da ação essas formas existem, se um homem morre, envelhece ou qualquer coisa, elas continuarão existindo, da mesma forma se tal ou tal ato ocorre ou não, se é feito por tal ou tal indivíduo.

Nossa leitura conclui que as teses existentes que tratam do problema da unidade das virtudes nos primeiros Diálogos de Platão contêm seus momentos de verdade. Concordamos com Vlastos que Sócrates deseja uma relação bicondicional

${ }^{81}$ Robinson (1953): "is assuming that this form or essence or one in the many is not a word in the mouth, nor a concept in the head, but something existing in the particular Xes independently of man”, p. 57. 
entre as virtudes. Da mesma forma, temos a convicção que todo o esforço de Sócrates é a busca pelo idêntico nas coisas, e que nas virtudes o "idêntico" é a Sabedoria que, a qual por sua vez é idêntica ao conhecimento do bem e do mal. Somos partidários da declaração feita por Zingano de que a inseparabilidade (ou bicondicionalidade) das virtudes não implica a identidade entre elas, mas a identidade implica a sua inseparabilidade. Como Ferejohn, pretendemos conciliar tanto uma quanto a outra tese sob um certo aspecto. De um lado, defendemos que Sócrates deseja a identidade e, por outro, que esta identidade não implica a dissolução da diferença entre as virtudes, já que Sócrates fala de partes da Virtude. Por maior que a identidade seja, sob um certo aspecto, a diferença entre as virtudes, por menor que seja, é absoluta. Cada virtude distinta é uma essência distinta de todas as outras virtudes e da Virtude inteira; assim como os nomes que representam cada virtude distinta são nomes essencialmente diferentes. Por isso, duas virtudes particulares são ao mesmo tempo idênticas e distintas entre si, designam definições distintas, constituem universais distintos, os quais são tão essencialmente diferentes como duas idéias as mais opostas. Mas a identidade revela um único elemento: o conhecimento do bem e do mal ou que todas elas são ciência.

\section{Dialética}

Nossa hipótese interpretativa considera que o método elênctico não é o suficiente para dar conta da questão da unidade das virtudes nos primeiros escritos de Platão, por estar contido nestes Diálogos outros elementos além do elemento puramente negativo. Acreditamos que estes outros elementos compõem um único e mesmo método que inclui o elênctico. Notamos que o esforço socrático é o de atingir esta essência, 
definição e, mais do que tudo, este universal. Especificamente, quanto à natureza da unidade das virtudes, interpretamos que a relação entre as virtudes particulares e a Virtude toda inteira está fundada nesta relação entre particular e universal. Com isto, apresentamos as insuficiências das teses clássicas que tratam desta questão, pois nenhuma delas conseguiu dar conta de alguns problemas interpretativos que conflitam entre o Protágoras e o restante dos Diálogos aqui analisados. Nossa hipótese considera que este nétodo é o dialético, diríamos que o método dialético contém o elênctico. Robinson faz tal afirmação: "a razão porque Platão constantemente expõe ao ridículo a erística e a distingue da dialética é que em verdade sua própria dialética, muito intimamente, aparenta-se com a erística; e isto, passo a passo, é porque sua própria dialética, embora tendo um propósito construtivo, incorpora o destrutivo elenchos socrático",82.

Assumir esta hipótese interpretativa é o mesmo que lidar com uma série de problemas. Entre estes está a diferença entre o Sócrates histórico e Platão. Os comentadores recorrem à divisão própria dos Diálogos para revelar que os primeiros escritos de Platão é a reprodução da filosofia socrática, os outros revelam posição propriamente platônica. ${ }^{83}$ Sabe-se que o diferencial mais marcante entre os Diálogos socráticos e os platônicos é a chamada Teoria das Idéias. Como Robinson fala: "repetidas falhas no esforço de descobrir qualquer essência particular somente aumentou a excitação de Platão e sua certeza que as essências estivessem aqui. Ele,

\footnotetext{
${ }^{82}$ Robinson (1953), p. 85-86: "the reason why Plato constantly pillores eristic and distinguishes it from dialectic is that in truth his own dialectic very closely resembled eristic; and this in turn is because his own dialectic, thouh having a constructive purpose, incorporates the descructive Socratic elenchus" Cf., também, n. 83.

${ }^{83}$ Hall (1967) apresenta as seguintes características como sendo exclusivas de Sócrates, e declara não existir uma continuidade na filosofia platônica: "the Socratic irony, or pretense not to know anything and not to be conducting a refutation, was a personal feature of Socrates' dialectic and contributed nothing to later developments", p. 386.
} 
desta maneira, veio introduzir um elemento que não é encontrado, de qualquer forma, nos primeiros diálogos, a saber, a reflexão sobre a essência em geral, ou a essência como um corpo, como opondo-se ao concentrar-se habitualmente em uma essência particular; e estas reflexões são o que é chamado de Teoria das Idéias de Platão" ${ }^{84}$

Mesmo que seja apresentada esta diferença entre a filosofia socrática e a platônica, consideramos que desde os primeiros escritos até a fase mais amadurecida de Platão este filósofo mantém um mesmo esforço. Acreditamos que desde sempre a dialética está presente em todo o corpus das obras de Platão, mesmo que ela sofra algumas modificações, por exemplo ela é entendida como método hipotético nos Diálogos intermediários ou como diaíresis nos últimos. Mas toda a dialética, como está apresentada nos primeiros Diálogos que compõem nosso estudo (Protágoras, Laches, Carmides e Eutífron) e nos outros Diálogos de Platão, obedece a um princípio, ela busca o universal das coisas particulares, reconhecendo-o como a essência real das coisas. A diferença entre Sócrates e Platão é dada da seguinte forma como expressa Dorion: "é um universal, mas a este eîdos não está atada nenhuma das dimensões ontológicas e epistemológicas da teoria das formas inteligíveis". ${ }^{85}$ As formas, sejam elas socráticas ou platônicas, apresentam a mesma lógica, a saber, todas são universais. A lógica de cada uma das formas seja socrática ou platônica, é a mesma para ambas, ${ }^{86}$ ou melhor, se retirarmos das formas platônicas seu estatuto ontológico, elas passam a ser formas socráticas. Portanto, o critério da dialética platônica apresenta as mesmas

\footnotetext{
${ }^{84}$ Robinson (1953), p. 53: "Repeated failures in the effort to discover any particular essence only increased Plato's eagerness and his certainty that the essences were there. He thus came introduce an element not found in early dialogues at all, namely reflection on essence in general, or the essence as a body, as opposed to concentrating always on one particular essence; and these reflections are what is called Plato's theory of Ideas".

${ }^{85}$ Dorion (1997), p. 211: “c'est un universel, mais à cet eîdos n'est attachée aucune des dimensions ontologiques et épistémologiques de la théorie des formes intelligibles."

${ }^{86}$ Cf. n. 24. estamos de acordo com esta interpretação de Dixsaut.
} 
características básicas do que se encontra nos diálogos socráticos, nós temos em ambos o estabelecimento das teses, o silogismo, o elenchos, a epagoge, a essência.

Outro ponto em comum é que toda dialética busca "o que cada coisa é" (Rep. 533b), que é o mesmo que procurar a essência de cada coisa (ousía, Rep. 534b). Robinson declara: “'filosofia’ significa para Platão ou a busca por excelência moral, ou a busca por excelência intelectual ou ambas". ${ }^{87}$ Logo, para Platão, assim como para Sócrates, a dialética busca a essência das coisas - em Platão, outras essências podem ser buscadas, além da essência das excelências morais - e o ponto em comum entre os dois é a busca pela essência real da Virtude e suas partes. O que podemos retirar dessa afirmação de Robinson é que tanto nos Diálogos socráticos quanto nos intermediários e de maturidade a investigação tem por objetivo encontrar a essência das coisas. O que seriam as Idéias senão as essências das coisas deste plano sensível? As Idéias são precisamente as essências, o universal das múltiplas coisas sensíveis. Logo, considerando-as como tal, identifico a busca nesses Diálogos de juventude como a busca pela essência ou o universal das coisas. A diferença que Robinson identifica é que a essência aspirada nos primeiros Diálogos é o que ele chama de "particular essence", essência particular, ao contrário da que é aspirada nos outros que seria a essência em geral ou a essência como um corpo. Platão ressalta essa característica da dialética: "este é um outro método, que tenta, em todos os casos, apreender, por processo científico relativo a cada objeto, a essência de cada um" (Rep. 533b).

Em Platão não temos termos que representem "universal" e "particular", ele estabeleceu termos diferentes para uma mesma relação: a relação entre a "unidade" (eh), o "comum" (koinhl) e a "semelhança" (omoioj, prosepiken) de um lado; e as "partes"

\footnotetext{
${ }^{87}$ Robinson (1953): 'Philosophy' meant to Plato either the pursuit of moral excelence or the pursuit of intellectual excellence or both.
} 
(mo r i a ), o "em si mesmo" (a uth,) e a "distinção" (di a f or on ) por outro. A mesma relação é encontrada em outros diálogos: no Laches, entre a sumpanta e as moria; no Carmides, que assemelha-se ao Laches, quando estabelece que a Temperança apresenta-se como o conhecimento do bem e do mal, sendo que continua a relação todo (conhecimento do bem e do mal) e parte (neste caso a Temperança); no Eutífron, entre a justiça e a piedade, ou entre o Número e o ímpar. O estabelecimento destes dois planos (termos mais universais de um lado e mais particulares de outro) parece-nos metodologicamente decisivo, pois acreditamos que todas essas relações revelam que o esforço de Platão é por estabelecer uma relação entre a universalidade e a particularidade, ou seja, a sua busca pela unidade das virtudes revela-se, por um lado, como busca pelo universal entre as virtudes; e, por outro, a busca pelas "partes" revela-se como uma investigação que se esforça por determinar a particularidade de cada virtude, sua especificidade.

Acreditamos que o Eutífron apresenta, exatamente, a solução que pretendemos encontrar. Ele demonstra três ordens de relações: a primeira, entre a piedade e a justiça; a segunda, entre o temor e a reverência; a terceira, entre o número ímpar e o número. Esta terceira relação é a que mais nos interessa, pois cumpre a função de uma racionalidade metodológica daquelas duas primeiras. Como Sócrates expõe, o Ímpar é uma "parte", mori ion, do Número, ou melhor, o Ímpar é um particular na sua relação com o universal, que é o Número. A primeira coisa que precisamos determinar é se o Número é o "conjunto" - como sugerem os termos sumpanta e morion no Protágoras e no Laches - destes tipos de números ou uma outra coisa. Ora, o Número (o universal dos tipos particulares de números: o Par e o Ímpar) não pode ser entendido como constituindo um mero "conjunto" destes tipos de números. Vejamos por que. Se tomarmos os tipos de números pares e ímpares, podemos verificar que eles são as formas mais universais com relação aos outros números; em outras palavras, nos 
números Reais, nos Irracionais etc., sempre estão presentes o Par e o Ímpar. A união ou o conjunto de todos os números Pares com os Ímpares não é o suficiente para determinar o que é o Número, a mera junção das partes particulares, o Ímpar e o Par, não esgota o conceito de Número. O Número está presente nos números Pares, nos Ímpares, nos Reais etc. Nesta citação, Sócrates deixa isso bem claro: "a reverência é parte do temor, assim como o número Ímpar é parte do Número; de sorte que, lá onde existe Número, o Ímpar não está, mas lá onde existe Ímpar o Número está" (mo r i on ga r aidwj deouj wsper arigmou/peritton( wste our ihaper arigmoj enga kai.perittonl iha de. peritton enqa kai. arigmoj) [12 c]. Pelo fato de o universal estar presente nos particulares, ele não pode ser compreendido como o "conjunto" ou "junção" dos particulares, pois se tomássemos, por exemplo, "par" (p), "ímpar" (i), "racional" (r) como elementos de um conjunto "Número" $(\mathrm{N})$, então $p$ conteria $N, i$ conteria $N, r$ conteria $N$. Mas, como seria possível considerarmos que $N$ seja o conjunto de $p, i, r$, se o próprio $N$ está contido em cada um desses elementos? Esta seria, naturalmente, uma conclusão inaceitável. Por esta razão, o Número não pode ser entendido como um "conjunto" de todos os números, como uma relação de "todo" e "partes", assim como a Justiça não é o "conjunto" formado pela Piedade e pelas outras formas particulares da Justiça. Se assim o fosse, seria forçoso admitir que só teríamos a Justiça quando tivéssemos suas partes ao mesmo tempo, de forma que não poderíamos declarar que um indivíduo será justo na outra parte que compreende a Justiça.

Nesta nossa interpretação da relação entre Número e Ímpar, desejamos explicitar o que não está plenamente desenvolvido na relação que Sócrates estabelece entre as moria e o sumpanta. Ele recorre à argumentação do Número, apesar de não estar expresso de forma explicita na sua argumentação, com o objetivo de demonstrar que a racionalidade desta relação se apresenta como fundamento para as outras que ele 
pretende estabelecer. Esta relação será exatamente o modelo que nos possibilita, tomando-a como base, o conhecimento da maneira pela qual devemos proceder ao desejarmos estabelecer a relação entre a justiça e a piedade, entre a reverência e o temor etc., e, mormente, entre a unidade das virtudes e suas partes. Portanto, a relação Número e Ímpar pode ser entendida como uma relação entre uma universalidade e uma particularidade, e não entre um conjunto e seus elementos/partes, que pode ser constatada na relação entre as ações piedosas e o eîdos da piedade, ou como uma relação entre um universal e outro, que pode ser constatada na relação entre a piedade e a justiça, entre a virtude inteira e suas partes etc.

Ora, como entender que o Número esteja presente nos números particulares, ou melhor, como é possível que o universal esteja presente no particular? Para determinarmos o que é o universal, é necessário determinar o que existe de comum nos particulares. Por exemplo, para sabermos o que é o Número devemos observar o que existe de comum entre o Par, o Ímpar e os demais tipos de números. Este comum é exatamente o Número. Se o Número não estivesse totalmente presente nos casos particulares, se ele não fosse totalmente, inteiramente número em sua presença nos tipos particulares de números, então os Pares, os Ímpares etc., não seriam números. A mesma coisa não seria possível se considerássemos que apenas parte do Número esteja presente nos particulares, pois não é aceitável que ali exista a metade do Número ou é completamente número ou não será número, não podemos falar de uma identidade parcial. Da mesma forma, os tipos ou formas particulares de números apenas serão números se o Número estiver totalmente presente neles. Se o Número não estiver completamente nestes tipos particulares, como no Ímpar e no Par, estes deveriam ser classificados como uma outra coisa que não números. 
A diferença entre os particulares só existe na medida em que eles participam do universal. Se não existe esta participação, então estaríamos tratando de coisas de naturezas diversas. O Ímpar é Número, assim como o Par é Número. Onde termina o Ímpar, ou temos o Número ou temos o Par, pois o Ímpar não é o Número, nem o Par é o Número. Dito de outro modo, o não-Ímpar implica ou no Número ou no Par, assim como o não-Par implica ou no Número ou no Ímpar. Contudo, o não-Número implica na inexistência do Ímpar, do Par e de todos os números particulares.

Aplicado à discussão sobre a Justiça e a Piedade, isso quer dizer que onde está a Piedade encontramos a Justiça por completo e, onde termina a Piedade, encontramos ou uma outra forma particular da Justiça ou a Justiça em si. Se considerarmos a Piedade uma forma particular da Justiça (não uma "parte" de um "conjunto" chamado Justiça), onde não existe a Justiça, tampouco existe a Piedade. Mas, o fato de a Justiça estar por completo na Piedade, não significa que ambas são uma única e mesma coisa, como demonstram as exigências socráticas do critério "X ele mesmo". Logo, a Justiça não é a Piedade, a Piedade não é a Justiça; da mesma forma, nas relações da Virtude toda inteira, o conhecimento do bel e do mal, e suas partes - seja como aparece no Laches ou no Carmides.

Expomos, em linhas gerais, a interpretação que nos parece a mais verdadeira. Nosso trabalho apresenta-se como o elenchos socrático, ele muito mais refuta do que estabelece uma tese positiva. O universal é apreendido apenas pelo intelecto, assim, ele pode ser apresentar como um conhecimento. Se tivermos o universal "Virtude" nós temos necessariamente as suas formas menos universais, as formas particulares nesta relação, a saber, Sabedoria, Justiça, Piedade, Temperança e Coragem. Se pensarmos homem, peixe, cavalo, pássaro e dissermos que são particulares do universal animal, não teremos onde se encontra cavalo todos os outros animais, mas, inteligivelmente, 
onde temos cavalo, temos animal, onde temos homem, temos animal, onde temos pássaro, temos animal, e assim por diante. Onde temos animal, temos todos os outros porque todo animal para ser animal deve pertencer à essência "animal". Assim, aplicamos esta mesma lógica para as virtudes e a Virtude toda inteira. Nossa pesquisa apenas indica um caminho possível. Precisaríamos, antes de tudo de definir o que é a dialética platônica, isto despenderia muito mais tempo e um trabalho bem árduo, mas isto é um projeto futuro. 


\section{Bibliografia}

PLATÃO, Tutte le opere. Trad. it. Giovanni Caccia. Roma: Grandi Tascabili Economici Newton, 1997.

Apologie de Socrate. Traduction, introduction et notes par Luc Brisson. Paris: GF Flammarion, 1997.

. Carmides. Traduction, introduction et notes par Louis-André Dorion. Paris: GF Flammarion, 2004.

. Criton. Traduction, introduction et notes par Luc Brisson. Paris: GF

Flammarion, 1997.

. Euthyphron. Traduction, introduction et notes par Louis-André Dorion.

Paris: GF Flammarion, 1997.

Lachès. Traduction, introduction et notes par Louis-André Dorion. Paris:

GF Flammarion, 1997.

. Mênon. Trad. Br. Maura Iglésias. Rio de Janeiro: Ed. PUC-Rio; Loyola, 2001.

_. "Premiers Dialogues". Traduction, notices et notes par Émile Chambry. Paris: GF Flammarion, 1967.

. Protagoras. Traduction, introduction et notes par Frédérique Ildefonse.

Paris: GF Flammarion, 1997.

República. Tradução, introdução e notas de Maria Helena da Rocha

Pereira. Lisboa: Fundação Calouste Gulbenkian, $8^{\mathrm{a}}$ ed.,1996.

Aristóteles, Metafísica de Aristóteles. Edición Trilingüe por Valetín García Yebra. Madrid: Editorial Gredos, 1990.

Crombie, I. M., “Socratic Definition”. In Plato’s Meno in Focus, London and New York: Routledge. 
Devereux, D., "The Unity of the Virtues in Plato's Protagoras and Laches", in The Philosophical Review, Vol. 101, № 4, 1992.

Dixsaut, M., Métamorfoses de la Dialectique dans les Dialogues de Platon. Paris: Vrin, 2001.

Ferejohn, M. T., "The Unity of Virtue and the objects of Socratic Inquiry". In Socrates and His Contemporaries, New York, 1995.

Fine, G., On Ideas. Oxford, 1993. , Plato 1: Metaphysics and Epistemology, "Introduction". Orford University Press. , "The One Over Many", in Philosophical Review 89, 1980.

Goldschmidt, V., "Os Diálogos de Platão: estrutura e método dialético". Trad. Br. Dion Davi Macedo. São Paulo: Edições Loyola, 2002.

Hall, R., "Dialectic". In the Encyclopedia of Philosophy, New York: Macmillan Publishing Co., Inc. \& The Free Press, 1967.

Irwin, T., Plato’s Ethics. New York: Oxford University Press, 1995.

Penner, T., "The Unity of Virtue”, in Philosophical Review 82, 1973.

Robinson, R., "Plato's Earlier Dialectic". New York: Clarendon Press, 1941.

Vlastos, G., "Socrates' Disavowial of Knowledge" (1985). In Plato 1: Metaphysics and Epistemology, Orford University Press.

. "The Socratic Elenchus" (1983). In Plato 1: Metaphysics and Epistemology, Orford University Press.

_ "The unity of virtues in the Protágoras", in Platonic Studies. Princeton: Princeton University Press, 1971.

Zingano, M. "Vertu et Savoir chez Socrate", 2004 (mimeo). 